\title{
New Insights into the Biology of Schizophrenia through the Mechanism of Action of Clozapine
}

Nicoletta Brunello, Ph.D., Claudio Masotto, Ph.D., Luca Steardo, M.D., Ph.D., Rudolf Markstein, Ph.D., and Giorgio Racagni, Ph.D.,

\begin{abstract}
Many studies have detected in the brain of schizophrenic patients various morphological and structural abnormalities in various regions and in particular in the cortical and limbic areas. These abnormalities might in part result from neurodevelopmental disturbances suggesting that schizophrenia might have organic causes. These abnormalities may be the primary event in schizophrenia and be responsible for altered dopaminergic, but not only dopaminergic, neurotransmission in these regions. If schizophrenia is in some way strictly related to brain morphological abnormalities it becomes hard to believe that a curative treatment will ever be possible. Considering this scenario, treatment of schizophrenia will be restricted to symptomatic and preventive therapy and therefore, more effective and better tolerated antipsychotics are necessary. The widely used classical antipsychotic drugs present some disadvantages. They do not improve all symptoms of schizophrenia, are not effective in all patients, produce a number of unpleasant and serious, and partly irreversible, motor side effects. The atypical antipsychotic clozapine constitutes a major advance in particular for patients not responding to conventional neuroleptics. To explain the unique therapeutic effect of clozapine many hypotheses have been proposed. Most of the explanations given so far assume that the $D_{2}$ blockade is the basis for the antipsychotic activity of clozapine and that the difference in respect to other antipsychotics is due to the contribution of other
\end{abstract}

receptor interactions. Considering the dopaminergic receptor, in particular the recently discovered $\mathrm{D}_{4}$ receptor subtype, it has been observed that even if several classical neuroleptics exhibit high affinity to the $D_{4}$ receptor, clozapine is more selective for this subtype compared to $\mathrm{D}_{2}$ receptors. Moreover clozapine, differently from all other conventional neuroleptics, is a mixed but weak $D_{1} / D_{2}$ antagonist. This observation has prompted speculation that the synergism between $D_{1}$ and $D_{2}$ receptors might allow antipsychotic effects to be achieved below the threshold for unwanted motor side effects. Probably the $D_{1}$ antagonistic activity exerted by clozapine at low doses enhances preferentially the extracellular concentration of dopamine in specific areas of the brain, such as the prefrontal cortex, where a dopaminergic hypoactivity has been suggested to be in part responsible for negative symptoms of schizophrenia. The clozapine enhancement of dopaminergic activity in this brain area might explain its efficacy against schizophrenia negative symptoms. However, it cannot be excluded that the affinities displayed by clozapine for other nondopaminergic receptors also contribute to its unique therapeutic profile. The various hypotheses mentioned in this review need to be further validated or disproved. The only way to do that is developing new drugs where the postulated mechanistic profile is specifically realized and to clinically test these compounds.

[Neuropsychopharmacology 13:177-213, 1995]

KEY WORDS: Schizophrenia; Clozapine; Atypical antipsychotic; Dopamine; Serotonin; Neuroleptic

From the Centre of Neuropharmacology (NB, CM, GR), University of Milan, Italy; the Department of Pharmaceutical Sciences (NB), University of Modena, Italy; the Institute of Pharmacology (LS), Medical School, University of Bari, Italy; and Preclinical Research (RM), Sandoz Pharma AG, Basel, Switzerland.
Address correspondence to: Giorgio Racagni, Centre of Neuropharmacology, Institute of Pharmacological Sciences, University of Milan, Via Balzaretti, 9, 20133-Milan, Italy.

Received April 28, 1994; revised February 8, 1995; accepted March 29, 1995. 


\section{BIOLOGICAL ASPECTS OF SCHIZOPHRENIA}

\subsection{Neuroanatomy and Pathology}

Brains of schizophrenic patients have been the subject of many different studies aimed at uncovering specific alterations that correlate with the development and progression of this illness. One of the most consistently observed alterations is a mild degree of enlargement of the cerebral ventricles (Johnstone et al. 1976; Weinberger et al. 1979; Kelsoe et al. 1988; Suddath et al. 1989; Brown et al. 1986). However, such abnormalities are not present in all patients suffering from schizophrenia. Whereas several computed tomography (CT) studies have confirmed ventricular enlargements of cerebral ventricles in schizophrenic patients (Weinberger et al. 1982; Schulz et al. 1983; Nyback et al. 1982), others were unable to detect such changes (Benes et al. 1992; Owens et al. 1985; Scottish Schizophrenia Research Group 1989; Rubin et al. 1993; Heckers et al. 1990). However, as only a few studies have been made on first-admission patients, effects of medication, hospitalization, and duration of the illness on brain-structure findings cannot be excluded. Thus, the question of whether ventricular enlargement is already present at the first episode of the disease (and consequently is not the result of antipsychotic treatment) still remains unsolved. In any case the presence of ventricular enlargement is indicative for a tissue loss in the brain of schizophrenic patients. Recent studies using magnetic resonance imaging (MRI) have demonstrated that the magnitude of the ventricular enlargement correlates with the volume reduction of temporal lobe gray matter, especially in the region containing the amygdala and hippocampus (Suddath et al. 1989).

Among the structural abnormalities found in the brain of schizophrenics, those in the medial temporal lobe and particularly the volume reduction of the amygdala-hippocampal formation are the most consistent and have attracted the greatest interest (Wolf et al. 1993). These findings have recently been confirmed in 15 sets of monozygotic twins discordant for schizophrenia (Suddath et al. 1990). The use of discordant 'monozygotic twins allows for the question of whether observed anatomic alterations are a real pathologic phenomenon or a random finding in schizophrenia to be addressed. Significant differences between affected and unaffected twins are present in the lateral ventricles, third ventricle, temporal lobe (including the anterior hippocampus), and in the total volume of the gray matter in the left temporal lobe (Suddath et al. 1990). These differences were not observed in normal pairs of twins and are in agreement with the findings of previous studies that reported enlarged lateral and third ventricles (Johnstone et al. 1976; Weinberger et al. 1979; Kelsoe et al. 1988; Suddath et al. 1989; Brown et al. 1986) and smaller hippocampi (Bogerts et al. 1985) in schizophrenic patients.

The fact that structural differences are present in the central nervous system (CNS) of affected monozygotic twins compared to unaffected twins strongly suggests that the neuropathologic process underlying schizophrenia is at least partly not genetic. No correlations were observed between the presence of these brain alterations and the extent of neuroleptic exposure or the duration of the illness in the patients (Weinberger et al. 1979; Shelton and Weinberger 1986; Kelsoe et al. 1988; Golden et al. 1981; Frangos and Athanassenas 1982; Nasrallah et al. 1982; Schulsinger 1984; Williams et al. 1985), thus ruling out the possibility that these brain alterations are due to nonspecific aspects of schizophrenia or its treatment (Suddath et al. 1990). Traditional neuropathologic studies of the brains of schizophrenic patients have demonstrated changes within the cortex, basal ganglia, limbic system, and brainstem. Cortex and amygdala-hippocampal formation are the regions where a number of studies consistently found alterations in schizophrenia. In the cortex, especially in the prefrontal region, a trend toward a reduced cell number and density (Benes et al. 1986; Colon 1972) and densely staining, thickened dendrites and axons (Tatetsu 1964) has been observed. Analogous findings of a volume reduction of the hippocampus (Heckers et al. 1991; Bogerts et al. 1985; Falkai and Bogerts 1986; Jeste and Lohr 1989; Bogerts et al. 1990a, b; DeLisi et al. 1988), a certain disarray of the dendrites of pyramidal cells in the hippocampus (Scheibel and Kovelman 1981; Kovelman and Scheibel 1984), and an altered development of the superficial layers of the entorhinal cortex (Beckmann and Jakob 1991; Jakob and Beckmann 1986) have been found, which suggest an alteration of early brain development. The entorhinal cortex forms a major part of the parahippocampal gyrus in humans and functions as an interface that processes information exchange between the hippocampus and cortical and subcortical areas (Jones 1993). There is evidence for early pathologic changes in the entorhinal cortex in various disease states including Alzheimer's disease. In the entorhinal cortex of schizophrenic patients, alteration of normal laminar patterns and a certain degree of neuronal disorganization especially in the more superficial layers have been detected (Jakob and Beckmann 1986; Beckmann and Jakob 1991; Falkai et al. 1988; Arnold et al. 1991a). These cytoarchitectural abnormalities have been attributed to a particular vulnerability and disturbance in fetal nerve cell migration, probably originating in the second trimester of pregnancy (Jakob and Beckmann 1986; Beckmann and Jakob 1991; Falkai et al. 1988; Arnold et al. 1991a). Considering the numerous interconnections of the entorhinal cortex with the hippocampus and wide- 
spread cortical fields, it has been hypothesized that an alteration in the early development of the entorhinal cortex might generate abnormalities in cortical development and consequently functionality (Weinberger 1987). Recently, the study of two microtubule-associated cytoskeletal proteins (MAP2 and MAP5) in the hippocampal formation has shown that their expression is reduced specifically in the entorhinal cortex and subiculum of schizophrenic patients compared to controls (Arnold et al. 1991b). These observations might explain the cytoarchitectural alterations observed in this region. Although these alterations are not easy to interpret, it is important to note that their localization in structures that play an important role in cognitive processes correlates well with the profound alterations observed in schizophrenic patients.

In the last few years, increasing attention has been paid to the deficits in various cognitive functions, especially attention, memory, and executive functions that occur in schizophrenia (Levin et al. 1989). These deficits may be the result of the pathologic alteration and dysfunction within the neocortical-limbic neuronal network of schizophrenic patients. Recent studies of identical twins discordant for schizophrenia have shown that there is a correlation between the withinpair difference in left anterior hippocampal volume and the difference in the same pair during activation of the dorsolateral prefrontal cortex, which occur during performance of a cognitive task (Weinberger et al. 1986; Weinberger et al. 1988; Rubin et al. 1991; Berman et al. 1991). In the affected twin compared to his or her cotwin, a smaller hippocampal volume corresponds to a low activation of the prefrontal cortex during the performance of the cognitive test. This finding reinforces the hypothesis that in schizophrenic patients dysfunctions of the neocortical-limbic connectivity are present.

A dysfunctional dopaminergic activity of the dorsolateral prefrontal cortex has been suggested to be responsible for the prefrontal hypofunction observed in schizophrenic patients during the performance of cognitive tasks requiring working memory such as the Wisconsin Card Sorting Test (Weinberger et al. 1988). However, more recent studies suggest that this dysfunction may not be the cause but the result of prefrontal hypoactivity. Prefrontal neurons, probably glutamatergic, form synapses with dopaminergic neurons that project to the prefrontal cortex (Sesack et al. 1989; Sesack and Pickel 1990; Daniel et al. 1991). A diminished activity of these glutamatergic neurons might decrease the excitability of dopaminergic afferents. Alternatively prefrontal hypoactivity could be caused by a diminished function of glutamatergic neurons projecting from anterior hippocampus to dopaminergic neurons in the ventral tegmental area (Wallas and Fonnum 1980 ), which would then result in hypoactivity of prefrontal dopaminergic afferents (Simon et al. 1988; Lipska et al. 1992).

In line with these hypotheses are recent results proving the main role played by the hippocampus in the regulation of mesolimbic dopaminergic system (Lipska et al. 1992; Sesack and Pickel 1990; Van Groen and Wyss 1990; Weinberger 1988). In particular it has been demonstrated that in rats specific bilateral lesions of the ventral hippocampus, with ibotenic acid, produce differential changes in cortical (medial prefrontal cortex) and subcortical limbic (nucleus accumbens) dopaminergic activity (Lipska et al. 1992). The reduced dopamine turnover in medial prefrontal cortex is accompanied by an increased dopamine concentration in nucleus accumbens.

In summary, preclinical and clinical evidence strongly suggests that in schizophrenia structural changes of the hippocampus are present (Suddath et al. 1990; Heckers et al. 1991; Bogerts et al. 1985; Falkai and Bogerts 1986; Jeste and Lohr 1989; Bogerts et al. 1990a, b; DeLisi et al. 1988; Scheibel and Kovelman 1981; Kovelman and Scheibel 1984; Beckmann and Jakob 1991; Jakob and Beckmann 1986). These changes might be partially responsible for (1) the reduced cortical dopaminergic activity and consequently the prefrontal dysfunction (Daniel et al. 1991; Weinberger et al. 1988 ) and (2) the disorganization of dopaminergic systems in the striato-limbic system.

\subsection{Neurochemistry}

1.2.1. Dopamine Hypothesis. The most widely accepted hypothesis concerning the neurochemical abnormality present in schizophrenia is the dopamine hypothesis, which states that the cardinal manifestations of this mental disease are the result of an increased dopaminergic activity in certain brain areas. This interpretation gains support from the observations that neuroleptics block central dopamine receptors, whereas psychotic symptoms can be induced by drugs which enhance dopaminergic activity such as amphetamine (Seeman et al. 1976).

At the beginning of the 1970s the existence of only one type of receptor was not sufficient to explain the multiple actions exerted by dopamine. Subsequently, on the basis of biochemical and pharmacologic observations, brain dopamine receptors were divided into two types, called $D_{1}$ and $D_{2}$. In the last few years the advances in the molecular biology of the dopamine receptor system led to the identification and characterization of at least five distinct subtypes of dopamine receptors and the existence of further dopamine receptor subtypes cannot be ruled out.

Two out of the five cloned dopamine receptors exhibit the functional and pharmacologic properties characteristic of the classical $D_{1}$ receptor, whereas the other 
three receptor types possess the characteristics of the $\mathrm{D}_{2}$ receptor. The five dopamine receptors are now divided into two families: the $D_{1}$ family, which includes the $D_{1}$ and $D_{5}$, and the $D_{2}$ family, which includes the $\mathrm{D}_{2}, \mathrm{D}_{3}$, and $\mathrm{D}_{4}$ receptors.

THE $D_{1}$ Receptor. The $\mathrm{D}_{1}$ receptor, independently cloned in 1990 by four different groups of researchers (Dearry et al. 1990; Monsma et al. 1990; Sunahara et al. 1990; Zhou et al. 1990), is a glycoprotein with seven transmembrane domains, whereby the N-terminus is localized to the extracellular surface and the C-terminus projects into the cytosol. These characteristics are common to all the G-protein-coupled receptors cloned up to now (Strader et al. 1989; Dohlman et al. 1991). The small third cytoplasmatic loop and a long C-terminus present in $\mathrm{D}_{1}$ receptors are characteristics in common with receptors that are coupled to the Gs protein and stimulate adenylate cyclase activity, such as the $\beta$-adrenergic receptors (Strader et al. 1989; Dohlman et al. 1991).

Using northern blot analysis and in situ hybridization histochemistry the distribution of mRNA encoding for $\mathrm{D}_{1}$ receptors in the brain has been determined (Dearry et al. 1990; Monsma et al. 1990; Sunahara et al. 1990; Zhou et al. 1990; Gerfen et al. 1990; Fremeau et al. 1991; Le Moine et al. 1991; Mengod et al. 1991; Weiner et al. 1991). $D_{1}$ receptor mRNA distribution correlates well with the localization of $\mathrm{D}_{1}$ binding sites and the regional distribution of dopamine-activated adenylate cyclase. The highest expression of $D_{1}$ receptor mRNA has been detected in the caudate putamen, nucleus accumbens, and olfactory tubercle, whereas a lower expression has been found in the cerebral cortex, limbic system, hypothalamus and thalamus.

THE $\mathrm{D}_{5}$ RECEPTOR. The second receptor belonging to the $D_{1}$ family to be isolated and cloned was the $D_{5}$ receptor (Grandy et al. 1991; Sunahara et al. 1991; Weinshank et al. 1991). Like the $D_{1}$ receptor it possesses seven transmembrane domains. Considering the transmembrane domain region between the $D_{1}$ and $D_{5}$ receptors, an homology of about $80 \%$ has been observed. Radioligand binding studies have shown that various dopaminergic agonists and antagonists display similar affinities for the $D_{1}$ and $D_{5}$ receptors, the only exception being dopamine, which is 5 to 10 times more potent at $D_{5}$ than at $D_{1}$ receptors. With regard to stimulation of adenylate cyclase activity no pharmacologic differences were observed between $D_{1}$ and $D_{5}$ receptors (Grandy et al. 1991; Sunahara et al. 1991; Weinshank et al. 1991).

Northern blot analysis has demonstrated the presence of $D_{5}$ receptor mRNA in the lateral mammillary nuclei, the parafascicular nuclei of the thalamus, and several layers of the hippocampus (Tiberi et al. 1991; Meador-Woodruff et al. 1992). The $\mathrm{D}_{5}$ receptor mRNA seems not to be present in areas where the $D_{1}$ recep- tor mRNA is present, such as striatum, nucleus accumbens, or olfactory tubercle (Tiberi et al. 1991; MeadorWoodruff et al. 1992). Hence, the brain distribution of the $\mathrm{D}_{5}$ receptor mRNA, compared to that of the $\mathrm{D}_{1}$ receptor, is more restricted.

THE $D_{2}$ RECEPTOR. The $D_{2}$ receptor was the first member of this family to be cloned (Bunzow et al. 1988). The $D_{2}$ receptor is like the $D_{1}$ and $D_{5}$ receptor, a glycoprotein characterized by seven transmembrane regions. Compared to $D_{1}$ and $D_{5}$ receptors, the $D_{2}$ receptor possesses a shorter $C$-terminus and a larger third cytoplasmatic loop. These two properties are common to many G-protein-linked receptors that inhibit adenylate cyclase activity.

Northern blot analysis and in situ hybridization histochemistry have been used to study the distribution of mRNA encoding $D_{2}$ receptors in the brain (Bunzow et al. 1988; Dal Toso et al. 1989; Meador-Woodruff et al. 1989; Mengod et al. 1989; Najlerahim et al. 1989; Weiner and Brann 1989; Mansour et al. 1990; Stormann et al. 1990; Weiner et al. 1990). The results obtained correlate well with previous radioligand receptor studies of $D_{2}$ receptor distribution. The caudate putamen, nucleus accumbens, and olfactory tubercle are the areas richest in $\mathrm{D}_{2}$ receptor $m R N A$. In the striatum a certain percentage of medium- and large-sized cells appears to express $D_{2}$ receptor mRNA (Gerfen et al. 1990; Weiner et al. 1990; Le Moine et al. 1990). Receptor mRNA has also been detected in the dopaminergic cell bodies in the substantia nigra pars compacta and ventral tegmental area, suggesting a possible presynaptic role for $\mathrm{D}_{2}$ receptors.

$D_{2}$ receptors have been shown to exist in two different protein isoforms, which are derived from the same gene by alternative mRNA splicing and differ in length by 29 amino acids (Dal Toso et al. 1989; Eidne et al. 1989; Giros et al. 1989; Grandy et al. 1989; Monsma et al. 1989; Selbie et al. 1989; Chio et al. 1990; Miller et al. 1990; O'Dowd et al. 1990; O'Malley et al. 1990; Rao et al. 1990; Gandelman et al. 1991; Mack et al. 1991; Montmayeur et al. 1991). The two isoforms, designated as $D_{2 s}$ (for short) and $D_{2 l}$ (for long), have been shown to occur in human, rat, bovine, and mouse brain tissue. No pharmacologic differences have been found between the two isoforms; both isoforms are able to inhibit adenylate cyclase activity (Dal Toso et al. 1989), activate $\mathrm{K}^{+}$channels, potentiate arachidonic acid release (Kanterman et al. 1991), undergo agonist-induced desensitization in a similar way, and exhibit age-related variation in rat brain areas (Della Vedova et al. 1992).

THE $D_{3}$ RECEPTOR. This receptor shows a membrane topography and an amino acid sequence similar to that of the $D_{2}$ receptor (Sokoloff et al. 1990, 1992b). The human $D_{3}$ receptor, which has been recently identified (Giros et al. 1990), has a shorter third cytoplasmic loop compared to rat $\mathrm{D}_{3}$ receptors; however, 
the homology between the two receptors is extremely high.

The brain content of $D_{3}$ receptor mRNA is lower than that of the $D_{2}$ receptor. It is mainly localized in the nucleus accumbens, the islands of Calleja, the bed nucleus of the stria terminalis, and other limbic areas including the olfactory tubercle, hippocampus, mammillary nuclei, and the hypothalamus (Sokoloff et al. 1990; Bouthenet et al. 1991). This preferential limbic localization of the $D_{3}$ receptor suggests that it may be involved in the control of emotional and cognitive functions and that a specific antagonist of this receptor may be a useful antipsychotic drug.

THE $\mathrm{D}_{4}$ RECEPTOR. This receptor is the most recent dopamine receptor cloned to date (Van Tol et al. 1991). Like the $D_{2}$ and $D_{3}$ receptor, it has a seven transmembrane region with a large third cytoplasmic loop and a short C-terminus. The overall amino acids sequence homology of the $D_{4}$ receptor with the $D_{2}$ and $D_{3}$ receptors is about $40 \%$. Radioligand binding studies show similar pharmacologic properties of $D_{2}, D_{3}$, and $D_{4}$ receptors. However, drugs exist that are able to differentiate between these receptors. For instance, clozapine exhibits a 10 times higher and raclopride at least a 1,000 times lower affinity for the $\mathrm{D}_{4}$ receptor compared to the $D_{2}$ receptor (Seeman and Van Tol 1994).

Recently polymorphic variants of the dopamine $\mathrm{D}_{4}$ receptor have been detected. These variants differ by inserts consisting of 16 amino acids, which are repeated up to 10-fold in the third cytoplasmic loop (Van Tol et al. 1992). More recent data indicate that the variants vary not only in the number of inserts but that variations also exist within the sequence of the inserts (Lichter et al. 1993). Hence, $D_{4}$-like receptors seem to be one of the most variable functional proteins currently known (Strange 1994). The fact that the variations occur in the third loop, which is considered to be the coupling site with G-proteins, suggests that differences in G-protein interactions may exist among the different forms. In fact, different binding properties to some of the variants have been reported for clozapine (Van Tol et al. 1992).

The brain distribution of $\mathrm{D}_{4}$ receptors has not been well investigated, being hampered by the lack of potent and selective ligands and the fact that the density of the $D_{4}$ receptor is much lower than that of the $D_{2}$ receptor. Furthermore, the existence of multiple variants makes detection as well as distinction of these multiple forms even more difficult. Preliminary results from studies using in situ hybridization techniques suggest that the regional distribution of $\mathrm{D}_{4}$ receptor mRNA in the brain differs from that of the other dopamine receptors. The highest levels of $D_{4}$ receptor mRNA has been found in the frontal cortex, midbrain, amygdala, hypothalamus, and medulla, whereas a lower level is present in the striatum and olfactory tubercle (Mansour et al. 1991; Meador-Woodruff et al. 1991; Van Tol et al. 1991).

DOPAMINERGIC MECHANISMS: BASIC AND CLINICAL ASPECTS. Most of the initial studies that investigated the role of the dopaminergic system in schizophrenia focused on dopamine and its metabolite levels in the cerebrospinal fluid and in specific brain areas of deceased schizophrenic subjects compared to controls (see review by Heritch 1990). Although the results obtained from these studies are very variable, they indicate that dopamine turnover in schizophrenia may be both reduced and dysregulated. It has been suggested that a reduced dopamine turnover is associated with a diminished dopamine release, which consequently induces a postsynaptic supersensitivity. The possible presence of an increased number of dopaminergic receptors in schizophrenic brain is still the subject of intense investigation. Indeed many studies have indicated that in postmortem schizophrenia brain tissue, especially in the caudate, putamen and nucleus accumbens, dopamine $D_{2}$ and $D_{2}$-like receptor density is elevated (Owen et al. 1978; Lee et al. 1978; Seeman et al. 1987; Seeman 1992). Unfortunately this finding may be affected by the neuroleptic treatment received by most of the patients. Interesting results have come from a recent study in which the density of dopamine receptors of a $\mathrm{D}_{4}$ subtype has been measured in postmortem striata from patients who died with schizophrenia, Huntington's chorea, or Alzheimer's disease (Seeman et al. 1993; Seeman and Van Tol 1994). In this study, the number of $D_{4}$ sites was calculated from the difference between the number of binding sites occupied by $\left[{ }^{3} \mathrm{H}\right]$-emonapride, which binds to $\mathrm{D}_{2}, \mathrm{D}_{3}$, and $\mathrm{D}_{4}$ receptors, and those occupied by $\left[{ }^{3} \mathrm{H}\right]$-raclopride, which binds to $D_{2}$ and $D_{3}$ but not to $D_{4}$ receptors. The major finding of this study was that the density of $\mathrm{D}_{4}$-like receptors is elevated six-fold in the striata of schizophrenic patients, but not in the striata of patients who died with Alzheimer's disease or Huntington's chorea (Seeman et al. 1993; Seeman and Van Tol 1994). In the brains of normal individuals or Alzheimer's disease patients, the number of $D_{4}$ receptors represents only a relatively small percentage of the total number of dopamine receptors. By contrast, in schizophrenic patients the number of $D_{4}$ receptors constitutes now approximately $40 \%$ of the total number of $\mathrm{D}_{2}$-like receptors. Because the number of $\mathrm{D}_{4}$ receptors is not enhanced in the striata of Alzheimer's patients who have received neuroleptics, the increased density of $\mathrm{D}_{4}$-like receptors is probably a brain abnormality specific to schizophrenia and not caused by neuroleptic treatment (Seeman et al. 1993).

Further support for the previous findings comes from binding experiments in which the competition between clozapine and $\left[{ }^{3} \mathrm{H}\right]$-spiperone in the striatum of controls and schizophrenic patients was measured. In 
control striatum, clozapine occupies $\mathrm{D}_{2}$ receptors but not dopamine $\mathrm{D}_{4}$ receptors, whereas in schizophrenics where the density of dopamine $D_{4}$ receptors is enhanced, clozapine occupies both $\mathrm{D}_{2}$ and $\mathrm{D}_{4}$ receptors (Seeman et al. 1993).

The increased number of dopamine $\mathrm{D}_{4}$ receptors in the brain of schizophrenics could conceivably account for the unique antipsychotic effect of clozapine and may in part invalidate the therapeutic significance attributed to $D_{2}$ receptor blockade exerted by neuroleptics. Moreover, the recent identification of polymorphic variants of the $\mathrm{D}_{4}$ receptor in the human population, which bind clozapine with different affinities, may in part explain different susceptibilities to schizophrenia and response to neuroleptic treatment (Van Tol et al. 1992).

Another biochemical abnormality detected in the striata of schizophrenics concerns the effect of guanine nucleotides on dopamine receptor affinity. Guanine nucleotides normally enhance $\left[{ }^{3} \mathrm{H}\right]$-raclopride binding in brain preparations of controls and patients who died with Huntington's chorea or Alzheimer's disease but not in brain preparations of schizophrenic patients (Seeman et al. 1993). Guanine nucleotides produce an even higher increase in the density of $\left[{ }^{3} \mathrm{H}\right]-\mathrm{SCH}-23390$ binding sites (dopamine $D_{1}$ and $D_{5}$ receptors) in the striata of controls, whereas a decrease has been observed in the striata of schizophrenics (Seeman et al. 1993). These observations suggest the existence of an abnormal interaction between dopamine receptors and G-proteins in the brains of schizophrenics (Seeman et al. 1993; Iversen 1993). However, as such an insensitivity to guanine nucleotide has been observed also in the brain of patients who died with Parkinson's disease, it may not be specific to schizophrenia. In any case, if the nucleotide insensitivity, as well as the increased $\mathrm{D}_{4}$ receptor density, is related to schizophrenic disorders, it is reasonable to assume that such changes are present in other neurologic and psychiatric disorders with a schizophrenic component.

It has been shown that in the control of psychomotor and physiologic mechanisms, $D_{1}$ and $D_{2}$ receptors can either enhance or oppose each other's action (Gershanik et al. 1983; Walters et al. 1987; Rosengarten et al. 1983; Stoof and Kebabian 1981; Clark and White 1987). Little evidence is available concerning the possible molecular mechanism explaining these $D_{1}-D_{2}$ receptor interactions. $D_{1}-D_{2}$ interactions have been established by radioreceptor studies in postmortem homogenized tissue of different brain areas of experimental animals and humans. Results obtained, from binding studies, in postmortem striata of controls and schizophrenic patients suggest that the link between these two receptors is defective in over half of the schizophrenic patients (Seeman et al. 1989). Because these data were obtained before the discovery of other dopaminergic receptors, they need to be reevaluated in light of the new situation. However, these findings suggest that in the brain of schizophrenics the interaction processes between the different dopamine receptor subtypes is disturbed.

In the last few years, interesting neurochemical findings have been obtained in psychiatric disorders by the use of brain imaging techniques (Andreasen 1988). Among these techniques, the studies performed using positron emission tomography (PET) have analyzed the dopamine receptor subtypes in living human brain in relation not only to schizophrenia but also to its neuroleptic treatment (Sedvall 1992). Experiments in which $\left[{ }^{11} \mathrm{C}\right]$-raclopride and $\left[{ }^{11} \mathrm{C}\right]-\mathrm{N}$-methylspiperone have been used to visualize dopamine receptors have shown either an increase or no change in $D_{2}$ dopamine receptor density in major basal ganglia of drug-naive schizophrenic patients compared to controls (Farde et al. 1990; Sedvall 1992, 1993). These discrepancies may be explained by considering the existence of subtypes of dopamine receptors, the different affinity of the ligands for these dopamine receptor subtypes, and the data obtained in the recent work of Seeman and co-workers (Seeman et al. 1993) previously reported.

Because dopamine $\mathrm{D}_{1}$ receptor antagonists produce behavioral effects in experimental animals similar to antipsychotic drugs, PET studies have been performed using a specific ligand for the $D_{1}$ receptor such as $\mathrm{SCH}-23390$ and $\mathrm{SCH}-39166$. These studies demonstrate that the total number of $D_{1}$ receptors in the basal ganglia does not differ between controls and drug-naive schizophrenic patients (Sedvall 1992, 1993).

Certainly further studies utilizing brain imaging techniques are necessary to elucidate, from a neurochemical point of view, the different aspects of involvement of brain dopaminergic system in schizophrenia.

\subsubsection{Nondopaminergic Mechanisms Relevant to Schizophrenia}

SEROTONIN. In recent years there has been increasing interest in a possible role of serotonin in the pathogenesis of schizophrenia. This is due to the fact that several recent studies have provided evidence supporting a role of serotonin in schizophrenia (Kahn and Davidson 1993). The efficacy of serotonin (5-HT) antagonists, such as ritanserin, in ameliorating some schizophrenic (negative) symptoms and, when administered with haloperidol, in diminishing extrapyramidal side effects (Gelders 1989), suggested the usefulness of 5-HT receptor blockade in the treatment of schizophrenia. In particular these observations indicated a possible role of 5-HT in negative symptoms in schizophrenia and in decreasing the extrapyramidal side effects induced by blockade of dopamine receptors (Leysen et al. 1993b). A further stimulus to the study of 5-HT in schizophrenia comes from the observation that clozapine is a po- 
tent antagonist of $5-\mathrm{HT}_{2 \mathrm{~A}}$ and $5-\mathrm{HT}_{2 \mathrm{C}}$ receptors but a weak antagonist at $\mathrm{D}_{2}$ receptors (Canton et al. 1990; Meltzer 1989).

In view of the close anatomic connections (Tork 1991) and the functional interactions (Kelland et al. 1990) between the serotoninergic and dopaminergic systems, it is plausible to suggest that in schizophrenic patients dysregulation of dopaminergic systems is accompanied by altered functionality of the serotoninergic system. It is possible that in some schizophrenic patients an alteration of dopaminergic activities predominates, whereas in others the dysfunction concerns mainly the serotoninergic system.

Most of the initial findings related to 5-HT and schizophrenia in postmortem brains have not been confirmed (Crow et al. 1979; Joseph et al. 1979; Winblad et al. 1979; Owen et al. 1981; MacKay et al. 1982; Reynolds et al. 1983; Korpi et al. 1986; Mita et al. 1986; Toru et al. 1988; Arora and Meltzer 1991). Two observations that could be reproduced were enhanced $5-\mathrm{HT}$ concentrations in the putamen (Farley et al. 1980; Korpi et al. 1986; Toru et al. 1988) and in the globus pallidus (Winblad et al. 1979; Korpi et al. 1986) of schizophrenics. Studies in which the number of 5-HT uptake sites has been measured have indicated a decrease in many brain regions including the dorsolateral prefrontal cortex, frontal lobe, and anterior cingulate. An increase in the number of 5-HT uptake sites has been observed in the dorsal and ventral striatum of schizophrenic patients (Joyce et al. 1993; Joyce 1993). This result is in agreement with the finding that the levels of 5-HT and/or its metabolite 5-hydroxyindolacetic acid (5-HIAA) are enhanced in these brain regions of schizophrenic patients (Winblad et al. 1979; Farley et al. 1980). Hence, the previous findings are compatible with the view that in the schizophrenic brain the serotoninergic innervation of the striatum is increased (Joyce et al. 1992).

Many studies have focused on 5-HT receptors in the schizophrenic brain. However, some results are inconsistent and need to be reconfirmed. Among the observations on 5-HT receptors, those indicating a reduction in particular of the $5-\mathrm{HT}_{2 \mathrm{~A}}$ receptor subtypes in prefrontal cortex of schizophrenic patients are the most interesting (Mita et al. 1986; Arora and Meltzer 1991; Hashimoto et al. 1993). This reduction is accompanied by an increase in $5-\mathrm{HT}_{1 \mathrm{~A}}$ receptors (Hashimoto et al. 1991; Hashimoto et al. 1993), and as $5 \mathrm{HT}_{2 \mathrm{~A}}$ and the $5-\mathrm{HT}_{1 \mathrm{~A}}$ receptors are interactive (Uphouse et al. 1994), the two changes may be related (Hashimoto et al. 1993).

The reported neurochemical findings suggest that in the brain of schizophrenics the serotoninergic innervation is decreased in the cortex but augmented in the striatum. It has been speculated that the simultaneous hypoinnervation and hyperinnervation results from specific damage of the dorsal raphe, which may occur during the period of development of serotoninergic projections (i.e., the second trimester of gestation) (Joyce et al. 1993). Thus, the alteration of the neuronal structure present in the temporal lobe of schizophrenic patients may well be the result of abnormal neuronal development.

NEUROTENSIN. A number of studies has focused on the possible involvement of neuropeptides in the pathogenesis of schizophrenia. Among these peptides neurotensin (NT) has attracted considerable interest. NT is an endogenous tridecapeptide found in the CNS (Stowe and Nemeroff 1993; Kitabgi 1989; Levant and Nemeroff 1988) as well as in the periphery (Leeman and Carraway 1982). In the CNS, NT is heterogeneously distributed and associated with dopamine neurons in the medial prefrontal cortex, the mesencephalon, and the hypothalamus (Uhl and Snyder 1977). In particular, NT is closely associated with the mesolimbic, mesocorti$\mathrm{cal}$, and nigrostriatal dopaminergic systems (see review Levant and Nemeroff 1988). High levels of NT have been found in regions containing dopaminergic neuronal perikarya and dopaminergic terminals (Griffiths et al. 1984).

Clinical studies have demonstrated a diminished concentration of NT in the cerebrospinal fluid of schizophrenic patients compared to controls (Garver et al. 1991; Lindström et al. 1988; Widerlov et al. 1982). This lower level is not due to pharmacologic treatment and seems specific, because it has not been detected in major depression, bulimia, and premenstrual syndrome (Manberg et al. 1983). In schizophrenic subjects the decrease of NT in the cerebrospinal fluid has been found to correlate positively with diminished locomotor activity (Lindström et al. 1988), augmented hallucinations-delusions, thought disorders, and disorganized behavior (Garver et al. 1991). Postmortem studies in schizophrenic patients indicate that the concentration of NT is increased in one frontal cortical area, the Brodmann's area (BA) 32, but not in other frontal cortical areas such as BA 12 or 24 . No changes have been found in the nucleus accumbens, hypothalamus, and striatum (Nemeroff et al. 1983).

SIGMA RECEPTORS. The fact that some neuroleptics exhibit a high affinity to sigma receptor binding sites has attracted considerable interest. It has been proposed that psychotomimetic effects observed with certain opiates and related drugs are due to their effect on these receptors (Martin et al. 1976). These psychotomimetic effects resemble some of the symptoms observed in schizophrenic patients. Therefore, it has been suggested that the affinity of some neuroleptics to sigma receptors contributes to the therapeutic effect of these drugs (Köhler et al. 1990; Bowen et al.1990). This hypothesis still remains to be confirmed (Jackson et al. 1993), although clinical studies with sigma antagonists failed to demonstrate relevant therapeutic effects in the treatment of schizophrenia (Chouinard and Annable 1984; 
Gewirtz et al. 1994). The fact that certain neuroleptics exhibit a high affinity for dopamine as well as sigma binding sites has increased interest in the characterization of the biology and functional role of sigma binding sites (for a review, see Walker et al. 1990).

It has been postulated that dopaminergic signal transduction may be partially modulated by sigma receptors. This hypothesis has been evaluated using a mouse fibroblast cell line transfected with a eucaryotic expression vector containing the gene of the rat $D_{2}$ receptor (Neve et al. 1989). This cell line also expresses sigma binding sites. Specific sigma ligands do not influence basal, forskolin-stimulated, and forskolinstimulated and quinpirole-inhibited cAMP levels in these cells. These results, although obtained in a particular artificial system, suggest that sigma ligands do not influence dopaminergic $\mathrm{D}_{2}$ signal transduction (Sommermeyer et al. 1993).

Moreover, it has been suggested that sigma binding sites mediate some motor effects induced by certain neuroleptics (Walker et al. 1990; Walker et al. 1988). However, a recent study has failed to confirm these data (Gewirtz et al. 1994). The number and the distribution of sigma binding sites in the CNS are still unknown as well as their possible involvement in the pathogenesis of schizophrenia. Several lines of evidence suggest that sigma receptors may modulate catecholamine release (Berkowitz 1974; Goldstein et al. 1989; Campbell et al. 1987; Arbilla and Langer 1984). It has recently been reported that sigma agonists are able to stimulate rat striatal dopamine synthesis and this effect, which is blocked by the sigma antagonist BMY-14802, is probably mediated by a new class of sigma receptors (Booth and Baldessarini 1991). Further studies are necessary to correctly interpret the effects of sigma ligands on dopaminergic neurons. This is due to the fact that most of the sigma ligands are not selective and may occupy other receptors $\left(\mathrm{PCP}, \mathrm{D}_{2}, 5-\mathrm{HT}_{1 \mathrm{~A}}, 5-\mathrm{HT}_{2 \mathrm{~A}}\right.$, and $\alpha-1$ receptors), which influence dopaminergic neuronal activity (Bunney and DeRiemer 1982; Bunney et al. 1973; Kelland et al. 1990; Zhang et al. 1992a). Moreover only a limited correlation has been established between the activity of sigma ligands on dopaminergic neurons and their affinity for sigma receptors (French and Ceci 1990; Meltzer et al. 1992; Zhang et al. 1992b). Recently, it has been demonstrated that the effects of BMY-14802 on dopamine neuronal firing are indirect, perhaps due in part to occupation of $5-\mathrm{HT}_{1 \mathrm{~A}}$ receptors (Zhang et al. 1993).

In light of the possible presence of an altered glutamatergic neurotransmission in schizophrenia (see the "Excitatory amino acids" section), the recent demonstration of interaction between sigma receptors and glutamatergic neurotransmission is of certain interest. It has been reported, in an in vivo electrophysiologic model, that sigma receptor ligands potentiate the effect of N-methyl-D-aspartate (NMDA) on pyramidal neurons in the CA3 region of the rat dorsal hippocampus. This effect is blocked by the sigma receptor ligands BMY-14802 and haloperidol (Monnet et al. 1992; Bergeron et al. 1993).

Undoubtedly further basic and clinical studies are necessary to understand the involvement of sigma receptors in the pathophysiology of schizophrenia and their possible role in the therapeutic action of antipsychotic drugs. Furthermore, more selective agonists and/or antagonists to sigma receptors will be needed to carry out these studies.

GAMMA-AMINOBUTYRIC ACID. It has been speculated that gamma-aminobutyric acid (GABA) may play a role in the pathophysiology of schizophrenia. In particular the fact that GABA is an inhibitory neurotransmitter led to the idea that in schizophrenics the inhibitory influence of GABAergic neurons on dopaminergic pathways might be decreased, which would result in dopaminergic hyperactivity (Roberts 1972; Van Kammen 1977). In fact, studies of postmortem brain tissue (Cross et al. 1979; Perry et al. 1979; Spokes et al. 1980; Hanada et al. 1987; Benes et al. 1991) and CSF (Lichstein et al. 1978; Hare et al. 1980; Gerner and Hare 1981; Gold et al. 1980; Van Kammen et al. 1989) suggest altered, prevalently reduced, GABAergic neuronal activity in schizophrenia. Discrepancies that exist between the results of the various studies might in part be the result of potential confounding elements, such as treatment with neuroleptic drugs. More recent studies have reported a decreased density of interneurons (Benes et al. 1991) and an increased density of GABA-A receptors in the cingulate cortex in schizophrenia (Benes et al. 1992). It was suggested that a loss of inhibitory, probably GABAergic, interneurons might have given rise to a compensatory upregulation of postsynaptic GABA receptors in the prefrontal and cingulate cortex (Benes et al. 1991). A decreased number of GABA uptake sites, which is considered to reflect a decrease in GABAergic nerve terminals (Czudek and Reynolds 1990), has been measured in the temporal lobe and in particular in the hippocampus of schizophrenic patients (Simpson et al. 1989; Reynolds et al. 1990). The lowest level of GABA uptake sites was found in the left hippocampus, which inversely correlated with the dopamine level in the amygdala (Reynolds et al. 1990). This observation supports the idea that a decrease in the inhibitory action of GABA can increase dopaminergic activity in mesotemporal structures (Reynolds et al. 1990). However, in a study in which the benzodiazepine $\left[{ }^{3} \mathrm{H}\right]$-flunitrazepam was used as a marker of GABAergic receptors, no differences in benzodiazepine binding sites was detected between schizophrenics and controls in the hippocampus (Reynolds and Stroud 1993). In the hippocampus the decreased number of GABA uptake sites seems not to be compensated by an upregulation of 
GABA receptors, whereas in the cingulate cortex, an upregulation in GABAergic receptors was observed. Although these findings are quite interesting, the possibility that they may in part be the result of antipsychotic drug treatment cannot be ruled out.

EXCITATORY AMINO ACIDS. Recent attention has been focused on the possible role of excitatory amino acids, in particular glutamate, in the pathology of schizophrenia. Although the involvement of glutamate in schizophrenia was suggested more than 10 years ago (Kim et al. 1980), interest increased only after a more extensive characterization of the function of the glutamatergic system in the brain. The "glutamate hypothesis" of schizophrenia postulates that a deficiency in glutamatergic neurotransmission is involved in the pathophysiology of this disease (Kim et al. 1980) leading to a disturbed balance between glutamatergic and dopaminergic systems within the striatum and nucleus accumbens (Carlsson and Carlsson 1990). Hence, drugs influencing glutamatergic neurotransmission might be of therapeutic value in the treatment of schizophrenia. The glutamate hypothesis gains support from at least three lines of evidence. First, drugs that block the NMDA subtype of glutamate receptors can precipitate a psychotic-like state in humans. For instance, phencyclidine (PCP), which blocks the ion channel associated with the NMDA receptor complex, elicits a psychotic state in people that includes negative as well as positive symptoms (Domino and Luby 1973; Javitt and Zukin 1991). Similarly, amantadine and memantine, which both are noncompetitive NMDA receptor antagonists (Borman 1989; Kornhuber et al. 1989, 1991), can produce psychotic side effects in Parkinson patients and exacerbate psychotic symptoms in patients with neuroleptic malignant syndrome (Riederer et al. 1991; Kornhuber and Weller 1993). Second, recent studies have shown a reduction in the release of kainate and NMDAinduced glutamate release from synaptosomes of autopsied temporal lobes of schizophrenics compared to controls (Sherman et al. 1991). Third, in postmortem brain tissue of patients with schizophrenia, increased binding of glutamate receptors has been found, which might reflect upregulation due to decreased glutamatergic activity. For instance, increased binding has been reported for $\left[{ }^{3} \mathrm{H}\right]$ kainate, $\left[{ }^{3} \mathrm{H}\right] \mathrm{MK}-801$, and NMDAreceptor associated glycine binding sites in cortical areas of schizophrenic patients (Nishikawa et al. 1983; Deakin et al. 1989; Kornhuber et al. 1989; Ishimaru et al. 1994). Further support for the glutamate hypothesis comes from more recent findings. For instance, a selective loss of glutamatergic neurons has been detected in anterior cingulate cortex, hippocampus, somatomotor cortex, cerebellar cortex, and globus pallidus in small postmortem samples of schizophrenic brains compared to controls without schizophrenia (Squires et al. 1993). Furthermore, using in situ hybridization techniques, a diminished expression of hippocampal non-NMDA glutamate receptor mRNA has been found in the brain of schizophrenic patients compared to controls (Harrison et al. 1991). This last result has been interpreted as an indication of abnormal expression of specific subtypes of glutamatergic receptors (Harrison et al. 1991). Concerning abnormalities in glutamate levels in the brain and CSF of schizophrenic patients, contradictory results have been published. Whereas Kim et al. (1980) reported decreased glutamate CSF levels, others found no changes or even enhanced levels (Gattaz et al. 1982, 1985; Perry 1982; Korpi et al. 1987; Swahn 1990). Alteration in the glutamate levels in the CNS or CSF may reflect changes in glutamatergic metabolism and/or GABAergic transmission within the CNS rather than a change in the neuronal concentration of glutamate. Several lines of evidence indicate a close interrelationship between dopamine and glutamate systems (Carlsson et al. 1993; Carlsson and Carlsson 1990). Experimental findings indicate that dopamine receptors are present on glutamatergic terminals of the corticostriatal pathway, which regulate glutamate release in an inhibitory manner (Schwarcz et al. 1978; Rowlands and Roberts 1980; Mitchell and Dogget 1980). Conversely, glutamate receptors have been suggested to be localized on dopaminergic terminals of the nigrostriatal pathway and to exert a tonic excitatory influence on dopamine release (Roberts and Anderson 1979; Roberts et al. 1982; Grace 1991; Carrozza et al. 1992; Krebs et al. 1991). However, based on the observation that NMDA receptor antagonists failed to decrease basal dopamine release in vivo it was proposed that under physiologic conditions presynaptic NMDA receptors are not involved in directly facilitating tonic dopamine release (Kiss et al. 1994). Thus, PCP, MK-801, and other NMDA receptor antagonists have been reported to stimulate dopamine release and to enhance dopamine turnover (Fessler et al. 1979; Javitt 1987; Gruen et al. 1990; Rao et al. 1990; Imperato et al. 1990). Based on these and other data, it has been proposed that NMDA-mediated neural transmission may be a presynaptic mechanism for the tonic suppression of dopaminergic neurotransmission involving inhibitory interneurons (Javitt et al. 1991; Deutsch et al. 1989). Hence it is conceivable that the hyperactivity of the dopaminergic system present in schizophrenia could result from a relative deficiency of glutamatergic neurotransmission (Deutsch et al. 1989; Carlsson and Carlsson 1990). Finally, it should be pointed out that some experimental data from schizophrenic brains have been interpreted as expression of a localized glutamatergic hyperactivity (Deakin et al. 1989). In summary, several observations suggest the presence of an altered, probably deficient, glutamatergic neurotransmission in schizophrenic brains, which might in part be responsible for increased dopaminergic activity in subcortical and mesotemporal structures. 


\section{MECHANISMS OF ACTION OF CLOZAPINE VERSUS CLASSICAL AND NEWER ANTIPSYCHOTICS}

The clinical efficacy of antipsychotic agents has been generally attributed to their ability to block dopamine $\mathrm{D}_{2}$ receptors in the CNS. This view has been supported by the repeated failure to identify agents effective in alleviating symptoms of schizophrenia that were devoid of dopamine $\mathrm{D}_{2}$ antagonist properties. Moreover the evidence that the in vitro potencies of a wide range of antipsychotics to displace the binding of spiroperidol from striatal membranes closely parallel the clinically effective (antipsychotic) doses has been considered as the strongest argument that the main site of antipsychotic action involves blockade of $\mathrm{D}_{2}$ receptors (Creese et al. 1976).

A considerable body of evidence shows that agents which are only weak antagonists of $\mathrm{D}_{2}$ receptors are as effective antipsychotic drugs as potent antidopaminergic neuroleptics, or even more effective (Kane et al. 1988). Hence the assumption that the complete blockade of $D_{2}$ receptors is essential for diminishing some psychotic symptoms is no longer tenable or, alternatively, that $D_{2}$ blockade is necessary but even weak $D_{2}$ antagonists can ameliorate symptoms if acting in the right place in the brain. Elucidation of the pharmacologic mechanisms underlying the clinical profile of these atypical antipsychotics has stimulated much interest over the past years. In particular the observation that clozapine is an effective antipsychotic agent also in patients not responding to conventional neuroleptics and produces only minimal extrapyramidal side effects has attracted great interest (Kane et al. 1988).

These findings have emphasized the need for a better understanding of the neurochemical mechanisms underlying clozapine's unique clinical profile. The biologic basis of clozapine's pharmacologic spectrum may be related to its interaction with several dopamine receptor subtypes, as well as on noradrenergic and serotoninergic receptors, and its selective influence on mesolimbic dopaminergic system (Coward 1992).

\subsection{Clozapine Profile}

Clozapine has been termed an atypical antipsychotic drug because, in contrast to conventional neuroleptics, it does not produce significant extrapyramidal side effects, does not elevate prolactin levels, and after longterm use does not induce tardive dyskinesia (Baldessarini and Frankenburg 1991; Lindström 1988). The observation that clozapine exerts antipsychotic activity in the absence of extrapyramidal side effects invalidated the hypothesis that both effects are inevitably linked (Caldwell 1978). Furthermore, from a therapeutic point of view, clozapine seems to be superior to classic neu- roleptics as it alleviates both positive and negative symptoms of schizophrenia and is effective in many patients refractory to conventional neuroleptic drugs (Kane et al. 1988). Unfortunately, treatment with clozapine has been found to be associated with a low but significant risk of potentially fatal agranulocytosis (Krupp and Barnes 1992). Therefore, its use has been restricted to patients not responsive to conventional antipsychotics and where regular blood monitoring is possible. Despite this safety problem, the use of clozapine is steadily expanding as the therapeutic benefit is considered to greatly outweigh the risk of developing of agranulocytosis, if this is minimized by regular blood controls. It is understandable that in view of these unique therapeutic properties, numerous studies have been undertaken with the aim of understanding the mechanism of action that distinguishes clozapine from classic neuroleptics. Such knowledge could serve as a basis for the development of efficacious and safer antipsychotic agents.

\subsubsection{Pharmacokinetics and Metabolism of Clozapine.} Clozapine is rapidly and almost completely absorbed from the gastrointestinal tract. Neither the rate nor the extent of absorption are influenced by food (Chrismon et al. 1988). Peak blood levels appear after single and multiple dosing between 0.5 to 4 hours after oral intake. The elimination half-life after single administration is about 12 hours and increases slightly after multiple dosing (Baldessarini and Frankenburg 1991; Choc et al. 1990; Bondesson and Lindström 1988). A relatively large interindividual variation in bioavailability, steadystate plasma concentrations, and clearance has been observed by several investigators (Cheng et al. 1988; Choc et al. 1987). For instance, the oral bioavailability has been found to vary from $22 \%$ to over $90 \%$ and to average at about 50\%-60\% (Baldessarini and Frankenburg 1991). Doses of $300 \mathrm{mg} /$ day produce plasma concentrations between 200 and $600 \mathrm{ng} / \mathrm{ml}$ at steady state (Ereshefsky et al. 1989). Several factors influence the kinetics of clozapine such as age, gender, smoking status, or other drugs. For instance, at a given dose, plasma levels are $20 \%-30 \%$ higher in women than in men and almost two-fold higher in older patients as compared to younger patients (Haring et al. 1989). One study reported lower plasma concentrations in male smokers compared to male nonsmokers (Haring et al. 1989, 1990), whereas another study found no difference (Hasegawa et al. 1993). In patients treated with the antidepressant fluvoxamine, the plasma concentrations of clozapine were increased up to eight-fold probably because fluvoxamine inhibits the metabolism of clozapine (Hiemke et al. 1994). There exists no clear relationship between therapeutic response and plasma clozapine concentration (Ackenheil 1989). However, recent data indicate that antipsychotic activity requires a threshold plasma 
concentration of clozapine within the range 300 to 450 $\mathrm{ng} / \mathrm{ml}$ (Perry et al. 1991; Hasegawa et al. 1993; Potkin et al. 1993). Approximately $95 \%$ of clozapine is bound to plasma proteins. Studies in rats showed that clozapine levels in the brain are up to 24-fold higher than those of serum suggesting that the high plasma protein binding does not impair its availability in the brain (Baldessarini et al. 1993). Clozapine is moderately metabolized by the hepatic P450 microsomal enzyme system mainly to $\mathrm{N}$-oxide and $\mathrm{N}$-demethyl compounds. In addition, small amounts of hydroxy metabolites formed by exchange of the 8-chloro substituent by hydroxyl groups and lactamization of the piperazine ring have been detected. At least $80 \%$ of administered clozapine appears in the urine or feces as metabolites. Clozapine $\mathrm{N}$-oxide and $\mathrm{N}$-demethyl-clozapine are the major metabolites found in human plasma. Centorino et al. (1994) reported that in patients treated with clozapine at an average dose of $294 \mathrm{mg}$, the average plasma levels of unchanged clozapine were $239 \mathrm{ng} / \mathrm{ml}(=0.73$ $\mathrm{mM}$ ) representing $48 \%$ of the total analytes, whereas $\mathrm{N}$-demethyl-clozapine constitutes $41 \%$ and the $\mathrm{N}$-oxide $11 \%$ of the total analytes.

2.1.2. Clozapine Basic Pharmacologic Properties. Ligand binding studies show that clozapine binds to a large number of receptor types. This polyvalent character is an important difference from most classic neuroleptics. As illustrated in Figure 1, clozapine exhibits a relatively high affinity for the newly discovered $D_{4}$ dopamine receptor, for $5-\mathrm{HT}_{2 \mathrm{~A}}, \alpha-1$ and muscarinic $\mathrm{M}-1$ receptors, whereas the affinity to other members of the dopamine $\mathrm{D}_{1}$ and $\mathrm{D}_{2}$ family, to $\alpha-2$ and $5-\mathrm{HT}_{1 \mathrm{~A}}$ receptors is between 10 to 50 times lower. By contrast, haloperidol binds with high affinity to all known subtypes of the $D_{2}$ receptor family, and in addition to $\alpha-1$ and $5-\mathrm{HT}_{2 \mathrm{~A}}$ receptors. In functional tests both clozapine and haloperidol exhibit pure antagonistic properties at the various receptor types (Table 1).

In experimental animals, clozapine, like conventional neuroleptics produces sedation, reduces motor activity and inhibits conditioned avoidance responding. On the other hand, it is almost inactive in several tests considered to recognize neuroleptic drugs (Table 2). For instance, even at high doses it fails to block apomorphine or amphetamine-induced stereotypies and does not produce catalepsy in rats (Eichenberger 1984; Sanger 1985).

Classic neuroleptics are well known to accelerate dopamine turnover, as indicated by increased brain content of the dopamine metabolites, 3,4-dihydroxyphenylacetic acid (DOPAC) and homovanillic acid (HVA). This effect has been suggested to reflect a compensatory increase in the activity of dopamine neurons due to blockade of presynaptic and postsynaptic receptors (Carlsson and Lindqvist 1963). Similar to classic neuroleptics, clozapine also enhances HVA content in the striatum; however, this effect occurs at doses at least 150 times

\section{Clozapine}

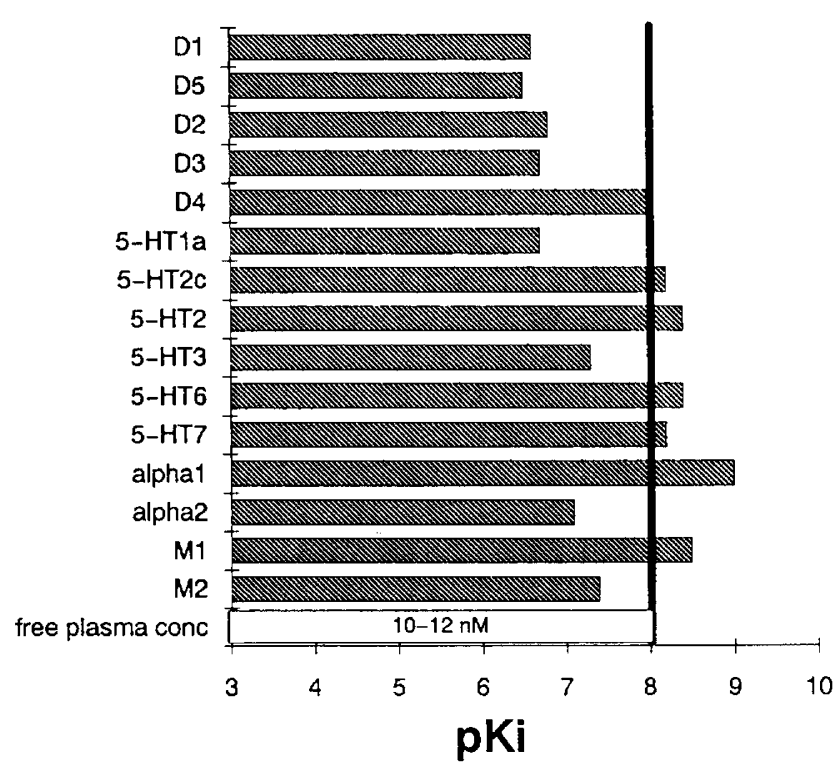

\section{Haloperidol}

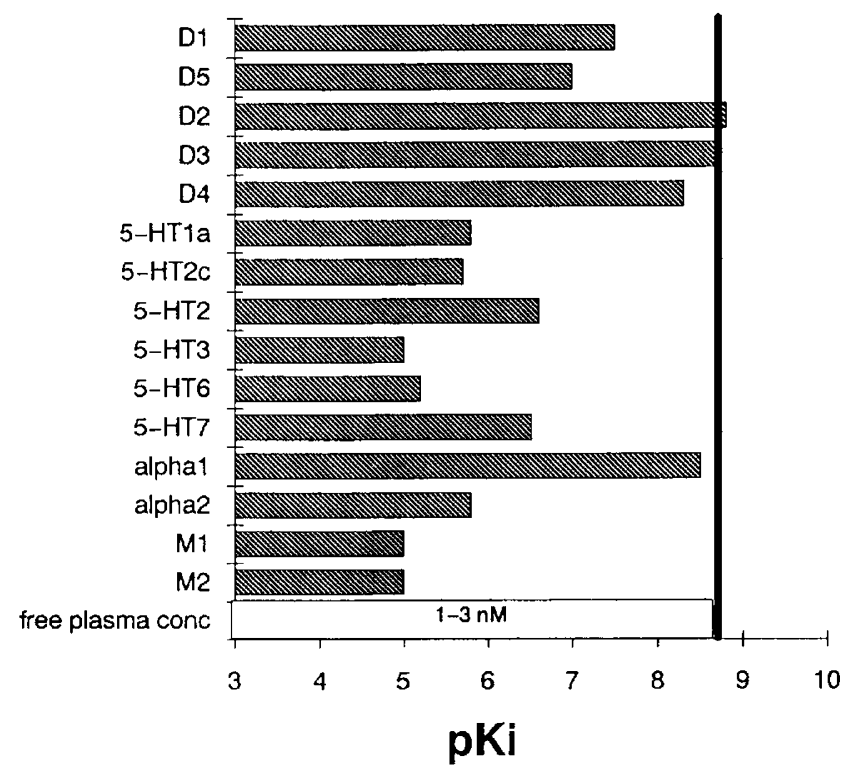

Figure 1. pKi of clozapine and haloperidol toward different receptors: relationship with their free plasma concentrations. The black line represents threshold-free plasma concentrations for therapeutic efficacy (clozapine $=11.7 \mathrm{nM}$; haloperidol = 1 to $3 \mathrm{nM}$ ). An affinity value lower than these concentrations does not have therapeutic efficacy. Binding data from Coward et al. (1992); Van Tol et al. (1991); Bolden et al. (1991); Leysen et al. (1993a); Roth et al. (1994); Sokoloff et al. (1992a); Seabrook et al. (1992); Sunahara et al. (1991). Plasma concentrations from Seeman (1992). 
Table 1. In Vitro Effects of Dopaminergic Agonists and Antagonists in Functional Receptor Tests

\begin{tabular}{llll}
\hline Test (Reference) & Agonist & Clozapine & Haloperidol \\
\hline $\begin{array}{l}\text { Postsynaptic } \mathrm{D}_{1} \text { : adenylate cyclase } \\
\text { from bovine retina }\end{array}$ & Dopamine & $\mathrm{pKi}=6.8$ & $\mathrm{pKi}=7.3$ \\
$\begin{array}{l}\text { Presynaptic } \mathrm{D}_{2}: \text { dopamine release } \\
\text { from rat nucleus accumbens }\end{array}$ & Quinpirole & $\mathrm{pA} 2=7.1$ & $\mathrm{pA} 2=8.6$ \\
$\begin{array}{l}\text { slices }{ }^{b} \\
\begin{array}{l}\text { Postsynaptic } \mathrm{D}_{2} \text { : acetylcholine } \\
\text { release from rat striatal slices }\end{array}\end{array}$ & Apomorphine & $\mathrm{pKi}=7.0$ & $\mathrm{pKi}=9.1$ \\
\hline $\begin{array}{l}a \\
{ }^{a} \text { Markstein (1986). }\end{array}$ & & & \\
${ }^{b}$ Bull and Sheehan (1991).
\end{tabular}

higher than the active dose of haloperidol (Bürki et al. 1974). Furthermore, after acute administration, clozapine $(10 \mathrm{mg} / \mathrm{kg} \mathrm{PO})$ has been reported to enhance and haloperidol ( $3 \mathrm{mg} / \mathrm{kg} \mathrm{PO}$ ) to decrease striatal dopamine content. After repeated administration for 7 days, the effect of clozapine is retained, whereas tolerance develops to the effect of haloperidol (Bürki et al. 1974). Finally, unlike classic neuroleptics, chronic administration of clozapine does not increase the dersity of striatal $\mathrm{D}_{2}$ receptors (Rupniak et al. 1985). All these experimental observations indicate that clozapine is a weak $D_{2}$ receptor antagonist. As expected from its in vitro properties, clozapine also interacts with nondopaminergic systems (Table 3). For instance, it blocks 5-hydroxytryptophan (5-HTP)-induced head twitches in rats, which is compatible with $5-\mathrm{HT}_{2 \mathrm{~A}}$ antagonistic properties. It enhances noradrenaline turnover as shown by increased content of the noradrenaline metabolite (MOPEG.SO $\mathrm{SO}_{4}$ ) indicating antagonistic properties at $\alpha-2$ adrenergic receptors. Finally, clozapine blocks oxotremorine-induced tremor in mice, which reflects antimuscarinic properties (Sayers and Amsler 1977).

Most neurochemical hypotheses that try to explain the atypical character of clozapine have in common that they assume that it is not the specific blockade of one receptor but rather the combined action on several receptor systems that is crucial for its therapeutic actions.

\subsection{Selectivity for Mesolimbic Dopaminergic Neurons}

2.2.1. Dopamine Release and Metabolism. The mesolimbic and mesocortical dopaminergic pathways are thought to be involved in the generation of the symptoms of schizophrenia. The cell bodies are localized in the ventral tegmental area (VTA-A10) of the mesencephalon, and their axons project to numerous structures including olfactory bulb and tubercle, amygdala, anterior olfactory nucleus, septal area, nucleus accumbens, and several cortical areas including cingulate and frontal cortex. Contiguous with the ventral tegmental area is the substantia nigra (A9) whose dopamine neurons densely innervate the neostriatum (caudate-putamen) and also send projections to the globus pallidus. This pathway is called the nigrostriatal tract (Roth et al. 1987).

The effects of neuroleptics on these different dopaminergic systems are not equivalent. Administration of a single dose of neuroleptics enhances dopamine neuron firing in both the nigrostriatal and mesolimbic dopaminergic system. However, when an antipsychotic agent is administered repeatedly (e.g., for 3 weeks or longer), the spontaneous electrical activity of the majority of dopamine neurons ceases (Bunney and Grace 1978). Electrophysiologic and pharmacologic evidence shows that this cessation of activity is not due to an inhibitory effect of the neuroleptic, but instead is a consequence of the maintained excitation of the

Table 2. Behavioral Effects of Clozapine and Haloperidol

\begin{tabular}{llcc}
\hline Test (Species) & \multicolumn{1}{c}{ Dose } & \multicolumn{1}{c}{ Clozapine } & Haloperidol \\
\hline $\begin{array}{l}\text { Catalepsy (rat) } \\
\begin{array}{l}\text { Apomorphine-induced gnawing } \\
\text { (rat) }\end{array}\end{array}$ & ED50 mg/kg SC & Inactive & 0.2 \\
$\begin{array}{l}\text { Apomorphine-induced climbing } \\
\quad \text { (mouse) }\end{array}$ & ED50 $\mathrm{mg} / \mathrm{kg} \mathrm{SC}$ & Inactive & 0.1 \\
$\begin{array}{l}\text { Locomotion (mouse) } \\
\text { Induction of dystonia (monkey) }\end{array}$ & ED50 (30 min) $\mathrm{mg} / \mathrm{kg} \mathrm{PO}$ & 4.3 & 0.03 \\
\hline
\end{tabular}

Data from Stille et al. (1971); Schmutz (1975); Casey (1993). 
Table 3. Clozapine and Haloperidol on In Vivo Effects Not Related to Dopamine

\begin{tabular}{llcc}
\hline Test Model (Species) & \multicolumn{1}{c}{ Measure } & Clozapine & Haloperidol \\
\hline 5-HTP head twitch (mouse) & ED50 mg $/ \mathrm{kg} \mathrm{IP}$ & 0.8 & 0.4 \\
Oxotremorine tremor (mouse) & ED50 mg/kg PO & 14.5 & Inactive \\
MOPEG.SO 4 content in brainstem & $\%$ of controls & $182 \pm 9$ & $143 \pm 6$ \\
\hline $100 \mathrm{mg} / \mathrm{kg}$ PO (rat) & & \\
\hline
\end{tabular}

Data from Sayers and Amsler (1977).

dopamine neuron, which leads to a hyperactivation induced depolarization block of spike generation (Grace and Bunney 1986). Feedback pathways would appear to be involved in the development of depolarization block of both A9 and A10 neurons, because it is completely prevented by prior lesioning of striatonigral pathways and nucleus accumbens (Bunney and Grace 1978). In addition, a large body of evidence indicates that a presynaptic mechanism is responsible for this phenomenon. However, not all antipsychotic agents induce depolarization block of both A9 and A10. For instance clozapine does not affect the nigrostriatal dopamine system, which is believed to mediate extrapyramidal side-effects of neuroleptics. In other words, whereas chronic administration of conventional neuroleptics decreases the furing activity of dopamine neurons in both the A9 (substantia nigra) and A10 (ventral tegmental area) area, chronic administration of clozapine reduces the firing only of A10 dopamine neurons (Chiodo and Bunney 1983). This may account for the low propensity of clozapine to induce extrapyramidal side-effects.

Interaction at nondopaminergic receptors has been suggested to explain the difference between clozapine and conventional neuroleptics with regard to the ability to induce depolarization block of A9 neurons. Although the time course for the induction depolarization block in experimental animals correlates roughly with the onset of the therapeutic effects, recent findings seem to cast doubt on the functional importance of this phenomenon for the pharmacologic effects of antipsychotic agents. It has been speculated that anesthesia might be, in part, responsible for the neurolepticinduced depolarization block (Anden et al. 1988; Ford and Marsden 1986; Kelland et al. 1989; Starle et al. 1990). Thus, the functional significance of depolarization inactivation is questioned because dopamine release from presynaptic terminals is believed not to be strictly correlated with neuron firing (Abercrombie and Zigmond 1990).

With regard to the effect of clozapine on dopamine release, there is considerable controversy as to whether clozapine may affect dopamine release acutely or chronically in various rat brain regions. Clozapine has been reported to produce a dose-dependent blockade of dopamine-induced inhibition of dopamine release from synaptosomes of rat nucleus accumbens, an effect which involves blockade of dopamine autoreceptors (Hetey and Drescher 1986). However, using a slice superfusion system, it has been shown that clozapine does not affect amphetamine-induced dopamine release in the nucleus accumbens, whereas after chronic treatment, it markedly enhanced amphetamine-induced dopamine release into the striatum (Compton and Johnson 1989).

Using in vivo voltammetry, chronic haloperidol has been reported to reduce basal dopamine release in the striatum and nucleus accumbens, whereas chronic clozapine decreased dopamine release only in the nucleus accumbens (Blaha and Lane 1987), supporting the view of a mesolimbic selectivity for clozapine in reducing firing and dopamine release. On the other hand, additional studies, performed with the same technique, failed to support the hypothesis that chronic clozapine inactivates mesolimbic dopamine neurons by producing depolarization block and led to the assumption that an impulse flow-independent mechanism is involved in dopamine release from nerve terminals (Maidment and Marsden 1987).

In order to find possible reasons for these discrepancies and to clarify whether the mesolimbic and mesocortical dopamine systems respond differently to conventional and novel neuroleptics when compared to mesostriatal dopamine neurons or whether depolarization blockade occurs in the mesolimbic-mesocortical system after chronic atypical neuroleptic treatment, in vivo brain microdialysis studies have been carried out.

The results of these investigations have suggested that acute administration of various classes of antipsychotic drugs may differentially increase the extracellular concentration of dopamine in mesotelencephalic systems. Classic neuroleptics, whose action is thought to be mediated mainly through $D_{2}$ receptors, have been found to be more effective in releasing dopamine from the terminals of the nigrostriatal dopamine system, whereas novel agents, including clozapine and fluperlapine, have been reported to have a greater effect on the mesolimbic, and particularly the mesocortical, dopamine system, than that observed in the striatum or nucleus accumbens (Imperato and Angelucci 1989; Moghaddam and Bunney 1990).

As clozapine produces a weaker $\mathrm{D}_{2}$ receptor blockade compared to the typical neuroleptic drugs and as there is no evidence demonstrating a negative feedback 
loop in the mesoprefrontal dopamine system, the action of clozapine on dopamine release, particularly in the prefrontal cortex, appears not to be directly mediated through the blockade of presynaptic and postsynaptic dopamine receptors. Recently, evidence has been provided showing that scopolamine pretreatment inhibits the ability of clozapine to increase extracellular dopamine in the striatum, but not in the nucleus accumbens and prefrontal cortex, whereas scopolamine pretreatment fails to reverse the enhancement of dopamine induced by haloperidol in the striatum (Meltzer et al. 1994). This suggests that clozapine differs from classic neuroleptics in that its ability to increase dopamine release in the striatum acutely depends on muscarinic receptor stimulation.

In addition to previous reports, in vivo microdialysis studies, investigating the effects of repeated antipsychotic administration, indicate that, in contrast to traditional neuroleptics, chronic clozapine produces a selective decrease of basal dopamine efflux in the nucleus accumbens but not in the neostriatum. The dopamine agonist apomorphine, at doses low enough to activate dopamine presynaptic autoreceptors and to hyperpolarize dopamine neurons, reversed clozapineinduced firing inhibition and basal dopamine release in the nucleus accumbens, supporting the notion that clozapine inactivates the mesolimbic system by inducing depolarization blockade (Chen et al. 1991). However, prolonged clozapine treatment did not modify dopamine release in the prefrontal cortex suggesting either a difference between the mesolimbic and mesocortical dopamine pathways in terms of presynaptic transmitter regulation or selectivity of effect of clozapine in the mesencephalic dopamine systems. Acute clozapine challenge in clozapine-treated animals did not produce changes in extracellular dopamine concentration in prefrontal cortex showing that clozapine induces no tolerance in prefrontal cortex. Low doses of apomorphine diminished basal efflux of dopamine in medial prefrontal cortex of rats treated chronically with clozapine, lending support to the assumption that functional dopamine autoreceptors exist within the mesocortical system (Chen et al. 1992).

In contrast to these findings, other studies using in vivo microdialysis found that chronic clozapine did not affect basal dopamine release in the rat nucleus accumbens or striatum (Chai and Meltzer 1992; Invernizzi et al. 1990). In addition, it did not alter the ability of the low dose of apomorphine to decrease dopamine release in either brain areas. The results of these reports are not consistent with the assumption that clozapine differentially affects dopamine release in the mesolimbic versus nigrostriatal system in rats. At the moment, the reasons for the divergent findings by different research groups are not fully understood, because methodologic differences appear to account only in part for the discrepancies. Therefore caution is required be- fore such results can be extrapolated to clinical situations.

2.2.2. Specificity for Dopamine Receptor Subtypes. As mentioned earlier, it is commonly believed that currently used traditional neuroleptics owe their clinical efficacy primarily to a blockade of brain $\mathrm{D}_{2}$ receptors (Davis et al. 1991). Although clozapine binds to dopamine $D_{2}$ receptors, this is not a prominent feature of its binding profile. Available evidence shows that clozapine is also an antagonist at $D_{1}$ receptors in the brain (Meltzer 1991a).

For many years $D_{1}$ receptors have been considered not to be important targets for therapeutic agents (Seeman et al. 1976). However, in recent years new findings led to an enhanced interest in the role of $D_{1}$ receptors. For instance, $D_{1}$ receptors are widely distributed throughout the brain and the $D_{1} / D_{2}$ density ratio is clearly higher in limbic and cortical than in striatal areas (De Keyser et al. 1993). Furthermore, evidence has accumulated showing that $D_{1}$ and $D_{2}$ receptors cooperate in a synergistic manner in the control of motor behavior (Braun and Chase 1986; Robertson and Robertson 1986) and neuronal activity (Weick and Walters 1987). Moreover, it has been suggested that in the neostriatum, but not in other brain areas including the cortex, functional receptors of the $\mathrm{D}_{1}$ and $\mathrm{D}_{2}$ families are co-localized in the majority of efferent neurons (Surmeier et al. 1993). Undoubtedly, the debate concerning the extent to which interacting dopamine receptors are co-localized is still open. Moreover, it has been reported that in postmortem striatum from schizophrenic patients the link between $D_{1}$ and $D_{2}$ receptors is reduced (Seeman et al. 1989). Because $D_{1}$ and $D_{2}$ receptors have opposing actions on adenylate cyclase activity, a linkage between both receptors has been proposed to maintain levels of the second messenger cAMP within close limits despite sharp fluctuations of transmitter concentrations in the synaptic cleft. A defective link between both receptors might result in erratic fluctuations of intracellular cAMP levels and disturbed neuronal functions (Ashby 1990). Hence, a balanced blockade of $D_{1}$ and $D_{2}$ receptors could also in the absence of a functional link produce a buffer effect on intracellular cAMP levels.

Ligand binding studies with membranes of calf and human brains indicate that clozapine binds with almost the same affinity to $D_{1}$ and $D_{2}$ receptors (Coward 1992; Hall et al. 1988). These data are in good agreement with results from functional receptor tests. For instance, clozapine is almost equipotent in reversing $\mathrm{D}_{2}$ agonistmediated inhibition of dopamine release from brain slices and blocking $\mathrm{D}_{1}$ receptor-stimulated adenylate cyclase (Bull and Sheehan 1992; Andersen and Braestrup 1986; Andersen 1988).

In vivo binding experiments in mice also show that 
Table 4. Antidopaminergic In Vivo Effects of Clozapine

\begin{tabular}{|c|c|c|c|}
\hline Animal Test (Reference) & Agonist (mg/kg) & Clozapine (mg/kg) & Effect \\
\hline 6-OHDA-lesioned neonatal rats ${ }^{a}$ & $\begin{array}{l}\text { SKF } 383933.0 \mathrm{IP} \\
\text { LY } 1715550.3 \mathrm{IP}\end{array}$ & $\begin{array}{l}10 \mathrm{IP} \\
25 \mathrm{IP}\end{array}$ & $\begin{array}{l}\operatorname{lm}=p \cdot \text { inhibition } \\
\operatorname{lm}=t \cdot \text { inhibition }\end{array}$ \\
\hline $\begin{array}{l}\text { Neonatal rats with lesions of } \\
\text { DA system }{ }^{a}\end{array}$ & $\begin{array}{l}\text { L-DOPA } 100 \\
+ \text { RO-4-4602 }\end{array}$ & $\begin{aligned} 5 \mathrm{IP} \\
50 \mathrm{IP}\end{aligned}$ & $\begin{array}{l}\text { sn, } \operatorname{lm}=\text { inhibition } \\
\text { sn, } \operatorname{lm}=\text { total inhibition }\end{array}$ \\
\hline Behavior in adult rats ${ }^{b}$ & $\begin{array}{l}\text { Apomorphine } 2.5 \mathrm{SC} \\
\text { Apomorphine } 2.5 \mathrm{SC} \\
\text { SKF } 774340.75 \mathrm{SC} \\
\text { SKF } 774340.75 \mathrm{SC}\end{array}$ & $\begin{array}{l}10 \mathrm{SC} \\
25 \mathrm{SC} \\
2.5 \mathrm{SC} \\
10 \mathrm{SC}\end{array}$ & $\begin{array}{l}\text { st }=\text { no effect } \\
\text { st }=\text { no effect } \\
\text { gr }=\text { inhibition } \\
\text { sn }=\text { inhibition }\end{array}$ \\
\hline Paw test ${ }^{c}$ & $\begin{array}{l}\text { SKF } 383935 \text { IP } \\
\text { LY } 1715551 \text { IP }\end{array}$ & $\begin{array}{l}20 \mathrm{IP} \\
20 \mathrm{IP}\end{array}$ & $\begin{array}{l}\text { hrt }=\text { inhibition } \\
\text { hrt }=\text { no effect }\end{array}$ \\
\hline Behavior in mice ${ }^{d}$ & SKF 383931.87 IP & $\mathrm{ID}_{50}=0.68 \mathrm{IP}$ & gr $=$ inhibition \\
\hline
\end{tabular}

Abbreviations: $1 \mathrm{~m}=$ locomotion, $\mathrm{st}=$ stereotypies, $\mathrm{sn}=$ sniffing, $\mathrm{gr}=$ grooming, $\mathrm{hrt}=$ hind limb retraction time, $\mathrm{RO}-4-4602=$ peripheral decarboxylase inhibitor.

${ }^{a}$ Criswell et al. (1989).

${ }^{b}$ Murray and Waddington (1990).

c Ellenbroek et al. (1991).

${ }^{d}$ Vasse and Protais (1988).

clozapine is almost equipotent in competing with the binding of ligands to $D_{1}$ and $D_{2}$ receptor binding sites (Andersen 1988; Andersen et al. 1986). More importantly, PET studies in patients revealed that conventional doses of clozapine produce a comparable but incomplete occupancy both of $D_{1}$ and $D_{2}$ receptors in the basal ganglia (range $40 \%$ to $50 \%$ ), whereas conventional neuroleptics at therapeutic doses occupy between $70 \%$ to $89 \%$ of $\mathrm{D}_{2}$ receptors with little or no occupancy of $\mathrm{D}_{1}$ receptors (Farde et al. 1992; Farde and Nordström 1992). The possibility that clozapine fails to fully occupy $D_{1}$ and $D_{2}$ receptors because of poor brain penetration can be excluded because clozapine, which also binds to 5-HT2A receptors in vitro, fully displaces radioligands from 5-HT2A sites in rats and in people (Leysen et al. 1992; Nordström et al. 1993). The affinity of clozapine to $D_{1}$ and $D_{2}$ receptors seems to be sufficiently low to allow endogenous dopamine to compete with clozapine at $D_{1}$ and $D_{2}$ receptor sites at least in areas with a high dopamine content such as the striatum (Bacopoulos 1983). This notion is further supported by the observation that repeated administration of clozapine in contrast to conventional neuroleptics fails to increase the density of striatal $\mathrm{D}_{2}$ receptors (Rupniak et al. 1985). Full receptor blockade usually leads to compensatory increases of the respective receptor. The combined but partial blockade of striatal $D_{2}$ and $D_{1}$ receptors by clozapine seems to be a major distinguishing factor from other neuroleptics, which also occupy $D_{1}$ receptors in vivo such as thioridazine and cis-flupenthixol (Farde and Nordström 1992). The observation that $\mathrm{D}_{1}$ antagonism cooperates with weak $\mathrm{D}_{2}$ antagonism to diminish both striatal and mesolimbic behavior has prompted speculations that the synergism known to exist between $D_{1}$ and $D_{2}$ receptors might allow antipsychotic effects to be achieved below the threshold for unwanted motor side effects (O'Dell et al. 1990).

Evidence from behavioral studies supports the view that clozapine is an effective $D_{1}$ receptor antagonist
(Table 4). It antagonized the turning response induced by the selective $D_{1}$ receptor agonist SKF 38393 in unilateral 6-hydroxydopamine (6-OHDA) lesioned rats at smaller doses than were needed to block the effects of the $D_{2}$ receptor agonist quinpirole (LY 171555) (Criswell et al. 1989).

Clozapine also blocks self mutilation resulting from L-DOPA administration to neonatal 6-OHDA-lesioned rats, an effect previously linked to $D_{1}$ dopamine receptor activation, because it is inhibited by the $D_{1}$ receptor antagonist SCH-23390, but not by low doses of the $\mathrm{D}_{2}$ receptor antagonist, haloperidol (Criswell et al. 1989). In the reserpinized rat, clozapine is able to attenuate apomorphine-induced stereotyped behavior in a manner similar to the selective $\mathrm{D}_{1}$ antagonist $\mathrm{SCH}$ 23390 (Chipkin and Latranyi 1987). By contrast, in the intact animal clozapine does not reduce stereotyped behavior induced by the nonselective dopamine agonist, apomorphine (Murray and Waddington 1990). Furthermore, clozapine does not induce catalepsy in rats (Coward 1992; Sayers and Amsler 1977). The failure of clozapine to produce catalepsy is unexpected in the light of a recent study showing that the combination of a selective $D_{1}$ antagonist with a selective $D_{2}$ antagonist results in a potentiated cataleptogenic effect indicating a synergistic effect of $D_{1}$ and $D_{2}$ receptor blockade on the production of catalepsy (Wanibuchi and Usuda 1990). In addition, clozapine readily antagonized intense grooming induced by the selective $\mathrm{D}_{1}$ agonist SKF77434 and in a less consistent manner, reduced hyperactivities induced by the selective $\mathrm{D}_{2}$ agonist LY-163502 (Murray and Waddington 1990). Moreover the effects of clozapine in the paw test for antipsychotic efficacy was blocked by a $D_{1}$ but not a $D_{2}$ agonist (Ellenbroek et al. 1991). Despite its comparable affinities for $D_{1}$ and $\mathrm{D}_{2}$ dopamine receptors in vitro, the behavioral profile of clozapine indicates that it has some preferential, although not selective, effects in vivo to antagonize $D_{1-}$ mediated function. This notion is supported by the 
finding that clozapine attenuates dopamine-induced stimulation of adenylate cyclase to a greater extent than would be expected on the basis of its affinity for $D_{1}$ binding sites (Andersen and Braestrup 1986). For instance, O'Dell et al. (1990) using autoradiographic techniques found that daily administration of clozapine ( 30 $\mathrm{mg} / \mathrm{kg}$ IP) for 21 days enhanced striatal $\mathrm{D}_{1}$ binding, whereas striatal $D_{2}$ binding was not changed. Because an increase in receptor binding usually represents a compensatory event to receptor blockade, the previous result suggests that clozapine in vivo preferentially blocks dopaminergic neurotransmission via functional $D_{1}$ receptors. Furthermore, based on the previous findings it can be speculated that clozapine may produce its antipsychotic like behavioral effects in animals primarily by a blockade of brain $D_{1}$, rather than $D_{2}$, receptors. Although a recent report (Wadenberg et al. 1993), by comparing pharmacologic and behavioral effects of clozapine with those of SCH-23390 and raclopride, provides further support for the notion that $D_{1}$ receptor blockade is relevant for the behavioral effect of clozapine and perhaps for its "peculiar" clinical profile, at present it is difficult to assess the extent to which the atypical properties of clozapine may be ascribed to its action on $D_{1}$ receptor-mediated function. However, the possibility remains that $D_{1}$ receptor antagonism is one of the mechanisms responsible for clozapine behavioral actions. It is of interest that rats treated chronically with clozapine displayed enhanced striatal $D_{1}$ binding without changes in $D_{2}$ receptors, whereas those treated chronically with haloperidol showed enhancement of striatal $D_{2}$ binding with no changes in $D_{1}$ receptor density (Matsubara et al. 1993). The opposite regulation of dopamine receptors induced by chronic treatment with haloperidol and clozapine further suggests that clozapine effects may be in part attributed to its interaction with $D_{1}$ receptors. A number of $D_{1}$ selective antagonists are now available for preclinical and clinical testing. These agents should help in understanding how relevant is $D_{1}$ receptor antagonism in contributing to clozapine actions. It is widely believed that pure $D_{1}$ receptor blockade is not enough to achieve full antipsychotic effects. Therefore, it might be interesting to examine whether the addition of a pure $D_{1}$ antagonist to a $D_{2}$ antagonist could reproduce the pharmacologic profile of clozapine. In other words, the question is whether the combination of a $D_{1}$ with a $D_{2}$ receptor antagonist enhances the antipsychotic action while attenuating the side effects.

However, $D_{1}$ receptor occupancy is not a unique property of clozapine, because in PET studies a significant $D_{1}$ receptor occupancy has been found in subjects medicated with thioridazine and flupenthixol (Farde et al. 1992). Hence, it seems that weak $D_{2}$ receptor blockade is a distinguishing characteristic of clozapine, so that different ratios of $D_{1} / D_{2}$ occupancy might account for the different pharmacologic profiles between clozapine and the potent mixed $D_{1}$ and $D_{2}$ receptor antagonist flupentixol. Thus, the combination of a comparatively low $\mathrm{D}_{2}$ and high $\mathrm{D}_{1}$ receptor occupancy appears to be a more peculiar property of clozapine than binding affinity measured in vitro (Table 5). For instance, loxapine, which in vitro exhibits a binding affinity profile similar to clozapine, resembles a typical antipsychotic because its $D_{2}$ receptor occupancy in vivo is 100 times higher than that of clozapine and similar to that of haloperidol (Stockmeier et al. 1993). This high potency of loxapine at $D_{2}$ dopamine receptors, in vivo compared to its potency in vitro, is probably due to a metabolite of loxapine. Loxapine is converted in vivo into 7-hydroxyloxapine, a compound which is nearly five-fold more potent than loxapine in occupying $D_{2}$ receptors (Coupet and Rauh 1979). Although 7-hydroxyloxapine is not the predominant metabolite of loxapine, its levels in human plasma can approach those of loxapine (Cheung et al. 1991). Thus, metabolic conversion of loxapine may explain the higher occupancy of $\mathrm{D}_{2}$ receptors observed in vivo and consequently the fact that loxapine acts as a typical antipsychotic drug.

Besides the effect on $D_{1}$ and $D_{2}$ receptors, interactions with other dopamine receptors may also contribute to the pharmacologic effect of clozapine. In this regard, particular interest has been attracted by the recently cloned $\mathrm{D}_{3}$ and $\mathrm{D}_{4}$ dopamine receptors (Dall'Olio et al. 1989; Sokoloff et al. 1990). In vitro binding studies have been conducted to evaluate and compare the affinities of clozapine and other antipsychotics toward the recently cloned dopamine receptors (Sokoloff et al. 1990; Sokoloff et al. 1992b). However, in these studies different cell types expressing dopamine receptor subtypes have been used. As it is well known that posttranslational modification of dopamine receptors present in different cell types can modify binding results, this aspect may limit the significance of comparisons of affinity data when these were obtained in different cell types. With this note of caution in mind the suggestion that $\mathrm{D}_{3}$ dopamine receptors could have a key role in the antipsychotic action of novel neuroleptics is primarily

Table 5. Occupancy of Central $\mathrm{D}_{1}, \mathrm{D}_{2}$, and 5-HT2 Receptors in Patients Treated with Neuroleptics

\begin{tabular}{lcc}
\hline & Clozapine & Haloperidol \\
\hline Dosage range (mg/day) & $125-600$ & $4-12$ \\
Free plasma concentration $(\mathrm{nM})$ & $10-12$ & $1-3$ \\
Receptor occupancy & & \\
$\mathrm{D}_{1}$ & $36-52$ & $3-5$ \\
$\mathrm{D}_{2}$ & $38-65$ & $75-85$ \\
Ratio $_{1} / \mathrm{D}_{2}$ & 0.85 & 0.05 \\
$5-\mathrm{HT}_{2}$ & $84-90$ & - \\
\hline
\end{tabular}

Data from Farde et al. (1992); Nordström et al. (1993); Seeman (1992). 
based on the distribution of the mRNA for this receptor subtype found in particularly high density in mesolimbic brain areas (Sokoloff et al. 1992b; Schwartz et al. 1993). Moreover, based on the approximately equal affinity of benzamides for $D_{3}$ and $D_{2}$ receptors, which contrasts with the lower affinity of haloperidol for $\mathrm{D}_{3}$ than $D_{2}$ receptors, it has been proposed that "atypical neuroleptics" interact more selectively with $\mathrm{D}_{3}$ than with $\mathrm{D}_{2}$ receptors compared to "conventional neuroleptics" (Sokoloff et al. 1990). In vitro binding studies, using the same cell type expressing $D_{2}$ or $D_{3}$ dopamine receptors, have shown that clozapine, as well as the great majority of compounds, display comparable affinities for these two receptors. Clorprothixene, levomepromazine, and piflutixol exhibit a 10-fold higher affinity for $D_{3}$ than for $D_{2}$ receptors, whereas the opposite receptor profile is exhibited by butyrophenones and the benzamides halopemide and remoxipride (Sokoloff et al. 1992b).

The discovery that clozapine exhibits, in different cell types expressing $\mathrm{D}_{4}$ or $\mathrm{D}_{2}$ dopamine receptors, a 3 to 10 -fold higher affinity for the recently discovered $D_{4}$ receptor than for the $D_{2}$ receptor led to the proposal that the atypical character of clozapine is related to its antagonistic effect on $\mathrm{D}_{4}$ receptors (Van Tol et al. 1991; Lahti et al. 1993). The $\mathrm{D}_{4}$ receptor hypothesis is complicated by the existence of polymorphic variants of this receptor to which clozapine exhibits different affinities (Van Tol et al. 1992). Although no statistically significant difference in the distribution of $\mathrm{D}_{4}$ receptor variants has been detected so far between schizophrenic patients and normal individuals (Shaikh et al. 1993; Sommer et al. 1993), the existence of an abnormal not yet characterized $\mathrm{D}_{4}$-like receptor variant on which clozapine acts cannot be excluded.

The therapeutically effective plasma concentration for clozapine has been proposed to be $>350 \mathrm{ng} / \mathrm{ml}$ $(>1,000 \mathrm{nM}$ ) (Perry et al. 1991) and for haloperidol 5 to $12 \mathrm{ng} / \mathrm{ml}$ (13 to $32 \mathrm{nM}$ ) (VanPutten et al., 1991). Thus, the therapeutic plasma concentrations of clozapine are up to 70 times higher than those of haloperidol and are in the range necessary to occupy $D_{2}$ and $D_{1}$ receptors. However, as both drugs bind to plasma proteins, only approximately $8.5 \%$ of haloperidol and $2 \%$ of clozapine remain free in the circulating blood. The free concentration of clozapine at therapeutic effective doses is still in the range that would allow occupation of $\mathrm{D}_{4}$ receptors but not (or only a small percentage) of $\mathrm{D}_{2}$ receptors (Seeman 1992; Seeman and Van Tol 1994; Van Tol et al. 1991). By contrast, haloperidol although approximately equipotent to clozapine at the $\mathrm{D}_{4}$ receptor exhibits a two to five times higher affinity in vitro for the other receptors of the $\mathrm{D}_{2}$ family (Van Tol et al. 1991; Sokoloff et al. 1992a). Therefore, it has been proposed that the free plasma concentration of haloperidol at therapeutic doses allows full occupation of $\mathrm{D}_{2}$ and $\mathrm{D}_{3}$, but not of $\mathrm{D}_{4}$ receptors (Seeman 1992). However, it is unsolved whether the free or total circulating concentration is relevant for the drug concentration at critical receptor sites in the brain. For instance, in rats it has been shown that the brain concentration of clozapine is up to 24-fold higher than in the serum (Baldessarini et al. 1993). Furthermore, PET studies in patients have shown that serum concentrations of clozapine close to the therapeutic threshold concentration occupy both $D_{1}$ and $D_{2}$ receptors (Farde et al. 1992). Thus, it remains unclear whether $D_{4}$ receptor blockade is involved in mediating the antipsychotic activity of clozapine. For instance, the observation that remoxipride, a $D_{2}$ receptor antagonist with very little affinity for $D_{4}$ receptors, exerts antipsychotic activity comparable to conventional neuroleptics without producing strong extrapyramidal side-effects (Köhler et al. 1990; Lewander et al. 1990; Kane 1993), suggests that $\mathrm{D}_{4}$ blockade is not a prerequisite for atypical antipsychotic activity. However, remoxipride has been reported not to be effective in chronic or treatment-resistant patients (Vartiainen et al. 1993). Thus, it cannot be excluded that a preferential $\mathrm{D}_{4}$ receptor blocking activity of clozapine is in part responsible for its activity in treatment-resistant patients.

\subsection{Interaction with Serotoninergic Receptor Subtypes}

5-HT2A RECEPTORS. According to a recent hypothesis, the beneficial effect of clozapine on negative symptoms of schizophrenia and its low propensity to induce extrapyramidal side-effects may be associated with its antagonist effects on serotoninergic receptors. This assumption is largely based on the receptor binding characteristics and behavioral pharmacology in experimental animals. There is considerable evidence that antipsychotic drugs that exhibit a high affinity for the 5- $\mathrm{HT}_{2 \mathrm{~A}}$ binding site produce few motor side effects. Furthermore, it has been reported that $5-\mathrm{HT}_{2 \mathrm{~A}}$ antagonists reduce neuroleptic-provoked catalepsy (Maj et al. 1975; Balsara et al. 1979; Hicks 1990) as well as increased antipsychotic-induced dopamine turnover in rats (Saller et al. 1990). Moreover catalepsy generated by neuroleptic agents was attenuated by decreasing brain serotoninergic activity via raphe nuclei lesions or parachlorophenylalanine pretreatment (Kostowski et al. 1972), whereas it was potentiated by activating brain 5-HT mechanisms through the pretreatment with 5-HT reuptake inhibitors or $5-\mathrm{HT}_{2 \mathrm{~A}}$ receptor agonists (Carter and Pycock 1977).

Clozapine and a variety of novel neuroleptics, including fluperlapine and setoperone, exhibit much higher in vitro affinity for $5-\mathrm{HT}_{2 \mathrm{~A}}$ receptors than for classic dopamine receptors (Meltzer et al. 1989). Regardless of the methodologic differences, these in vitro 
findings have been replicated by ex vivo quantitative autoradiography, which has demonstrated that clozapine displaced about $80 \%$ of $\left[{ }^{3} \mathrm{H}\right]$-ketanserin binding, whereas only $10 \%$ of $\left[{ }^{3} \mathrm{H}\right]$-spiperone was displaced (Sokoloff et al. 1992b). Furthermore, it is well known that clozapine also produces an effective $5-\mathrm{HT}_{2 \mathrm{~A}}$ antagonism in vivo. The head twitch response, induced by 5-HTP is generally regarded as a suitable test to access $5-\mathrm{HT}_{2 \mathrm{~A}}$ antagonist activity in vivo. Clozapine showed a potent effect in comparison to haloperidol, which produced only a weak, nonspecific, inhibitory effect, even in doses so high as to provoke full catalepsy (Czyrak et al. 1993). Clozapine as well as risperidone and zotepine antagonized the stimulatory effects of metachlorophenyl-piperazine ( $\mathrm{mCPP}$ ) on the hind limb flexor reflex in spinal rats, providing further evidence for the $5-\mathrm{HT}_{2 \mathrm{~A}}$ antagonistic activity of these agents (Czyrak et al. 1993). Finally, clozapine inhibited the hyperthermic, plasma corticosterone and prolactin responses provoked by MK 212, a 5- $\mathrm{HT}_{2 \mathrm{~A}}$ agonist (Nash et al. 1988; Roth et al. 1992). Studies investigating the degree of receptor occupancy in vivo have demonstrated that, at ED50 for antagonism of these central $5-\mathrm{HT}_{2 \mathrm{~A}}$ receptor-mediated effects, clozapine occupied approximately $40 \%$ of receptors, whereas traditional neuroleptics inhibited the central $5-\mathrm{HT}_{2 \mathrm{~A}}$ receptormediated behavioral effects, at doses that did not produce significant receptor occupancy (Meltzer et al. 1989). Electrophysiologic studies provide further support for the 5-HT $\mathrm{T}_{2 \mathrm{~A}}$ antagonist properties of clozapine. Thus, this agent was able to strongly antagonize the suppressant effect on medioprefrontal cortex cell firing of the relatively selective $5-\mathrm{HT}_{2 \mathrm{~A}}$ agonist $1-(2,5-$ dimethoxy-4-iodophenyl)-2-aminopropane $[( \pm)$-DOI]. In contrast, sulpiride and haloperidol failed to alter DOI's action (Ashby and Wang 1990). Similarly clozapine, but not typical antipsychotics, potently antagonized the ability of 2,5-dimethoxy-4-methylamphetamine, which strongly binds to $5-\mathrm{HT}_{2 \mathrm{~A}}$ receptors, to attenuate the spontaneous activity of locus coeruleus neurons (Rasmussen and Aghajanian 1988). It has been shown that chronic treatment with high doses of clozapine $(20 \mathrm{mg} / \mathrm{kg} /$ day) reduced the number of cortical $5-\mathrm{HT}_{2 \mathrm{~A}}$ receptors (Wilmot and Szczepanik 1989). It is of interest that clozapine and other antipsychotics downregulate $5-\mathrm{HT}_{2 \mathrm{~A}}$ receptors after acute treatment (Matsubara and Meltzer 1989). However, the downregulation does not seem specific to atypical antipsychotics, because it was also observed after treatment with some typical antipsychotic drugs (Matsubara and Meltzer 1989) and other psychopharmacologic agents. In a recent study in psychotic patients, treated with low doses of clozapine, 5-HT $2 \mathrm{~A}$ receptor occupancy in the frontal cortex, as detected by PET studies was found to range between $84 \%$ and $90 \%$, suggesting that $5-\mathrm{HT}_{2} \mathrm{~A}$ recep- tor occupancy might be relevant to the clinical actions of clozapine (Table 5 and Nordström et al. 1993).

$5-\mathrm{HT}_{2 \mathrm{~A}}$ receptors have been detected in several brain regions, and it has been shown that they are involved in a variety of behaviors in rats, some of which seem to reflect schizophrenic symptoms (Bleich et al. 1988). The total number of $5-\mathrm{HT}_{2 \mathrm{~A}}$ binding sites in the frontal cortex of schizophrenics is decreased (Arora and Meltzer 1991), so that it appears difficult to fully understand what the beneficial significance of reducing $5-\mathrm{HT}_{2 \mathrm{~A}}$ binding sites is, if the pathologic process already causes a significant reduction in the number of the $5-\mathrm{HT}_{2 \mathrm{~A}}$ receptor sites. It is possible to speculate that an enhanced serotoninergic activity in schizophrenia may downregulate $5-\mathrm{HT}_{2 \mathrm{~A}}$ receptors, although $5-\mathrm{HT}_{2 \mathrm{~A}}$ transmission still remains increased, so that beneficial effects might arise from $5-\mathrm{HT}_{2 \mathrm{~A}}$ receptor blockade. In the light of these considerations, it would be of great interest to assess the therapeutic potential of $5-\mathrm{HT}_{2 \mathrm{~A}}$ receptor antagonism. Predominant $5-\mathrm{HT}_{2 \mathrm{~A}}$ antagonism is a common property of the majority of novel neuroleptics and putative neuroleptics including amperozide, risperidone, tiosperone, ritanserin, and classic agents such as pipamperone and melperone (Meltzer et al. 1989).

The absolute potencies for binding to $5-\mathrm{HT}_{2 \mathrm{~A}}$ receptor sites vary greatly with the least potent compound, melperone, being 230 times less potent than risperidone, the most potent one. Clinical trials have demonstrated that ritanserin, a $5-\mathrm{HT}_{2 \mathrm{~A}}$ antagonist, exhibits only a weak and questionable antipsychotic effect in schizophrenics, whereas it has been reported that it can reduce akathisia and parkinsonism in patients receiving standard neuroleptic medications (Gerlach 1991). These findings argue against the hypothesis that selective blockade of $5-\mathrm{HT}_{2 \mathrm{~A}}$ receptor subtypes is critically involved in the antipsychotic responses observed with atypical compounds. Conversely, risperidone an agent with both $5-\mathrm{HT}_{2 \mathrm{~A}}$ and $\mathrm{D}_{2}$ receptor antagonist properties, has been reported to attenuate both positive and negative schizophrenic symptoms (Gelders 1989). This would support the hypothesis that combined $5-\mathrm{HT}_{2 \mathrm{~A}}$ and $\mathrm{D}_{2}$ receptor blockade may be relevant to the clinical profile of novel antipsychotics, although there is evidence that concurrent ritanserin administration failed to alter the neuropharmacologic effects due to chronic haloperidol on mesostriatal and mesolimbic dopamine neurons (Saller et al. 1990). Furthermore, risperidone also produces extrapyramidal symptoms at higher doses.

In conclusion the 5- $\mathrm{HT}_{2 \mathrm{~A}}$ antagonist properties of clozapine and other putative atypical antipsychotic drugs are unlikely to account for their clinical efficacy or for their lower propensity to induce neurologic sideeffects (Casey 1993), as chlorpromazine and spiperone, 
two classic neuroleptics also exhibit potent $5-\mathrm{HT}_{2 \mathrm{~A}}$ receptor antagonism (Altar et al. 1988). However, it is more probable that the unique profile of clozapine is the consequence of interaction with various subtypes of receptors.

In light of this hypothesis, there have been in vivo studies in which the capacity of clozapine (and related atypical antipsychotics) and typical antipsychotics to occupy $5-\mathrm{HT}_{2} \mathrm{~A}, \mathrm{D}_{1}$ and $\mathrm{D}_{2}$ receptors have been compared. It has been reported that atypical antipsychotics exhibit in vitro relatively low affinity for $D_{2}$ sites and higher $5-\mathrm{HT}_{2 \mathrm{~A}} / \mathrm{D}_{2}$ affinity ratio compared to typical antipsychotics (Meltzer et al. 1989). Furthermore, in vivo binding data, obtained from rat striatum, cerebral cortex, and olfactory tubercle, confirm that all typical antipsychotics tested strongly occupy $\mathrm{D}_{2}$ receptors, whereas only some of them occupied $5-\mathrm{HT}_{2 \mathrm{~A}}$ receptors and, to a lesser extent, $D_{1}$ receptors (Matsubara et al. 1993; Stockmeier et al. 1993). In contrast, clozapine and other atypical antipsychotics potently occupied $5-\mathrm{HT}_{2 \mathrm{~A}}$ receptors and had limited or no effect on $D_{2}$ and $D_{1}$ receptors (Matsubara et al. 1993; Stockmeier et al. 1993). Moreover, the atypical antipsychotic drugs were more potent in vivo in occupying $\mathrm{D}_{2}$ binding sites in the olfactory tubercle than in striatum (Stockmeier et al. 1993). This last result is in agreement with the observation that atypical antipsychotics interfere less with the striatal dopaminergic system than typical antipsychotics. For typical antipsychotics, but not for atypical ones, a significant correlation was found between in vivo occupancy of $D_{2}$ receptors and the average clinical dose (Stockmeier et al. 1993).

These results clearly indicate that clozapine and other atypical antipsychotics are characterized by high $5-\mathrm{HT}_{2 \mathrm{~A}}$ receptor occupation and less $\mathrm{D}_{2}$ and $\mathrm{D}_{1}$ receptor occupation in vivo (Matsubara et al. 1993; Stockmeier et al. 1993).

5- $\mathrm{HT}_{2 \mathrm{C}}$ RECEPTORS. Available data indicate that clozapine, as well as several other atypical and typical antipsychotic drugs, possesses high affinity for $5-\mathrm{HT}_{2} \mathrm{C}$ receptors (Roth et al. 1992). Based on the affinity for this receptor subtype, Roth and co-workers proposed a classification of antipsychotics into three groups: antipsychotics whose high affinity suggests a functional interaction at therapeutic doses; antipsychotics with a moderate affinity, which may functionally interact when administered at high doses; and antipsychotics with such a low affinity that no significant interaction can be expected at clinical doses. These results do not support the hypothesis that $5-\mathrm{HT}_{2} \mathrm{C}$ affinity is important for the clinical efficacy of clozapine and other atypical antipsychotic drugs. Moreover the high affınity to $5-\mathrm{HT}_{2} \mathrm{C}$ receptors is not a characteristic property shared by all putative atypical antipsychotic compounds (Roth et al. 1992).

$5-\mathrm{HT}_{2 \mathrm{C}}$ receptor binding studies have found that clozapine possesses a subnanomolar affinity, whereas haloperidol shows negligible actions at this receptor (Canton et al. 1990; Roth et al. 1992). In accordance with these results, chronic clozapine treatment downregulates $5-\mathrm{HT}_{2} \mathrm{C}$ receptor sites in rat brain (Hietala et al. 1992). The downregulation of $5-\mathrm{HT}_{2} \mathrm{C}$ receptors differentiates clozapine from traditional neuroleptics (Kuoppamäki et al. 1993a, 1994).

The $5-\mathrm{HT}_{2} \mathrm{C}$ receptor subtype exhibits the highest density in the choroid plexus but is also present in most other parts of the brain. Receptor autoradiographic and in situ hybridization studies revealed the presence of $5-\mathrm{HT}_{2} \mathrm{C}$ receptors in relatively high density in frontal cortex and in limbic areas (Molineaux et al. 1989; Hoffman and Mezey 1989; Mengod et al. 1990), which are believed to be involved in the emotional and cognitive disturbances of schizophrenia.

The main metabolites of clozapine are the $\mathrm{N}$-demethyl- and $\mathrm{N}$-oxide derivatives (Bondesson and Lindström 1988). The $\mathrm{N}$-demethyl derivative and particularly the $\mathrm{N}$-oxide have been reported to be less active than clozapine in several tests for antidopaminergic activity (Schmutz and Eichenberger 1982). However, compared to clozapine the $\mathrm{N}$-demethyl derivative exhibits a higher affinity for $5-\mathrm{HT}_{2} \mathrm{C}$ and a comparable affinity to $5-\mathrm{HT}_{2 \mathrm{~A}}$ receptors (Kuoppamäki et al. 1993b). Because under steady-state conditions the plasma concentration of the $\mathrm{N}$-demethyl derivative is similar to that of clozapine, the question arises whether this metabolite participates in the clinical activity of clozapine. However, it is unclear how well the $\mathrm{N}$-demethyl metabolite penetrates into the brain and more importantly whether $5-\mathrm{HT}_{2 \mathrm{C}}$ and $5-\mathrm{HT}_{2 \mathrm{~A}}$ receptor antagonism is responsible for the atypical properties of clozapine. Although drugs with $5-\mathrm{HT}_{2} \mathrm{C}$ and $5-\mathrm{HT}_{2 \mathrm{~A}}$ antagonistic properties have been reported to substitute for clozapine in a drug discrimination test (Wiley and Potter 1992), other studies came to the conclusion that a high affinity for human $5-\mathrm{HT}_{2 \mathrm{C}}$ receptors does not differentiate atypical from classic antipsychotics (Roth et al. 1993).

The functional significance of $5-\mathrm{HT}_{2 \mathrm{C}}$ antagonism in the unique pharmacologic profile of clozapine is still unclear. However, further studies are required to clarify whether the clozapine-induced alterations in the characteristics of $5-\mathrm{HT}_{2} \mathrm{C}$ receptors may contribute to some of its atypical properties.

5-HT1A RECEPTORS. The recent finding of an increased number of $5-\mathrm{HT}_{1 \mathrm{~A}}$ receptors on pyramidal neurons in prefrontal and temporal cortices of patients with chronic schizophrenia led to an increased interest in this receptor type (Deakin et al. 1989). This observation suggests that interaction at $5-\mathrm{HT}_{1 \mathrm{~A}}$ site may cooperate in regulating cortical glutamatergic transmission, providing the possibility of restoring glutamatergic dysfunction, possibly occurring in schizophrenia (Carlsson and Carlsson 1990). 
In binding studies clozapine showed a $5-\mathrm{HT}_{1 \mathrm{~A}}$ receptor affinity in the micromolar range (Coward et al. 1992), which is not enough, considering the free plasma concentration of clozapine at therapeutic effective doses (Seeman 1992), to occupy $5 \mathrm{HT}_{1 \mathrm{~A}}$ receptors (Figure 1). However, it is unsolved whether the plasma concentration is really relevant for the drug concentration at critical receptor sites in the brain. On the contrary, all other antipsychotics demonstrated much lower preference for the 5- $\mathrm{HT}_{1 \mathrm{~A}}$ site (Mason and Reynold 1992).

Interestingly, compounds structurally related to clozapine, but devoid of its atypical pharmacologic profile, bound to a substantially lesser extent to $5-\mathrm{HT}_{1 \mathrm{~A}}$ receptors (Mason and Reynold 1992).

Globally these data do not exclude the hypothesis that interaction of clozapine at $5 \mathrm{HT}_{1 \mathrm{~A}}$ receptors may be involved in the mechanism underlying its clinical effects, although this hypothesis awaits further substantiation.

5-HT3 RECEPTORS. 5- $\mathrm{HT}_{3}$ receptors have recently attracted much attention, because it has been reported that stimulation of these sites on dopamine terminals may facilitate dopamine release (Blandina et al. 1988). Therefore $5-\mathrm{HT}_{3}$ receptor blockade has been suggested to be of therapeutic potential in schizophrenia. Some preliminary data with $5-\mathrm{HT}_{3}$ antagonists have been reported, but no conclusion can be drawn, as results from large double-blind, controlled trials are awaited (Meltzer 1991b). Clozapine, as well as several other antipsychotic agents, bind to these receptors with relatively low affinity (Watling et al. 1990). It is unlikely that the weak interaction at the $5-\mathrm{HT}_{3}$ site may contribute to clozapine's action.

5-HT6 AND 5-HT7 RECEPTORs. Recently the 5- $\mathrm{HT}_{6}$ (Monsma et al. 1993; Ruat et al. 1993a) and the 5-HT (Bard et al. 1993; Lovenberg et al. 1993a; Plassat et al. 1993; Ruat et al. 1993b; Meyerhof et al., 1993; Shen et al. 1993) receptors have been cloned. $5-\mathrm{HT}_{6}$ receptors seem to be mainly present in the striatum and various antipsychotic and antidepressant drugs appear to bind with high affinity to these receptors (Monsma et al. 1993).

The affinity of several typical and atypical antipsychotic drugs toward these two receptors have been extensively studied using HEK-293 cells stably transfected with $5-\mathrm{HT}_{6}$ receptors and COS-7 cells transiently expressing $5-\mathrm{HT}_{7}$ receptors (Roth et al. 1994). A large number of typical and putative atypical antipsychotic drugs bind with high affinity to the $5-\mathrm{HT}_{6}$ and $5-\mathrm{HT}_{7}$ receptors. Clozapine, as well as other putative atypical antipsychotic drugs, exhibits high affinity for these two receptors. These results indicate that the ability to bind to $5-\mathrm{HT}_{6}$ and/or $5-\mathrm{HT}_{7}$ receptors is not important for obtaining an antipsychotic devoid of extrapyramidal side-effects (Roth et al. 1994). However, the possibility that effects at $5-\mathrm{HT}_{6}$ and $5-\mathrm{HT}_{7}$ receptors may participate in the mechanism of action of those atypical antipsychotic agents possessing high affinity toward these receptors needs to be verified.

\subsection{Interaction with Other Neuronal Systems}

2.4.1. Adrenergic Mechanisms. Although the evidence for a primary noradrenergic abnormality in schizophrenia is not convincing, noradrenaline dysfunctions may influence symptomatology and the course of the disease.

It has been proposed that increased norepinephrine levels are specifically associated with an acute schizophrenic syndrome, whereas chronic stable schizophrenic patients do not show these elevated levels (van Kammen and Antelman 1984).

Therapeutic interventions in psychotic subjects with centrally active antinoradrenergic drugs have led to inconclusive results. By contrast, it has been reported that concurrent chronic administration of prazosin, an $\alpha-1$ antagonist, with a classical neuroleptic, haloperidol, mimicked the clozapine effect in reducing dopamine efflux in nucleus accumbens, as detected by in vivo voltammetry (Lane et al. 1988).

Clozapine shows very high affinity at $\alpha-1$ adrenergic receptor sites, whereas the affinity at $\alpha-2$ and $\beta$ adrenergic receptors is lower. After repeated treatment, clozapine produced a $68 \%$ increase of $\alpha-1$ receptor sites in rat forebrain, and no change in the number of $D_{2}$ receptors (Cohen and Lipinski 1986). Upregulation of $\alpha-1$ but not $D_{2}$ receptors reflects the ratio of potent antiadrenergic over a weak antidopaminergic effect of clozapine. Furthermore, chronic administration of clozapine enhanced the furing rate of noradrenergic neurons in rat locus coeruleus, whereas conventional neuroleptics failed to affect noradrenergic activity at this level (Ramirez and Wang 1986). The blockade of $\alpha-1$ postsynaptic or $\alpha-2$ presynaptic sites may account for this effect as well as for the increased CSF norepinephrine level, occurring after chronic clozapine treatment in schizophrenics (Lieberman et al. 1991). In conclusion, because there is evidence that disturbances in noradrenergic activity may contribute to some aspects of schizophrenia, it cannot be ruled out that the antiadrenergic property of clozapine might be partially involved in its neuropharmacologic activity.

2.4.2. Anticholinergic Mechanisms. Clozapine has a relatively high affinity for muscarinic binding sites (Miller and Hiley 1974). It has been reported to interact with all five cloned human muscarinic receptor subtypes, but has shown higher selectivity for the M1 subtype (Bolden et al. 1992). It has been proposed that this property may, in part, explain its low propensity to induce extrapyramidal side-effects (Miller and Hiley 1976). Clozapine has also been found to reduce the acetylcholine content in the basal ganglia as well as to an- 
tagonize the ability of haloperidol to increase striatal acetylcholine turnover (Racagni et al. 1976). These data provided further support for the view that clozapine's anticholinergic potency is an adequate explanation for its inability to provoke neurologic side-effects. In addition, due to its anticholinergic properties, chronic treatment with clozapine resulted in a marked increase of muscarinic binding sites in mouse brain (Friedman et al. 1983). Moreover, it has been observed that in rodents, the concomitant administration of an anticholinergic with the conventional neuroleptic haloperidol changed haloperidol's functional inhibition of both nigrostriatal and mesolimbic dopamine systems into a selective inhibition of only the mesolimbic dopamine system, thus reproducing the effects observed after clozapine treatment (Chiodo and Bunney 1985; Lane and Blaha 1986).

However, these findings have been recently questioned, because clozapine's functional mesolimbic selectivity has not been replicated by the addition of an anticholinergic compound to haloperidol (Gardner et al. 1993). These recent results are in agreement with previous findings, including animal studies, showing that by combining haloperidol with anticholinergic drugs, a clozapine-like pharmacologic profile was only partly duplicated (Coward et al. 1989). Furthermore, in contrast with anticholinergics, coadministration of clozapine with haloperidol failed to attenuate the enhancement in striatal turnover induced by haloperidol alone (Carvey et al. 1990) and to prevent development of haloperidol-induced behavioral hypersensitivity and proliferation of $\mathrm{D}_{2}$ receptor binding sites (Carvey et al. 1988). Finally, it has been reported that both haloperidol and clozapine, chronically administered for 1 year, did not alter the carbachol-increasing effect on phosphoinositide hydrolysis in rats (Rubinstein et al. 1989), suggesting that effects on cholinergic mechanisms do not completely account for the difference between clozapine and typical antipsychotics. This conclusion also receives support from the clinical observation that combining anticholinergic drugs with conventional neuroleptics, although reducing the incidence of acute extrapyramidal side-effects, does not prevent the development of tardive dyskinesia (Klawans 1973; Gerlach 1977).

In the light of the previous and other results showing that anticholinergics added to conventional neuroleptic medication worsen psychosis and therefore do not produce the superior therapeutic efficacy of clozapine (Singh and Kay 1979; Johnstone et al. 1983), it is unlikely that the intrinsic anticholinergic activity of clozapine participates significantly in the mechanism responsible for its beneficial effects (Richelson 1984; Meltzer and Nash 1991).

2.4.3. GABAergic Mechanisms. Chronic administration of classic neuroleptics decreases GABA turnover within the rat substantia nigra (Mao et al. 1977; Marco et al. 1977) and, probably as a result of this, induces GABAergic supersensitivity in this region (Gale 1980; Frey et al. 1987). In contrast, clozapine enhances nigral GABA turnover when chronically administered. The difference between clozapine's actions and those of standard neuroleptics on nigral GABA sensitivity is believed to be relevant to the appearance of tardive dyskinesia-like phenomena, as demonstrated by investigations in the rat and the monkey (Gunne and Haggstrom 1983; Gunne et al. 1984).

Using in vivo microdialysis, it has been recently reported that clozapine increases GABA release in rat ventral striatum, but not in the globus pallidus, whereas haloperidol induced opposite effects in these areas (Drew et al. 1990). It has been suggested that the interaction of clozapine at the $D_{1}$ receptor may be responsible for the increased GABA efflux in the striatum, because $D_{1}$ receptors are closely associated with striatonigral GABAergic pathways (Coward et al. 1989). Few reports have described the effects of clozapine treatment on GABA receptors. An increase of $\left[{ }^{3} \mathrm{H}\right]-$ flunitrazepam binding sites has been found in membrane preparations from a whole mouse brain, probably related to an increase in GABAergic activity (McPherson et al. 1987), whereas, more recently, a decrease of benzodiazepine receptors in rat frontal cortex and in the olfactory tubercle has been observed (Giardino et al. 1991). At present there is no evidence that the effect of clozapine on GABAergic transmission is relevant for its unique antipsychotic action. On the other hand, drugs interacting with brain GABAergic systems failed to improve schizophrenic symptoms, either alone or in combination with classic neuroleptics (Tamminga and Gerlach 1987).

\subsubsection{Glutamatergic Mechanisms. Contradictory} results exist with regard to a possible interaction of clozapine with glutamatergic neurotransmission. For instance, clozapine has been reported to displace the noncompetitive NMDA receptor antagonist $\left[{ }^{3} \mathrm{H}\right] \mathrm{MK}-$ 801 from binding sites in homogenates of rat striatum with a Ki-value of $0.4 \mathrm{mM}$ and based on electrophysiologic studies to exert antiglutamatergic effects (Lidsky et al. 1993). On the other hand, clozapine and another putative "atypical" neuroleptic, umespirone, have been found to reverse animal behaviors mediated by NMDA receptor antagonists suggesting that, at least at NMDA receptors they act as functional agonists (Schwartz et al. 1987; Schmidt et al. 1991; Hauber 1993). Such a profile would be in line with the glutamate hypothesis of schizophrenia, which postulates that the symptoms of this disease are linked to glutamatergic hypoactivity. Hence, at present it is unclear whether glutamatergic mechanisms play a role in the antipsychotic effect of clozapine. 
2.4.5. Neuropeptides and Endocrine Mechanisms. Evidence has accumulated that neuropeptides localized within midbrain dopamine neurons may be involved in the action of antipsychotic agents. The ability of neuroleptics to facilitate dopamine neuronal activity while blocking dopamine receptors alters the ratio of aminergic to peptidergic transmission within mesotelencephalic systems (Gariano and Groves 1989). The postulated neuroleptic-induced shift from mostly dopaminergic to primarily peptidergic transmission may have several implications, some of which may be relevant to the clinical actions of antipsychotics. Relevant to these clinical actions of antipsychotic is the hyperprolactinemia that represents the most important interaction between the endocrine system and neuroleptic administration. Hyperprolactinemia is a common sideeffect of typical neuroleptic administration but not of treatment with clozapine.

Neurotensin. Preclinical investigations in rats have demonstrated that acute and chronic administration of typical neuroleptics, such as haloperidol, chlorpromazine, and pimozide, produces a significant rise in neurotensin concentrations in specific brain regions, including caudate and nucleus accumbens (Govoni et al. 1980). In contrast, clozapine increased neurotensin levels in nucleus accumbens, but not in caudate (Kilts et al. 1988), whereas other putative novel neuroleptics, such as BMY 14802 and ICI-943, enhanced neurotensin in both areas (Levant and Nemeroff 1990; Levant et al. 1991).

It is noteworthy that phenothiazines devoid of antipsychotic actions failed to affect brain neurotensin concentrations (Govoni et al. 1980). The differential effects of clozapine on neurotensin concentration in rat nucleus accumbens and caudate have been implicated in the low propensity of this compound to induce extrapyramidal side-effects. Animal studies, utilizing in situ hybridization histochemistry, have showed that the effects of haloperidol on neurotensin concentrations in nucleus accumbens and in caudate were preceded by parallel rises in the expression of proneurotensin mRNA (William et al. 1990; Merchant et al. 1991). By contrast, chronic administration of clozapine and remoxipride enhanced neurotensin mRNA expression in nucleus accumbens, but not in caudate nucleus (Merchant and Dorsa, 1993).

By using $[3 \mathrm{H}]$-neurotensin autoradiography, enhanced binding sites were found in the substantia nigra of both humans and rodents chronically treated with haloperidol (Uhl and Kuhar 1984). Recently, evidence has been presented that chronic administration of haloperidol but not clozapine increases the levels of neurotensin mRNA (Bolden-Watson et al. 1993). These preclinical data are consistent with clinical studies showing that antipsychotic drugs are able to increase CSF neurotensin levels in schizophrenic patients (Garver et al. 1991). In fact, this phenomenon may represent the homologue of the well-documented increase in neurotensin occurring in nucleus accumbens and caudate of rodents after antipsychotic treatment. All these findings may have important implications, as neurotensin has been reported to possess neurolepticlike effects in animal investigations, allowing speculation that clozapine's selective effects on mesolimbic neurotensin content may contribute to its unique clinical profile.

Prolactin. The secretion of prolactin from the anterior pituitary is mainly controlled by an inhibitory dopaminergic influence (Ben-Jonathan et al. 1977; Fuxe et al. 1974). Blockade of $D_{2}$ receptor by typical antipsychotics enhances prolactin secretion from anterior pituitary and subsequently leads to increased plasma prolactin concentration. Increased serum prolactin has also been observed after acute clozapine administration (Meltzer et al. 1975; Gudelsky et al. 1987). However, this effect is much weaker and shorter-lasting compared to that observed after typical neuroleptics administration (Meltzer et al. 1975; Gudelsky et al. 1987; Gudelsky et al. 1989). In fact, from a clinical point of view, clozapine does not induce hyperprolactinemia. The minimal effect of clozapine on prolactin has been suggested to be due to a compensatory enhancement of dopamine synthesis in tuberoinfundibular neurons (Gudelsky et al. 1989). However, unlike typical neuroleptics, clozapine does not antagonize the inhibitory effect of dopamine on prolactin release from anterior pituitary cells in culture (Lamberts et al. 1990). The previous findings indicate that the minimal effect of clozapine on prolactin secretion might also be due to interaction with the serotoninergic system at the suprapituitary level (Coward 1992). The inability of clozapine to effectively block the pituitary $D_{2}$ receptors (Meltzer and Gudelsky 1992; Lamberts et al. 1990) is in agreement with the data from biochemical and behavioral studies (see section 2.2.2) showing that this drug is relatively weak in blocking $\mathrm{D}_{2}$ receptors.

OTHER PEPTIDES. Repeated administration of haloperidol reduced preprosomatostatin mRNA in neurons of nucleus accumbens, frontal cortex, and medial striatum, whereas chronic clozapine raised mRNA for preprosomatostatin in the nucleus accumbens, but not in the striatum (Salin et al. 1990). Finally, chronic haloperidol and clozapine differently affected dynorphin peptides and substances $P$ in rat basal ganglia (Nylander and Terenius 1986). As these neuropeptides have been suggested to be involved in motor function, the reported differences on peptide content may be part of the neurochemical mechanisms responsible for the differences in the behavioral effects between novel and conventional neuroleptics.

\section{CONCLUDING REMARKS}

In recent years evidence has accumulated suggesting that schizophrenia might have organic causes. Various 
subtle morphologic and structural abnormalities have been detected in various cortical and limbic areas considered to result in part from neurodevelopmental disturbances. Such abnormalities may be the primary event in schizophrenia and be responsible for disturbed dopaminergic neurotransmission in these regions. If morphologic abnormalities predispose for this illness and are the primary cause of schizophrenia, it is hard to believe that a curative treatment will ever be possible. Thus, treatment will be restricted to symptomatic and preventive therapy. Therefore, effective and welltolerated antipsychotics are necessary. The first antipsychotic agents, now designated classic neuroleptics, have the disadvantages of not improving all symptoms of schizophrenia and of not being effective in all patients and of producing a number of unpleasant and serious and partly irreversible motor side-effects. The discovery of clozapine constitutes a major advance in particular for patients not responding to conventional neuroleptics. There exist many hypotheses for the unique therapeutic effect of clozapine. However, adequate explanations should not only explain why clozapine produces minimal extrapyramidal side-effects but also why it improves both positive and negative symptoms and is active in patients resistant to conventional antipsychotics. Most of the explanations given so far assume that the basis for the antipsychotic activity of clozapine is $\mathrm{D}_{2}$ blockade and that the difference in respect to other antipsychotics is due to the contribution of other receptor interactions. For instance, it has been proposed that $5-\mathrm{HT}_{2 \mathrm{~A}}$ receptor blockade and a high affinity for muscarinic receptors attenuates extrapyramidal side-effects resulting from $\mathrm{D}_{2}$ blockade. Moreover blockade of $5-\mathrm{HT}_{2 \mathrm{~A}}$ receptors could also provide efficacy for negative symptoms. However, the observation that risperidone, a new drug with potent mixed $5-\mathrm{HT}_{2 \mathrm{~A}} / \mathrm{D}_{2}$ antagonist properties, produces catalepsy in rats and at higher doses extrapyramidal symptoms in patients and inconsistently improves negative symptoms does not support this hypothesis (Borison et al. 1992). With the recent discovery of the $D_{4}$ receptor subtype, this receptor has been suggested to play a role in the action of antipsychotic drugs. Even if several classic neuroleptics exhibit high affinity to the $\mathrm{D}_{4}$ receptor, clozapine is more selective for this subtype compared to $D_{2}$ receptors. On the other hand, clozapine differs from all other conventional neuroleptics in two other important aspects. It is a mixed but weak $\mathrm{D}_{1} / \mathrm{D}_{2}$ antagonist and in vivo studies suggest that clozapine produces a combined but only partial blockade of both receptor types. This observation has prompted speculation that the synergism between $D_{1}$ and $D_{2}$ receptors might allow antipsychotic effects to be achieved below the threshold for unwanted motor side-effects. Another interesting property, which distinguishes clozapine from conventional neuroleptics and which is probably related to its $D_{1}$ antagonistic properties, is its effect on dopamine release. Clozapine at lower doses enhances preferentially the extracellular concentration of dopamine in the striatum and prefrontal cortex of awake rats (Imperato and Angelucci 1989). Because dopaminergic hypoactivity in the prefrontal cortex has been suggested to be in part responsible for negative symptoms of schizophrenia, the fact that clozapine indirectly enhances dopaminergic activity in this brain area might explain its efficacy against negative symptoms. However, it cannot be excluded that other nondopaminergic receptor affinities of clozapine also contribute to its unique therapeutic profile. The only way to validate or to disprove one of the various hypotheses mentioned previously is to develop new drugs where the postulated mechanistic profile is specifically realized and to clinically test these compounds.

\section{REFERENCES}

Abercrombie ED, Zigmond MJ (1990): Striatal dopamine release: In vivo evidence for local initiation. Ann NY Acad Sci 604:575-578

Ackenheil M (1989): Clozapine-pharmacokinetic investigations and biochemical effects in man. Psychopharmacology 99:S32-S37

Altar CA, Boyar WC, Wasley A, Gerhardt SG, Liebman JM, Wood WL (1988): Dopamine neurochemical profile of atypical antipsychotic resembles that of $D_{1}$ antagonists. Naunyn-Schmiedeberg's Arch Pharmacol 338:162-168

Anden NE, Grenhoff J, Svensson TH (1988): Does treatment with haloperidol for 3 weeks produce depolarization block in midbrain dopamine neurons of unanesthetized rats? Psychopharmacology 96:558-560

Andersen PH (1988): Comparison of the pharmacological characteristics of ${ }^{3} \mathrm{H}$-raclopride and ${ }^{3} \mathrm{H}-\mathrm{SCH} 23390$ binding to dopamine receptors in vivo in mouse brain. Eur J Pharmacol 146:113-120

Andersen PH, Braestrup C (1986): Evidence for different states of the dopamine $D_{1}$ receptor: Clozapine and fluperlapine may preferentially label an adenylate cyclasecoupled state of the $D_{1}$ receptor. J Neurochem 47:18301831

Andersen PH, Nielsen EB, Gronvald FC, Braestrup C (1986): Some atypical neuroleptics inhibit $\left[{ }^{3} \mathrm{H}\right] \mathrm{SCH} 23390$ binding in vivo. Eur J Pharmacol 120:143-144

Andreasen NC (1988): Brain imaging: Applications in psychiatry. Science 239:1381-1388

Arbilla S, Langer SZ (1984): Differential effects of the stereoisomers of 3-PPP on dopaminergic and cholinergic neurotransmission in superfused slices of the corpus striatum. Naunyn-Schmiedeberg's Arch Pharmacol 327: 6-13

Arnold SE, Hyman BT, Hoesen GWV, Damasio AR (1991a): Some cytoarchitectural abnormalities of the entorhinal cortex in schizophrenia. Arch Gen Psychiatry 48:625-632

Arnold SE, Lee VM, Gur RE, Trojanowski JQ (1991b): Abnormal expression of two microtubule-associated proteins (MAP2 and MAP5) in specific subfields of the hippocam- 
pal formation in schizophrenia. Proc Natl Acad Sci USA $88: 10,850-10,854$

Arora RC, Meltzer HY (1991): Serotonin 2 (5-HT2) receptor binding in the frontal cortex of schizophrenic patients. J Neural Transm 85:19-29

Ashby B (1990): Dopamine and schizophrenia. Nature 348:493

Ashby CR, Wang RY (1990): Effects of antipsychotic drugs on 5 -HT2 receptors in the medial prefrontal cortex: Microiontophoretic studies. Brain Res 506:346-348

Bacopoulos NG (1983): [ $\left.{ }^{3} \mathrm{H}\right]$ dopamine binds to $D_{1}$ and $D_{2}$ receptors in rat striatum. Eur J Pharmacol 87:353-356

Baldessarini RJ, Centorrino F, Flood JG, Volpicelli SA, HustonLyons D, Cohen BM (1993): Tissue concentrations of clozapine and its metabolites in the rat. Neuropsychopharmacology 9:117-124

Baldessarini RJ, Frankenburg FR (1991): Clozapine: A novel antipsychotic agent. New Engl J Med 324:746-754

Balsara JJ, Jadhav JH, Chandorkar AG (1979): Effect of drugs influencing central serotonergic mechanism on haloperidol-induced catalepsy. Psychopharmacology 62:67-69

Bard JA, Zgombick J, Adham N, Vaysse P, Branchek TA, Weinshank RL (1993): Cloning of a novel human serotonin receptor (5-HT7) positively linked to adenylyl cyclase. J Biol Chem 268:23,422-23,426

Beckmann H, Jakob H (1991): Prenatal disturbances of nerve cell migration in the entorhinal region: A common vulnerability factor in functional psychoses? J Neural Transm (Gen Sect) 84:155-164

Ben-Jonathan N, Olivier CH, Weiner HJ, Mical RS, Porter JC (1977): Dopamine in hypophyseal portal plasma of the rat during the oestrus cycle and throughout pregnancy. Endocrinology 100:452-456

Benes F, Sunderland P, Jones BD, LeMay M, Cohen BM, Lipinski JF (1982): Normal ventricles in young schizophrenics. Br J Psychiatry 141:90-93

Benes FM, Davidson J, Bird ED (1986): Quantitative cytoarchitectural studies of the cerebral cortex of schizophrenics. Arch Gen Psychiatry 43:31-35

Benes FM, McSparren J, Bird ED, SanGiovanni JP, Vincent SL (1991): Deficits in small interneurons in prefrontal and cingulate cortices of schizophrenic and schizoaffective patients. Arch Gen Psychiatry 48:996-1001

Benes FM, Vincent SL, Alsterberg G, Bird ED, SanGiovanni JP (1992): Increased GABA-A receptor binding in superficial layers of cingulate cortex in schizophrenics. J Neurosci 12:924-929

Bergeron R, Debonnel G, de Montigny C (1993): Modification of the N-methyl-D-aspartate response by antidepressant sigma receptor ligands. Eur J Pharmacol 240:319-323

Berkowitz BA (1974): Effects of the optical isomers of the narcotic antagonist analgesic pentazocine on brain and heart biogenic amines. Eur J Pharmacol 26:359-365

Berman KF, Randolph C, Gold J, Holt D, Jones DW, Goldberg TE, Carson RE, Herscovitch $\mathrm{P}$, Weinberger DR (1991): Physiological activation of frontal lobe studies with positron emission tomography and oxygen-15 water during working memory tasks. J Cerebr Blood Flow Metab 11 (suppl. 2): $\mathrm{S} 851$

Blaha CD, Lane RF (1987): Chronic treatment with classical and atypical antipsychotic drugs differentially decreases dopamine release in striatum and nucleus accumbens in vivo. Neurosci Lett 78:199-204

Blandina P, Goldfarb J, Green JP (1988): Activation of a 5-HT2 receptor releases dopamine from rat striatal slices. Eur J Pharmacol 155:349-350

Bleich A, Brown S, Kahn R, van Praag H (1988): The role of serotonin in schizophrenia. Schizophr Bull 14:297-315

Bogerts B, Ashtari M, Degreef G, Alvir JMJ, Bilder RM, Lieberman JA (1990a): Reduced temporal limbic structure volumes on magnetic resonance images in first episode schizophrenia. Psychiatry Res 35:1-13

Bogerts B, Falkai P, Haupts M, Greve B, Ernst S, TapernonFranz U, Heinzmann U (1990b): Post mortem volume measurements of limbic system and basal ganglia structures in chronic schizophrenics: Initial results from a new brain collection. Schizophr Res 3:295-301

Bogerts B, Meertz E, Schonfeldt-Bausch R (1985): Basal ganglia and limbic system pathology in schizophrenia. Arch Gen Psychiatry 42:784-791

Bolden C, Cusack B, Richelson E (1991): Clozapine is a potent and selective muscarinic antagonist at the five cloned human muscarinic acetylcholine receptors expressed in CHO-K1 cells. Eur J Pharmacol 192:205-206

Bolden C, Cusack B, Richelson E (1992): Antagonism by antimuscarinic and neuroleptic compounds at the five cloned human muscarinic cholinergic receptors expressed in Chinese hamster ovary cells. J Pharmacol Exp Ther 260:576-580

Bolden-Watson C, Watson MA, Murray KD, Isackson PJ, Richelson E (1993): Haloperidol but not clozapine increases neurotensin receptor mRNA levels in rat substantia nigra. J Neurochem 61:1,141-1,143

Bondesson U, Lindström LH (1988): Determination of clozapine and its $\mathrm{N}$-demethylated metabolite in plasma by use of gas chromatography-mass spectrometry with single ion detection. Psychopharmacology 95:472-475

Booth RG, Baldessarini RJ (1991): (+)-6,7-benzomorphan sigma ligands stimulate dopamine synthesis in rat corpus striatum. Brain Res 557:349-352

Borison RL, Diamond BI, Pathiraja A, Meibach RC (1992): Clinical overview of risperidone. In Meltzer HY (ed), Novel Antipsychotic Drugs. New York, Raven Press, pp 233-239

Bormann J (1989): Memantine is a potent blocker of N-methylD-aspartate (NMDA) receptor channels. Eur J Pharmacol 66:591-592

Bouthenet ML, Souil E, Martres MP, Sokoloff P, Giros B, Schwartz JC (1991): Localization of dopamine $D_{3}$ receptor mRNA in the rat brain using in situ hybridization histochemistry: comparison with dopamine $\mathrm{D}_{2}$ receptor mRNA. Brain Res 564:203-219

Bowen WD, Moses EL, Tolentino PJ, Walkers JM (1990): Metabolites of haloperidol display preferential activity at sigma receptors compared to dopamine $D_{2}$ receptors. Eur J Pharmacol 117:111-118

Braun AR, Chase TN (1986): Obligatory $D_{1} / D_{2}$ receptor interaction in the generation of dopamine agonist related behaviors. Eur J Pharmacol 131:301-306

Brown R, Colter N, Corsellis JAN, Crow TJ, Frith CD, Jagoe $R$, Johnstone EC (1986): Postmortem evidence of structural brain changes in schizophrenia. Differences in brainweight, temporal horn area, and parahippocampal gyrus 
compared with affective disorder. Arch Gen Psychiatry $43: 36-42$

Buerki DR, Ruch W, Asper H, Baggiolini M, Stille G (1974): Effect of single and repeated administration of clozapine on the metabolism of dopamine and noradrenaline in the brain of the rat. Eur J Pharmacol 27:180-190

Bull DR, Sheehan MJ (1991): Presynaptic regulation of electrically evoked dopamine overflow in nucleus accumbens: A pharmacological study using fast cyclic voltammetry in vitro. Naunyn-Schmiedeberg's Arch Pharmacol 343:260-265

Bunney BS, DeRiemer S (1982): Effect of clonidine on dopaminergic neuronal activity in the substantia nigra: Possible indirect mediation by noradrenergic regulation of the serotonergic raphe system. In Friedhoff AJ, Chase TN (eds), Gilles de la Tourette Syndrome. New York, Raven Press, pp 99-104

Bunney BS, Grace AA (1978): Acute and chronic haloperidol treatment: Comparison of effects on nigral dopaminergic cell activity. Life Sci 23:1,715-1,728

Bunney BS, Walters JR, Roth RH, Aghajanian GK (1973): Dopaminergic systems: Effect of antipsychotic drugs and amphetamine on single cell activity. J Pharmacol Exp Ther 195:560-571

Bunzow JR, Van Tol HHM, Grandy DK, Albert P, Salon J, Christie M, Machida CA, Neve KA, Civelli O (1988): Cloning and expression of a rat $\mathrm{D}_{2}$ dopamine receptor CDNA. Nature 336:783-787

Caldwell AE (1978): History of psychopharmacology. In Clark WG, Delgiudice J (eds), Principles of Psychopharmacology. New York, Academic Press, pp 9-40

Campbell BG, Bobker DH, Leslie FM, Mefford IN, Weber E (1987): Both the sigma receptor-specific ligand (+)3-PPP and the PCP receptor-specific ligand TCP act in the mouse vas deferens via augmentation of electrically evoked norepinephrine release. Eur J Pharmacol 138:447-449

Canton H, Verriele L, Colpaert FC (1990): Binding of typical and atypical antipsychotics to 5HT1c and 5HT2 sites: Clozapine potently interacts with 5 HT1c sites. Eur J Pharmacol 191:93-96

Carlsson A (1978): Antipsychotic drugs, neurotransmitters and schizophrenia. Am J Psychiatry 135:164-173

Carlsson A, Lindqvist M (1976): Effect of chlorpromazine or haloperidol on formation of 3-methoxytyramine and normetanephrine in mouse brain. Acta Pharmacol Toxicol 20:140-144

Carlsson A, Svensson A, Carlsson ML (1993): Future strategies in the discovery of new antipsychotic agents: Focus on dopamine-glutamate interactions. In Brunello $\mathrm{N}$, Mendlewicz J, Racagni G (eds), New Generation of Antipsychotic Drugs: Novel Mechanism of Action. Int Acad Biomed Drug Res vol. 4, Basel, Karger, pp 118-129

Carlsson M, Carlsson A (1990): Interactions between glutamatergic and monoaminergic systems within the basal ganglia-implications for schizophrenia and Parkinson's disease. Trends Neurosci 13:272-276

Carrozza DP, Ferraro TN, Golden GT, Reyes PF, Hare TA (1992): In vivo modulation of excitatory amino acid receptors: Microdialysis studies on N-methyl-D-aspartateevoked striatal dopamine release and effects of antagonists. Brain Res 574:42-48

Carter CJ, Pycock CJ (1977): Possible importance of 5-hydroxy- tryptamine in neuroleptic-induced catalepsy in rats. $\mathrm{Br}$ J Pharmacol 60:267-268

Carvey PM, Hitri A, Goetz CG, Tanner CM, Klawans HL (1988): Concurrent treatment with benztropine and haloperidol attenuates the development of behavioral hypersensitivity but not dopamine receptor proliferation. Life Sci 42:2,207-2,215

Carvey PM, Nath ST, Kao LC, Zhang TJ, Lin DH, Singh R, Amdur RL, Klawans HL (1990): Clozapine fails to prevent the development of haloperidol-induced behavioral hypersensitivity in a cotreatment paradigm. Eur J Pharmacol 184:43-53

Casey DE (1993): Serotonergic and dopaminergic aspects of neuroleptic-induced extrapyramidal syndromes in nonhuman primates. Psychopharmacology 112:S55-S59

Centorrino F, Baldessarini RJ, Kando JC, Frankenburg FR, Volpicelli SA, Flood JG (1994): Clozapine and metabolites: Concentrations in serum and clinical findings during treatment of chronically psychotic patients. J Clin Psychopharmacology 14:119-125

Chai B, Meltzer HY (1992): The effect of chronic clozapine on basal dopamine release and apomorphine-induced dopamine release in the striatum and nucleus accumbens as measured by in vivo brain microdialysis. Neurosci Lett 140:47-50

Chen J, Paredes W, Gardner EL (1991): Chronic treatment with clozapine selectively decreases basal dopamine release in nucleus accumbens but not in caudate-putamen as measured by in vivo brain microdialysis: Further evidence for depolarization block. Neurosci Lett 122:127-131

Chen J, Ruan D, Paredes W, Gardner EL (1992): Effects of acute and chronic clozapine on dopaminergic function in medial prefrontal cortex of awake, freely moving rats. Brain Res 571:235-241

Cheng YF, Lundbert T, Bondesson U, Lindström L, Gabrielsson J (1988): Clinical pharmacokinetics of clozapine in chronic schizophrenic patients. Eur J Clin Pharmacol $34: 445-449$

Cheung SW, Tang SW, Remington G (1991): Simultaneous quantification of loxapine, amoxapine, and their 7 - and 8-hydroxy metabolites in plasma by high-performance liquid chromatography. J Chromatogr 564:213-221

Chio CL, Hess GF, Graham RS, Huff RM (1990): A second molecular form of $\mathrm{D}_{2}$ dopamine receptor in rat and bovine caudate nucleus. Nature 343:266-269

Chiodo LA, Bunney BS (1983): Typical and atypical neuroleptics: differential effects of chronic administration on the activity of $\mathrm{A} 9$ and $\mathrm{A} 10$ midbrain dopaminergic neurons. Neuroscience 3:1,607-1,619

Chiodo LA, Bunney BS (1985): Possible mechanisms by which repeated clozapine administration differentially affects the activity of two subpopulations of midbrain dopamine neurons. J Neurosci 5:2,539-2,544

Chipkin RE, Latranyi MB (1987): Similarity of clozapine and SCH-23390 in reserpinized rats suggests a common mechanism of action. Eur J Pharmacol 136:371-375

Choc MG, Hsuan F, Honigfeld G, Robinson WT, Ereshefsky L, Crismon ML, Saklad SR, Hirschowitz J, Wagner R (1990): Single vs multiple dose pharmacokinetics of clozapine in psychiatric patients. Pharm Res 7:347-351

Choc MG, Lehr RG, Hsuan F, Honigfeld G, Smith HT, Bori- 
son R, Volavka J (1987): Multiple-dose pharmacokinetics of clozapine in patients. Pharm Res 4:402-405

Chouinard G, Annable L (1984): An early phase II clinical trial of BW $234 \mathrm{U}$ in the treatment of acute schizophrenia in newly admitted patients. Psychopharmacology 84:282284

Clark D, White FJ (1987): $D_{1}$ dopamine receptor the search for a function. A critical evaluation of the $D_{1} / D_{2}$ dopamine receptor classification and its functional implications. Synapse 1:347-388

Cohen BM, Lipinski JF (1986): In vivo potencies of antipsychotic drugs in blocking alpha 1 noradrenergic and dopamine $D_{2}$ receptors: Implications for drug mechanisms of action. Life Sci 39:2,571-2,580

Colon EJ (1972): Quantitative cytoarchitectonics of the human cerebral cortex in schizophrenic dementia. Acta Neuropathol (Berl) 20:1-10

Compton DR, Johnson KM (1989): Effects of acute and chronic clozapine and haloperidol on in vitro release of acetylcholine and dopamine from striatum and nucleus accumbens. J Pharmacol Exp Therap 248:521-530

Coupet J, Rauh CE (1979): ${ }^{3} \mathrm{H}$-Spiroperidol binding to dopamine receptors in rat striatal membranes: influence of loxapine and its hydroxylated metabolites. Eur J Pharmacol 55:215-218

Coward DM (1992): General pharmacology of clozapine. Br J Psychiatry 160 (suppl. 17):5-11

Coward DM, Imperato A, Urwyler S, White TG (1989): Biochemical and behavioural properties of clozapine. Psychopharmacology 99:S6-S12

Creese I, Burt DR, Snyder SH (1976): Dopamine receptor binding predicts clinical and pharmacological potencies of antischizophrenic drugs. Science 192:481-483

Crismon ML, Ereshefsky L, Saklad SR (1988): A comparison of clozapine absorption in the postprandial versus fasting states. Pharm Res 5:S171

Criswell HE, Mueller RA, Breese GA (1989): Clozapine antagonism of $D_{1}$ and $D_{2}$ dopamine receptor-mediated behaviors. Eur J Pharmacol 159:141-147

Cross A, Crow TJ, Owen F (1979): Gamma-aminobutyric acid in the brain in schizophrenia. Lancet I:560-561

Crow TJ, Baker AJ, Gross MH, Joseph R, Longden A, Owen F, Riley GJ, Glover V, Killpack WS (1979): Monoamine mechanisms in chronic schizophrenia: Postmortem neurochemical findings. Br J Psychiatry 134:249-256

Czudek C, Reynolds GP (1990): $\left({ }^{3} \mathrm{H}\right)$-Nipecotic acid binding to GABA uptake sites in post-mortem human brain. J Neurochem 55:165-168

Czyrak A, Jaros T, Moryl E, Maj J (1993): Pharmacological effects of zotepine and other antipsychotics on the central 5-HT2 receptors. Pharmacopsychiatry 26:53-58

Dal Toso R, Sommer B, Ewert M, Herb A, Pritchett DB, Bach A, Shivers BD, Seeburg PH (1989): The dopamine $D_{2}$ receptor: Two molecular forms generated by alternative splicing. EMBO J 8:4,025-4,034

Dall'Olio R, Roncada P, Vaccheri A, Gandolfi O, Montanaro N (1989): Synergistic blockade of some dopaminemediated behaviors by (-)-sulpiride and SCH23390 in the rat. Psychopharmacology 98:342-346
Daniel DG, Weinberger DR, Jones DW, Zigun JR, Coppola $\mathrm{R}$, Handel S, Bigelow LB, Goldberg TE, Berman KF, Kleinman JE (1991): The effect of amphetamine on regional blood flow during cognitive activation in schizophrenia. J Neurosci 11:1,907-1,917

Davis KL, Kahn RS, Ko G, Davidson M (1991): Dopamine in schizophrenia: A review and reconceptualization. Am J Psychiatry 148:1,474-1,486

De Keyser J, Claeys A, DeBacker JP, Ebinger G, Roels F, Vauquelin $G$ (1988): Autoradiographic localization of the $D_{1}$ and $D_{2}$ dopamine receptors in human brain. Neurosci Lett 91:142-147

Deakin JFW, Slater P, Simpson MCD, Gilchrist AC, Skan WJ, Royston MC, Reynolds GP, Cross AJ (1989): Frontal cortical and left temporal glutamatergic dysfunction in schizophrenia. J Neurochem 52:1,781-1,786

Dearry A, Gingrich JA, Falardeau P, Fremeau RT Jr, Bates MD, Caron MG (1990): Molecular cloning and expression of the gene for a human $\mathrm{D}_{1}$ dopamine receptor. $\mathrm{Na}$ ture 347:72-76

DeLisi LE, Dauphinais ID, Gershon E (1988): Perinatal complications and reduced size of brain limbic structures in familial schizophrenia. Schizophr Bull 14:185-191

Della Vedova F, Fumagalli F, Sacchetti G, Racagni G, Brunello $N$ (1992): Age-related variations in relative abundance of alternative spliced $D_{2}$ receptor mRNAs in brain areas of two rat strains. Mol Brain Res 12:357-359

Deutch SI, Mastropaolo J, Schwartz BL, Rosse RB, Morihisa JM (1989): A glutamatergic hypothesis of schizophrenia. Rationale for pharmacotherapy with glycine. Clin Neuropharmacol 12:1-13

Dohlman HG, Thorner J, Caron MG, Lefkowitz RJ (1991): Model systems for the study of seven-transmembranesegment receptors. Annu Rev Biochem 60:653-688

Domino E, Luby ED (1973): Abnormal mental states induced by phencyclidine as a model of schizophrenia. In Cole JO, Freedman AM, Friedhoff AJ (eds), Psychopathology and psychopharmacology. Johns Hopkins University Press, Baltimore, MD, pp 37-50

Drew KL, O'Connor WT, Kehr J, Ungersted U (1990): Regional specific effects of clozapine and haloperidol on GABA and dopamine release in rat basal ganglia. Eur J Pharmacol 187:385-397

Eichenberger E (1984): Pharmacology of fluperlapine compared with clozapine. Drug Res 34:110-113

Eidne KA, Taylor PL, Zabavnik J, Saunders PTK, Inglis JD (1989): $D_{2}$ receptor, a missing exon. Nature 342:865

Ellenbroek BA, Artz MT, Cools AR (1991): The involvement of dopamine $D_{1}$ and $D_{2}$ receptors in the effects of the classical neuroleptic haloperidol and the atypical neuroleptic clozapine. Eur J Pharmacol 196:103-108

Ereshefsky L, Watanabe MD, Tran-Johnson TK (1989): Clozapine: An atypical antipsychotic agent. Clin Pharmacol 8:691-709

Falkai P, Bogerts B (1986): Cell loss in the hippocampus of schizophrenics. Eur Arch Psychiatry Neurol Sci 236: 154-161

Falkai P, Bogerts B, Rozumek M (1988): Limbic pathology in schizophrenia: The entorhinal region. A morphometric study. Biol Psychiatry 24:515-521 
Farde L, Nordström AL (1992): PET analysis indicates atypical dopamine receptor occupancy in clozapine-treated patients. Br J Psychiatry 160 (suppl. 17):30-33

Farde L, Nordström AL, Wiesel FA, Pauli S, Halldin C, Sedvall G (1992): Positron emission tomography analysis of central $D_{1}$ and $D_{2}$ dopamine receptor occupancy in patients treated with classical neuroleptics and clozapine. Arch Gen Psychiatry 49:538-544

Farde L, Wiesel F-A, Stone-Elander S, Halldin C, Nordström AL, Hall H, Sedvall G (1990): $D_{2}$ dopamine receptors in neuroleptic-naive schizophrenic patients. Arch Gen Psychiatry $47: 213-219$

Farley I, Shannak K, Hornykiewicz D (1980): Brain monoamine changes in chronic paranoid schizophrenia and their possible relation to increased dopamine receptor sensitivity. In Pepeu G, Kuhar M, Enna SJ (eds), Receptor for Neurotransmitters and Peptide Hormones. New York, Raven Press, pp 427-433

Fessler RG, Sturgeon RD, Meltzer HY (1979): Phencyclidineinduced ipsilateral rotation in rats with unilateral 6-hydroxydopamine-induced lesions of the substantia nigra. Life Sci 24:1,281-1,288

Ford APDW, Marsden CA (1986): Influence of anaesthetics on rat striatal dopamine metabolism in vivo. Brain Res 379:162-166

Frangos E, Athanassenas G (1982): Differences in lateral brain ventricular size among various types of chronic schizophrenics: Evidence based on a CT scan. Acta Psychiatr Scand 66:459-463

Fremeau RT, Duncan GE, Fornaretto MG, Dearry AE, Gingrich JA, Breese GR, Caron MG (1991): Localization of $\mathrm{D}_{1}$ dopamine receptor mRNA in brain supports a role in cognitive, affective, and neuroendocrine aspects of dopaminergic neurotransmission. Proc Natl Acad Sci USA 88:3,772-3,776

French ED, Ceci A (1990): Non-competitive N-methyl-Daspartate antagonists are potent activators of ventral tegmental A10 dopamine neurons. Neurosci Lett 119:159162

Frey JM, Ticku MK, Huffman RD (1987): GABAergic supersensitivity within the pars reticulata of the rat substantia nigra following chronic haloperidol administration. Brain Res 425:73-84

Friedman E, Gianutsos G, Kuster J (1983): Chronic fluphenazine and clozapine elicit opposite changes in brain muscarinic receptor binding: Implications for understanding tardive dyskinesia. J Pharmacol Exp Ther 226:7-12

Fuxe K, Hökfelt T, Jonsson G, Lofström A (1974): Aminergic mechanism in neuroendocrine control. In Knowles $F$, Vollrath L (eds), Neurosecretion. The Final Neuroendocrine Pathway. Berlin, Springer-Verlag, pp 269-275

Gale K (1980): Chronic blockade of dopamine receptors by antischizophrenic drugs enhances $\mathrm{GABA}$ binding in substantia nigra. Nature 283:569-570

Gandelman KY, Harmon S, Todd RD, O'Malley KLJ (1991): Analysis of the structure and expression of the human dopamine D4A receptor gene. J Neurochem 56:1,0241,029

Gardner EL, Walker LS, Paredes W (1993): Clozapine's functional mesolimbic selectivity is not duplicated by the addition of anticholinergic action to haloperidol: A brain stimulation study in the rat. Psychopharmacology 110:119-124

Gariano RF, Groves PM (1989): A mechanism for the involvement of colocalized neuropeptides in the action of antipsychotic drugs. Biol Psychiatry 26:303-314

Garver DL, Bissette G, Yao JK, Nemeroff CB (1991): CSF neurotensin concentrations in psychosis: relationship to symptoms and drug response. Am J Psychiatry 148: 485-488

Gattaz WF, Gasser T, Beckmann H (1985): Multidimensional analysis of the concentration of 17 substances in the CSF of schizophrenics and controls. Biol Psychiatry 20:360-366

Gattaz WF, Gattaz D, Beckmann H (1982): Glutamate in schizophrenics and healthy controls. Archives Psichiatrie Nervenkrankheiten 231:221-225

Gauch R, Michaelis W (1991): The metabolism of 8-chloro11-(4-methyl-1-piperazinyl)-5H-dibenzo[b,e]diazepine (clozapine) in mice, dogs, and human subjects. II Farmaco 26:667-681

Gelders YG (1989): Thymosthenic agents, a novel approach in the treatment of schizophrenia. Br J Psychiatry (suppl) 155:33-36

Gerfen CR, Engber TM, Susel Z, Chase TN, Mahan LC, Monsma FJ Jr, Sibley DR (1990): $\mathrm{D}_{1}$ and $\mathrm{D}_{2}$ dopamine receptor-regulated gene expression of striatonigral and striatopallidal neurons. Science 250:1,429-1,432

Gerlach J (1977): The relationship between parkinsonism and tardive dyskinesia. Am J Psychiatry 143:781-784

Gerlach J (1991): New antipsychotics: Classification, efficacy, and adverse effects. Schizophr Bull 17:289-309

Gerner R, Hare T (1981): CSF GABA in normal subjects and patients with depression, schizophrenia, mania and anorexia nervosa. Am J Psychiatry 138:1,098-1,101

Gershanik O, Heikkila RE, Duvoisin RC (1983): Behavioral correlations of dopamine receptor activation. Neurology $33: 1,489-1,492$

Gewirtz GR, Gorman JM, Volavka J, Macaluso J, Gribkoff G, Taylor DP, Borison R (1994): BMY 14802, a sigma receptor ligand for the treatment of schizophrenia. Neuropsychopharmacology 10:37-40

Giardino L, Calzá L, Piazza PV, Amato G (1991): Multiple neurochemical action of clozapine: A quantitative autoradiographic study of DA2, opiate and benzodiazepine receptors in the rat brain after long-term treatment. J Neural Transm (Gen Sect) 83:189-203

Giros B, Martres MP, Sokoloff P, Schwartz JC (1990): Clonage du gene du recepteur dopaminergique $D_{3}$ humain et identification de son chromosome. CR Acad Sci 311: 501-508

Giros B, Sokoloff P, Martres MP, Riou JF, Emorine LJ, Schwartz JC (1989): Alternative splicing directs the expression of two $\mathrm{D}_{2}$ dopamine receptor isoforms. Nature 342:923-926

Gold B, Bowers MB, Roth R, Sweeney P (1980): GABA levels in CSF of patients with psychiatric disorders. Am J Psychiatry 137:362-364

Golden CJ, Graber B, Coffman J, Berg RA, Newlin DB, Bloch S (1981): Structural brain deficits in schizophrenia: Identification by computed tomographic scan density measurements. Arch Gen Psychiatry 38:1,014-1,017 
Goldstein SR, Matsumoto RR, Thompson TL, Patrick RL, Bowen WD, Walker JM (1989): Motor effects of two sigma ligands mediated by nigrostriatal dopamine neurons. Synapse 4:254-258

Govoni S, Hong JS, Yang H-YT, Costa E (1980): Increase of neurotensin content elicited by neuroleptics in nucleus accumbens. J Pharmacol Exp Ther 215:413-417

Grace AA, Bunney BS (1986): Induction of depolarization block in midbrain dopamine neurons by repeated administration of haloperidol: Analysis using in vivo intracellular recording. J Pharmacol Exp Ther 238:1,0921,100

Grace AA (1991): Phasic versus tonic dopamine release and the modulation of dopamine system responsivity: A hypothesis for the etiology of schizophrenia. Neuroscience 41:1-24

Grandy DK, Marchionni MA, Makam H, Stofko RE, Alfano M, Frothingham L, Fisher JB, Burke-Howie KJ, Bunzow JR, Server AC, Civelli O (1989): Cloning of the cDNA and gene for a human $\mathrm{D}_{2}$ dopamine receptor. Proc Natl Acad Sci USA 86:9,762-9,766

Grandy DK, Zhang Y, Bouvier C, Zhou QY, Johnson RA, Allen L, Buck K, Bunzow JR, Salon J, Civelli O (1991): Multiple human $D_{5}$ dopamine receptor genes: A functional receptor and two pseudogenes. Proc Natl Acad Sci USA $88: 9,175-9,179$

Griffiths EC, McDermott JR, Smith AI (1984): A comparative study of neurotensin inactivation by brain peptidases from different vertebrate species. Comp Biochem Physiol 77C:363-366

Gruen RJ, Roth RH, Bunney BS, Moghadam B (1990): Increase in striatal dopamine release following local perfusion of the NMDA receptor antagonist 2-amino-5-phosphonopentanoic acid. Soc Neurosci Abstr 16:679

Gudelsky GA, Koenig JI, Simonovic M, Koyama T, Ohmori T, Meltzer HY (1987): Differential-effects of haloperidol, clozapine, and fluperlapine on tuberoinfundibular dopamine neurons and prolactin secretion in the rat. J Neural Transm 68:227-240

Gudelsky GA, Nash JF, Berry SA, Meltzer HY (1989): Basic biology of clozapine: Electrophysiological and neuroendocrinological studies. Psychopharmacology 99:S13-S17

Gunne L-M, Haggstrom J-E, Sjoquist B (1984): Association with persistent neuroleptic-induced dyskinesia of regional changes in brain GABA synthesis. Nature 309: 347-349

Gunne LM, Haggstrom J-E (1983): Reduction of nigral glutamic acid decarboxylase in rats with neuroleptic-induced dyskinesia. Psychopharmacology 81:191-194

Hall H, Farde L, Sedvall G (1988): Human dopamine receptor subtypes: In vitro binding analysis using ${ }^{3} \mathrm{H}-\mathrm{SCH} 23390$ and ${ }^{3}$ H-raclopride. J Neural Transm 73:7-21

Hanada S, Mita T, Nishinok N, Tanaka C (1987): ${ }^{3} \mathrm{H}$-muscimol binding sites increased in autopsied brains of chronic schizophrenics. Life Sci 40:259-266

Hare T, Word J, Bala-Manyam N, Ballenger J, Post R, Gerner $R$ (1980): Selection of control populations for clinical cerebrospinal fluid GABA investigations based on comparison with normal volunteers. Brain Res Bull 5:721-724

Haring C, Meise U, Humpel C, Saria A, Fleischhacker WW, Hinterhüber H (1989): Dose-related plasma levels of clozapine influence of smoking behavior, sex and age. Psychopharmacology 99 (suppl.): S38-S40

Haring C, Fleischhacker WW, Schett P, Humpel C, Barnas C, Saria A (1990): Influence of patient-related variables on clozapine plasma levels. Am J Psychiatry 147:1,4711,475

Harrison PJ, McLaughlin D, Kerwin RW (1991): Decreased hippocampal expression of a glutamate receptor gene in schizophrenia. Lancet 337:450-452

Hashimoto T, Kitamura N, Kajimoto Y, Shirai Y, Shirakawa O, Mita T, Nishino N, Tanaka C (1993): Differential changes in serotonin 5-HT1a and 5-HT2 receptor binding in patients with chronic schizophrenia. Psychopharmacology 112:S35-S39

Hashimoto T, Nishino N, Nakai H, Tanaka C (1991): Increase in 5-HT1A receptors in prefrontal and temporal cortices of brains from patients with schizophrenia. Life Sci 48:355-363

Heckers S, Heinsen H, Geiger B, Beckmann H (1991): Hippocampal neuron number in schizophrenia. Arch Gen Psychiatry 48:1,002-1,008

Heckers S, Heinsen H, Heinsen Y, Beckmann H (1990): Limbic structures and lateral ventricle in schizophrenia. Arch Gen Psychiatry 47:1,016-1,022

Heritch AJ (1990): Evidence for reduced and dysregulated turnover of dopamine in schizophrenia. Schizophr Bull $16: 605-615$

Hetey L, Drescher K (1986): Influence of antipsychotic are presynaptic receptors modulating the release of dopamine in synaptosomes of the nucleus accumbens of rats. Neuropharmacology 25:1,103-1,109

Hicks PB (1990): The effect of serotonergic agents on haloperidol-induced catalepsy. Life Sci 47:1,609-1,615

Hiemke C, Weigmann H, Härtter S, Dahmen N, Wetzel H, Müller H (1994): Elevated levels of clozapine in serum after addition of fluvoxamine. J Clin Psychopharmacol 14:279-281

Hietala J, Koulu M, Kuoppamäki M, Lappalainen J, Syvälahti E (1992): Chronic clozapine treatment downregulates serotonin 5-HT1c receptors in rat brain. Prog Neuropsychopharmacol \& Biol Psychiatry 16:727-732

Hoffman BJ, Mezey E (1989): Distribution of serotonin 5-HT1c receptor mRNA in adult rat brain. FEBS Lett 247:453-462

Imperato A, Angelucci L (1989): The effects of clozapine and fluperlapine on the in vivo release and metabolism of dopamine in the striatum and the prefrontal cortex of freely moving rats. Psychopharmacol Bull 25:383-389

Imperato A, Scrocco MG, Bacchi S, Angelucci L (1990): NMDA receptors and in vivo dopamine release in the nucleus accumbens and caudatus. Eur J Pharmacol 187:555-556

Invernizzi R, Morali F, Pozzi L, Samanin R (1990): Effects of acute and chronic clozapine on dopamine release and metabolism in the striatum of conscious rats. Br J Pharmacol 100:774-778

Iversen LL (1993): The $D_{4}$ and schizophrenia. Nature 365:393

Jackson DM, Mohell N, Bengtsson A, Malmberg A (1993): What are atypical neuroleptics and how do they work? In Brunello N, Mendlewicz J, Racagni G (eds), New generation of antipsychotic drugs: Novel mechanisms 
of action. Int Acad Biomed Drug Res, vol 4, Basel, Karger, pp 27-38

Jakob H, Beckmann H (1986): Prenatal developmental disturbances in the limbic allocortex in schizophrenics. J Neural Transm 65:303-326

Jann MW, Grimsley SR, Gray EC, Chang WH (1993): Pharmacokinetics and pharmacodynamics of clozapine. Clin Pharmacokinetics 24:161-176

Javitt DC (1987): Negative symptomatology and the PCP (phencyclidine) model of schizophrenia. Hill-side. J Clin Psychiatry 9:12-35

Javitt DC, Zukin SR (1991): Recent advances in the phencyclidine model of schizophrenia. Am J Psychiatry 148: 1,301-1,308

Jeste DV, Lohr JB (1989): Hippocampal pathological findings in schizophrenia: a morphometric study. Arch Gen Psychiatry $46: 1,019-1,024$

Johnstone EC, Crow TJ, Ferrier IN, Firth CD, Owens DGC, Bourne RC, Gamble SJ (1983): Adverse effects of anticholinergic medication on positive schizophrenic symptoms. Psychol Med 13:513-527

Johnstone EC, Crow TJ, Frith CD, Husband J, Kreel L (1976): Cerebral ventricular size and cognitive impairment in chronic schizophrenia. Lancet 2:924-926

Jones RSG (1993): Entorhinal-hippocampal connections: A speculative view of their function. Trends Neurosci 16:58-64

Joseph MH, Baker HF, Crow TJ, Riley GJ, Rigsby D (1979): Brain tryptophan metabolism in schizophrenia: A postmortem study of metabolites on the serotonin and kynurenine pathways in schizophrenia and control subjects. Psychopharmacology 62:279-285

Joyce JN (1993): The dopamine hypothesis of schizophrenia: Limbic interactions with serotonin and norepinephrine. Psychopharmacology 112:S16-S34

Joyce JN, Shane A, Lexow N, Winokur A, Casanova MF, Kleinman JE (1993): Serotonin uptake sites and serotonin receptors are altered in the limbic system of schizophrenics. Neuropsychopharmacology 8:315-336

Kahn RS, Davidson M (1993): Serotonin, dopamine and their interactions in schizophrenia. Psychopharmacology 112: S1-S4

Kane J, Honigfeld G, Singer J, Meltzer HY (1988): Clozapine for the treatment-resistant schizophrenic. Arch Gen Psychiatry 45:789-796

Kane J, Honigfeld G, Singer J, Meltzer H (1989): Clozapine for treatment-resistant schizophrenic: Results of a US multicenter trial. Psychopharmacology 99:S60-S63

Kane JM (1993): Newer antipsychotic drugs. A review of their pharmacology and therapeutic potential. Drugs 46: 585-593

Kanterman RY, Mahan LC, Briley EM, Monsma FJ Jr, Sibley DR, Axelrod J, Felder CC (1991): Transfected $D_{2}$ dopamine receptors mediate the potentiation of arachidonic acid release in Chinese hamster ovary cells. Mol Pharmacol 39:364-369

Kelland MD, Freeman AS, Chiodo LA (1989): Chloral hydrate anesthesia alters the responsiveness of identified midbrain dopamine agonist administration. Synapse 3:30-37
Kelland MD, Freeman AS, Chiodo LA (1990): Serotonergic afferent regulation of the basic physiology and pharmacological responsiveness of nigrostriatal dopaminergic neurons. J Pharmacol Exp Ther 253:803-811

Kelsoe JR, Cadet JL, Pickar D, Weinberger DR (1988): Quantitative neuroanatomy in schizophrenia: a controlled magnetic resonance imaging study. Arch Gen Psychiatry 45:533-541

Kerwin RW, Patel S, Meldrum BS, Czudek C, Reynolds GP (1988): Asymmetrical loss of glutamate receptor subtype in left hippocampus in schizophrenia. Lancet 1:583-584

Kilts CD, Anderson CM, Bissette G, Ely TD, Nemeroff CB (1988): Differential effects of antipsychotic drugs on the neurotensin content of discrete brain nuclei. Biochem Pharmacol 37:1,547-1,554

Kim JS, Kornhuber $\mathrm{HH}$, Schmid-Burgk W, Holzmuller B (1980): Low cerebrospinal fluid glutamate in schizophrenic patients and a new hypothesis on schizophrenia. Neurosci Lett 20:379-382

Kitabgi P (1989): Neurotensin modulates dopamine neurotransmission at several levels along brain dopaminergic pathways. Neurochem Int 14:111-119

Klawans HL (1973): The pharmacology of tardive dyskinesias. Am J Psychiatry 130:82-86

Köhler C, Hall H, Magnusson O, Lewander T, Gustafsson K (1990): Biochemical pharmacology of the atypical neuroleptic remoxipride. Acta Psychiatr Scand 82 (suppl. 358): $27-36$

Kornhuber J, Bormann J, Hubers M, Rusche K, Riederer P (1991): Effects of the 1-amino-adamantanes at the MK801-binding site of NMDA-receptor-gated ion channela human postmortem brain study. Eur J Pharmacol (Mol Pharmacol Sect) 206:297-300

Kornhuber J, Bormann J, Retz W, Hubers M, Riederer P (1989): Memantine displaces $(3 \mathrm{H}) \mathrm{MK}-801$ at therapeutic concentrations in post-mortem human frontal cortex. Eur J Pharmacol 166:589-590

Kornhuber J, Weller M (1993): Amantadine and the glutamate hypothesis of schizophrenia. Experiences in the treatment of neuroleptic malignant syndrome. J Neural Transm 92:57-65

Korpi ER, Kaufman CA, Marneal K-M, Weinberger DR (1987): Cerebrospinal fluid amino acid concentrations in chronic schizophrenia. Psychiatry Res 20:337-345

Korpi ER, Kleinman JE, Goodman SI, Phillips I, DeLisi LE, Linnoila M, Wyatt RJ (1986): Serotonin and 5-hydroxyindolacetic acid in the brain of suicide victims: Comparison in chronic schizophrenic patients with suicide as the cause of death. Arch Gen Psychiatry 43:594-600

Kostowski W, Gumulka W, Czlonkowski A (1972): Reduced cataleptogenic effects of some neuroleptics in rats with lesioned midbrain raphe and treated with p-chlorophenylalanine. Brain Res 48:443-446

Kovelman JA, Scheibel AB (1984): A neurohistological correlate of schizophrenia. Biol Psychiatry 19:1,601-1,621

Krebs MO, Desce JM, Kemel ML, Gauchy C, Godeheu G, Cheramy A, Glowinski J (1991): Glutamatergic control of dopamine release in the rat striatum: Evidence for presynaptic N-methyl-D-aspartate receptors on dopaminergic nerve terminals. J Neurochem 56:81-85 
Krupp P, Barnes P (1992): Clozapine-associated agranulocytosis: Risk and aetiology. Br J Psychiatr 160 (suppl. 17):38-40

Kuoppamäki M, Pälvimäki EP, Syvälahti E, Hietala J (1994): 5-HT1C receptor-mediated phosphoinositide hydrolysis in the rat choroid plexus after chronic treatment with clozapine. Eur J Pharmacol 255:91-97

Kuoppamäki M, Seppala T, Syvälahti E, Hietala J (1993a): Chronic clozapine treatment decreases 5-hydroxytryptamine 1c receptor density in the rat choroid plexus: Comparison with haloperidol. J Pharmacol Exp Ther 264: $1,262-1,267$

Kuoppamäki M, Syvälahti E, Hietala J (1993b): Clozapine and $\mathrm{N}$-desmethylclozapine are potent 5 -HT1C receptor antagonists. Eur J Pharmacol (Mol Pharmacol Sect) 245: 179-182

Lahti RA, Evans DL, Stratman NC, Figur LM (1993): Dopamine $D_{4}$ versus $D_{2}$ receptor selectivity of dopamine receptor antagonists: Possible therapeutic implications. Eur J Pharmacol 236:483-486

Lamberts SWJ, van Koetsveld PM, Hofland LJ (1990): The effect of clozapine on prolactin secretion at the level of the lactotroph. Life Sci 46:1,013-1,019

Lane RF, Blaha CD (1986): Electrochemistry in vivo: Application to CNS pharmacology. Ann NY Acad Sci 473:50-69

Lane RF, Blaha CD, Rivet JM (1988): Selective inhibition of mesolimbic dopamine release following chronic administration of clozapine: Involvement of alpha 1-noradrenergic receptor demonstrated by in vivo voltammetry. Brain Res 460:398-401

Le Moine C, Normand E, Bloch B (1991): Phenotypical characterization of the rat striatal neurons expressing the $D_{1}$ dopamine receptor gene. Proc Natl Acad Sci USA 88: 4,205-4,209

Le Moine C, Tison F, Bloch B (1990): D2 dopamine receptor gene-expression by cholinergic neurons in the rat striatum. Neurosci Lett 117:248-252

Lee T, Seeman P, Tourtellotte WW, Farley IJ, Hornykiewicz $\mathrm{O}$ (1978): Binding of ${ }^{3} \mathrm{H}$-neuroleptics and ${ }^{3} \mathrm{H}$-apomorphine in schizophrenic brains. Nature 274:897-900

Leeman SE, Carraway RE (1982): Neurotensin: Discovery, isolation, characterization, synthesis, and possible physiological roles. Ann NY Acad Sci USA 400:1-16

Levant B, Bissette G, Davis D, Heffner TG, Nemeroff CB (1991): Effects of Cl-943, a potential antipsychotic drug, and haloperidol on regional brain neurotensin concentrations. Synapse 9:225-230

Levant B, Nemeroff CB (1988): The psychobiology of neurotensin. Curr Top Neuroendocrinol 8:231-262

Levant B, Nemeroff CB (1990): Sigma receptor "antagonist" BMY 14802 increases neurotensin concentrations in the rat nucleus accumbens and caudate. J Pharmacol Exp Ther 254:330-335

Levin S, Yurgelin-Todd D, Craft S (1989): Contributions of clinical neuropsychology to the study of schizophrenia. J Abnorm Psychol 98:341-356

Lewander T, Westerbergh SE, Morrison D (1990): Clinical profile of remoxipride: A combined analysis of a comparative double-blind multicenter trial programme. Acta Psychiatr Scand 82 (suppl. 358):92-98
Leysen JE, Gommeren W, Mertens J, Luyten WHML, Pauwels PJ, Ewert M, Seeburg P (1993a): Comparison of in vitro binding properties of a series of dopamine antagonists and agonists for cloned human $D_{2} S$ and $D_{2} l$ receptors and for $D_{2}$ receptors in rat striata and mesolimbic tissues using [125]-2'-iodospiperone. Psychopharmacology 110: 27-36

Leysen JE, Janssen P, Gommeren W, Wynants J, Pauwels PJ, Janssen PAJ (1992): In vitro and in vivo binding and effects on monoamine turnover in rat brain regions of the novel antipsychotics risperidone and ocaperidone. Mol Pharmacol 41:494-508

Leysen JE, Janssen PMF, Schotte A, Luyten WHML, Megens AAHP (1993b): Interaction of antipsychotic drugs with neurotransmitter receptor sites in vitro and in vivo in relation to pharmacological and clinical effects: role of $5 \mathrm{HT} 2$ receptors. Psychopharmacology 112:S40-S54

Lichstein D, Dobkin J, Ebstein R, Biederman J, Rimon R, Belmaker $R$ (1978): Gammaaminobutyric acid (GABA) in the CSF of schizophrenic patients before and after neuroleptic treatment. Br J Psychiatry 132:145-148

Lichter JB, Barr CL, Kennedy JL, Van Tol HH, Kidd KK, Livak KJ (1993): A hypervariable segment in the human dopamine receptor $\mathrm{D}_{4}$ (DRD4) gene. Hum Mol Genet 2:767-773

Lidsky TI, Yablonsky-Alter E, Zuck L, Banerjee SP (1993): Antiglutamatergic effects of clozapine. Neurosci Lett 163: $155-158$

Lieberman J, Johns C, Pollack S (1991): Effects of clozapine on amine metabolites in cerebrospinal fluid of schizophrenic patients. In Tamminga CA, Schultz SC (eds), Schizophrenia Research. New York, Raven Press, pp 341-349

Lieberman JA, Kane JM, Johns CA (1989): Clozapine: Guidelines for clinical management. J Clin Psychiatry 50:329338

Lindström LH (1988): The effect of long-term treatment with clozapine in schizophrenia: A retrospective study in 96 patients treated with clozapine for up to 13 years. Acta Psychiatr Scand 77:524-529

Lindström LH, Widerlov E, Bissette G, Nemeroff CB (1988): Reduced CSF neurotensin concentration in drug-free schizophrenic patients. Schizophr Res 1:55-59

Lipska BK, Jaskiw GE, Chrapusta S, Karoum F, Weinberger DR (1992): Ibotenic acid lesion of the ventral hippocampus differentially affects dopamine and its metabolites in the nucleus accumbens and prefrontal cortex in the rat. Brain Res 585:1-6

Lovenberg TW, Erlander MG, Baron MG, Racke M, Slone AL, Siegel BW, Craft CM, Burns JE, Danielson PE, Sutcliffe JG (1993): Molecular cloning and functional expression of 5-HT1E-like rat and human 5-hydroxytryptamine receptor genes. Proc Natl Acad Sci USA 90:2,184-2,188

Mack KJ, Todd RD, O'Malley KL (1991): The mouse dopamine $D_{2} A$ receptor gene: Sequence homology with the rat and human genes and expression of alternative transcripts. J Neurochem 57:795-801

MacKay AP, Iversen LL, Rossor M, Spokes E, Bird E, Arregui A, Creese I, Snyder SH (1982): Increased brain dopamine and dopamine receptors in schizophrenia. Arch Gen Psychiatry 39:991-997 
Maidment NT, Marsden C (1987): Acute administration of clozapine, thioridazine and metoclopramide increases extracellular DOPAC and decreases extracellular 5-HIAA, measured in the nucleus accumbens and striatum of the rat using in vivo voltammetry. Neuropharmacology 26: 187-193

Maj J, Mogilnicka E, Przewlocka B (1975): Antagonistic effect of cyproheptadine on neuroleptic-induced catalepsy. Pharmacol Biochem Behav 3:25-27

Manberg PJ, Nemeroff CB, Bissette G, Prange AJ Jr, Gerner RH (1983): Cerebrospinal fluid levels of neurotensin-like immunoreactivity in normal controls and in patients with affective disorder, anorexia nervosa and premenstrual syndrome. Soc Neurosci Abstr 9:1054

Mansour A, Meador-Woodruff JH, Bunzow JR, Civelli.O, Akil $\mathrm{H}$, Watson SJ (1990): Localization of dopamine $\mathrm{D}_{2}$ receptor messenger-RNA and $D_{1}$ and $D_{2}$ receptor binding in the rat brain striatum and pituitary an in situ hybridization receptor. J Neurosci 10:2,587-2,600

Mansour A, Meador-Woodruff JH, Bunzow JR, Akil H, Van Tol HHM, Civelli O, Watson SJ (1991): Differential distribution of $D_{2}$ and $D_{4}$ dopamine receptor mRNAs in the rat brain: An in situ hybridization study. Soc Neurosci Abstr 17:599

Mao CC, Cheney DL, Marco E, Revuelta A, Costa E (1977): Turnover times of gamma-aminobutyric acid and acetylcholine in nucleus caudatus, nucleus accumbens, globus pallidus and substantia nigra: Effects of repeated administration of haloperidol. Brain Res 132:375-379

Marco E, Mao CC, Cheney DL, Revuelta A, Costa E (1976): The effects of antipsychotics on the turnover rate of GABA and acetylcholine in rat brain nuclei. Nature 264:363-365

Markstein R (1986): Pharmacological characterization of dopamine receptors using functional criteria. In Winlow $W$, Markstein R (eds), Neurobiology of Dopamine Systems. Manchester, University Press, pp 40-52

Martin WR, Eades CG, Thompson JA, Huppler RE, Gilbert PE (1976): The effects of morphine- and nalorphine-like drugs in the non-dependent and morphine-dependent chronic spinal dog. J Pharmacol Exp Ther 197:517-532

Mason SL, Reynolds GP (1992): Clozapine has sub-micromolar affinity for 5-HT1a receptors in human brain tissue. Eur J Pharmacol 221:397-398

Matsubara S, Matsubara R, Kusumi I, Koyama T, Yamashita I (1993): Dopamine $D_{1}, D_{2}$ and serotonin 2 receptor occupation by typical and atypical antipsychotic drugs in vivo. J Pharmacol Exp Ther 265:498-508

Matsubara S, Meltzer HY (1989): Effect of typical and atypical antipsychotic drugs on 5-HT2 receptor density in rat cerebral cortex. Life Sci 45:1,397-1,406

McPherson SE, Loo P, Braunwalder A, Wood PL (1987): Enhancement of the in vivo binding of ${ }^{3} \mathrm{H}$-flunitrazepam by the atypical neuroleptic, clozapine. Neuropharmacology 26:265-269

Meador-Woodruff JH, Mansour A, Bunzow JR, Van Tol HHM, Watson SJ Jr, Civelli O (1989): Distribution of $\mathrm{D}_{2}$ dopamine receptor mRNA in rat brain. Proc Natl Acad Sci USA $86: 7,625-7,628$

Meador-Woodruff JH, Mansour A, Work C, Van Tol HHM, Grandy D, Civelli O, Watson SJ (1991): Localization of
$D_{4}$ and $D_{5}$ dopamine receptor mRNAs in the human brain. Soc Neurosci Abstr 17:599

Meador-Woodruff JH, Mansour A, Grandy DK, Damask SP, Civelli O, Watson SJ Jr (1992): Distribution of $D_{5}$ dopamine receptor mRNA in rat brain. Neurosci Lett 145 : 209-212

Meltzer HY (1989): Clinical studies on the mechanism of action of clozapine: The dopamine-serotonin hypothesis of schizophrenia. Psychopharmacology 99:S18-S27

Meltzer HY (1991a): The mechanism of action of novel antipsychotic drugs. Schizophr Bull 17:263-287

Meltzer HY (1991b): Studies of ondansetron in schizophrenia. In Racagni G, Brunello N, Fukuda T (eds), Biological Psychiatry. Excerpta Medica vol 2, pp 891-893

Meltzer HY, Chai BL, Thompson PA, Yamamoto BK (1994): Effect of scopolamine on the efflux of dopamine and its metabolites after clozapine, haloperidol, or thioridazine. J Pharmacol Exp Ther 268:1,452-1,461

Meltzer HY, Daniels S, Fang VS (1975): Clozapine increases rat serum prolactin levels. Life Sci 17:339-342

Meltzer HY, Gudelsky GA (1992): Dopaminergic and serotonergic effects of clozapine. Implication for a unique clinical profile. Arzneimittel-Forsch Drug Res 42:268-272

Meltzer HY, Matsubara S, Lee JC (1989): Classification of typical and atypical antipsychotic drugs on the basis of dopamine $D_{1}, D_{2}$ and serotonin $2 \mathrm{pK}$ values. J Pharmacol Exper Ther 251:238-246

Meltzer HY, Nash JF (1991): Effects of antipsychotic drugs on serotonin receptors. Pharmacol Rev 43:587-604

Meltzer LT, Christoffersen CL, Serpa KA, Pugsley TA, Razmpour A, Heffner TG (1992): Lack of involvement of haloperidol-sensitive sigma binding sites in modulation of dopamine neuronal activity and induction of dystonias by antipsychotic drugs. Neuropharmacology 31 : 961-967

Mengod G, Martinez-Mir MI, Vilaro' MT, Palacios JM (1989): Localization of the mRNA for the dopamine $\mathrm{D}_{2}$ receptor in the rat brain by in situ hybridization histochemistry. Proc Natl Acad Sci USA 86:8,560-8,564

Mengod G, Nguyen H, Le H, Waeber C, Lobbert H, Palacios JM (1990): The distribution and cellular localization of the serotonin 1c receptor $\mathrm{mRNA}$ in the rodent brain examined by in situ hybridization histochemistry. Comparison with receptor binding distribution. Neuroscience 35:577-591

Mengod G, Vilaro MT, Niznik HB, Sunahara RK, Seeman P, O'Dowd BF, Palacios JM (1991): Visualization of a dopamine $D_{1}$ receptor $m R N A$ in human and rat brain. Brain Res 10:185-191

Merchant KM, Miller MA, Ashleigh EA, Dorsa DM (1991): Haloperidol rapidly increases the number of neurotensin mRNA-expressing neurons in neostriatum of the rat brain. Brain Res 540:311-314

Merchant KM, Dorsa DM (1993): Differential induction of neurotensin and c-fos gene expression by typical versus atypical antipsychotics. Proc Natl Acad Sci USA 90:3,4473,451

Meyerhof W, Obermuller F, Fehr S, Richter D (1993): A novel rat serotonin receptor: Primary structure, pharmacology 
and expression pattern in distinct brain regions. DNA Cell Biol 12:401-409

Miller JC, Wang Y, Filer D (1990): Identification by sequence analysis of a 2 nd rat brain cDNA encoding the dopamine $\left(D_{2}\right)$ receptor. Biochem Biophys Res Commun 166:109112

Miller RJ, Hiley CR (1974): Antimuscarinic properties of neuroleptics and drug-induced parkinsonism. Nature 248: 596-597

Miller RJ, Hiley CR (1976): Anti-dopaminergic and antimuscarinic effects of dibenzodiazepines: Relationship to drug-induced parkinsonism. Naunyn-Schmiedeberg's Arch Pharmacol 292:289-293

Mita T, Hanada S, Nishino N, Kuno T, Nakai H, Yamadori T, Mizoi Y, Tanaka C (1986): Decreased serotonin S2 and increased dopamine $\mathrm{D}_{2}$ in chronic schizophrenics. Biol Psychiatry 21:1,407-1,414

Mitchell PR, Doggett NS (1980): Modulation of striatal [3H]glutamic acid release by dopaminergic drugs. Life Sci 26 : 2,073-2,081

Moghaddam B, Bunney BS (1990): Acute effects of typical and atypical antipsychotic drugs on the release of dopamine from prefrontal cortex, nucleus accumbens and striatum of the rat: An in vivo microdialysis study. J Neurochem $54: 1,755-1,760$

Molineaux SA, Jessell TM, Axel R, Julius D (1989): 5-HT1C receptor is a prominent serotonin receptor subtype in the central nervous system. Proc Natl Acad Sci USA 86: 6,793-6,797

Monnet FP, Debonnel G, de Montigny C (1992): In vivo electrophysiological evidence for a selective modulation of $\mathrm{N}$-methyl-D-aspartate-induced neuronal activation in rat CA3 dorsal hippocampus by sigma ligands. J Pharmacol Exp Ther 261:123-130

Monsma FJ Jr, Mahan LC, McVittie LD, Gerfen CR, Sibley DR (1990): Molecular cloning and expression of a $D_{1}$ dopamine receptor linked to adenylyl cyclase activation. Proc Natl Acad Sci USA 87:6,723-6,727

Monsma FJ Jr, McVittie LD, Gerfen CR, Mahan LC, Sibley DR (1989): Multiple $D_{2}$ dopamine receptors produced by alternative RNA splicing. Nature 342:926-929

Monsma FJ, Shen Y, Ward RP, Hamblin MW, Sibley DR (1993): Cloning and expression of a novel serotonin receptor with high affinity for tricyclic psychotropic drugs. Mol Pharmacol 43:320-327

Montmayeur JP, Bausero P, Amlaiky N, Maroteaux L, Hen $R$, Borelli E (1991): Differential expression of the mouse $\mathrm{D}_{2}$ dopamine receptor isoforms. FEBS Lett 278:239-243

Murray AM, Waddington JL (1990): The interaction of clozapine with dopamine $D_{1}$ versus dopamine $D_{2}$ receptormediated function: Behavioural indices. Eur J Pharmacol 186:79-86

Najlerahim A, Barton AJL, Harrison PJ, Heffernan J, Pearson RCA (1989): Messenger-RNA encoding the $D_{2}-$ dopaminergic receptor detected by in situ hybridization histochemistry in rat brain. FEBS Lett 255:335-339

Nash JF, Meltzer HY, Gudelsky GA (1988): Antagonism of serotonin receptor mediated neuroendocrine and temperature responses by atypical neuroleptics in the rat. Eur J Pharmacol 151:463-468
Nasrallah HA, Jacoby CG, McCalley-Whitters M, Kuperman $S$ (1982): Cerebral ventricular enlargement in subtypes of chronic schizophrenia. Arch Gen Psychiatry 39:774777

Nemeroff CB, Youngblood W, Manberg PJ, Prange AJ Jr, Kizer JS (1983): Regional brain concentrations of neuropeptides in Huntington's chorea and schizophrenia. Science 221:972-975

Neve K, Henningsen RA, Bunzow JR, Civelli O (1989): Functional characterization of a rat dopamine $D_{2}$ receptor cDNA expressed in a mammalian cell line. Mol Pharmacol 36:446-451

Nishikawa T, Takashima M, Toru M (1983): Increased ( $\left.{ }^{3} \mathrm{H}\right)$ kainic acid binding in the prefrontal cortex in schizophrenia. Neurosci Lett 40:245-250

Nordström AL, Farde L, Halldin C (1993): High 5-HT2 receptor occupancy in clozapine treated patients demonstrated by PET. Psychopharmacology 110:365-367

Nyback H, Wiesel FA, Berggren BM, Hindmarsh T (1982): Computed tomography of the brain in patients with acute psychosis and in health volunteers. Acta Psychiatr Scand 65:403-414

Nylander I, Terenius L (1986): Chronic haloperidol and clozapine differentially affect dynorphin peptides and substance $P$ in basal ganglia of the rat. Brain Res 380:34-41

O'Dell S, La Hoste GJ, Widmark CB, Shapiro RM, Potkin SG, Marshall JF (1990): Chronic treatment with clozapine or haloperidol differentially regulates dopamine and serotonin receptors in rat brain. Synapse 6:146-153

O'Dowd BF, Nguyen T, Tirpak A, Jarvie KR, Israel Y, Seeman P, Niznik HB (1990): Cloning of two additional catecholamine receptors from rat brain. FEBS Lett 262:8-12

O'Malley KL, Mack KJ, Gandelman KY, Todd RD (1990): Organization and expression of the rat $D_{2} A$ receptor gene: Identification of alternative transcripts and a variant donor splice site. Biochemistry 29:1,367-1,371

Owen F, Cross AJ, Crow TJ, Lofthouse R, Poulter M (1981): Neurotransmitter receptors in brain in schizophrenia. Acta Psychiatr Scand 63:20-27

Owen F, Crow T], Poulter M, Cross AJ, Longden A, Riley GJ (1978): Increased dopamine-receptor sensitivity in schizophrenia. Lancet 2:223-225

Owens DG, Johnstone EC, Crow TJ, Frith CD, Jagoe JR, Kreel $\mathrm{L}$ (1985): Lateral ventricular size in schizophrenia: relationship to the disease process and its clinical manifestations. Psychol Med 15:27-41

Perry PJ, Miller DD, Arndt SV, Cadoret RJ (1991): Clozapine and norclozapine plasma concentrations and clinical response of treatment-refractory schizophrenic patients. Am J Psychiatry 148:231-235

Perry TL (1982): Normal cerebrospinal fluid and brain glutamate levels in schizophrenia do not support the hypothesis of glutamatergic neuronal dysfunction. Neurosc Lett 28:81-85

Perry TL, Buchanan J, Kish S, Hausen S (1979): Gammaaminobutyric acid deficiency in brain of schizophrenic patients. Lancet I:237-239

Plassat JL, Amlaiky N, Hen R (1993): Molecular cloning of a mammalian serotonin receptor that activates adenylyl cyclase. Mol Pharmacol 44:229-236 
Potkin SG, Bera R, Gulasekram B, Jin Y, Costa J, Gerber B, Richmond G, Ploszaj D, Carreon D, Cooper T, Stanggan K (1993): Plasma clozapine concentrations associated with clinical efficacy. Biol Psychiatry 33 (suppl.):129A

Racagni G, Cheney DL, Trabucchi M, Costa E (1976): In vivo actions of clozapine and haloperidol on the turnover rate of acetylcholine in rat striatum. J Pharmacol Exp Ther 196:323-332

Ramirez OA, Wang RY (1986): Locus coeruleus norepinephrine-containing neurons: Effects produced by acute and subchronic treatment with antipsychotic drugs and amphetamine. Brain Res 362:165-170

Rao DD, McKelvy J, Kebabian J, MacKenzie RG (1990): Two forms of the rat $D_{2}$ dopamine receptor as revealed by polymerase chain reaction. FEBS Lett 263:18-22

Rao TS, Kim HS, Lehmann J, Martin LL, Wood PL (1990): Interaction of phencyclidine receptor agonist MK-801 with dopaminergic system: Regional studies in the rat. J Neurochem 57:1,157-1,162

Rasmussen K, Aghajanian GK (1988): Potency of antipsychotics in reversing the effects of a hallucinogenic drug on locus coeruleus neurons correlates with 5-HT2 binding affinity. Neuropsychopharmacology 1:101-107

Reynolds GP, Czudek C, Andrews HA (1990): Deficit and hemispheric asymmetry of GABA uptake sites in the hippocampus in schizophrenia. Biol Psychiatry 27:1,0381,044

Reynolds GP, Rossor M, Iversen LL (1983): Preliminary studies of human cortical $5-\mathrm{HT}_{2}$ receptors and their involvement in schizophrenia and neuroleptic drug action. J Neural Transm 18 (suppl.):273-277

Reynolds GP, Stroud D (1993): Hippocampal benzodiazepine receptors in schizophrenia. J Neural Transm (Gen Sect) 93:151-155

Richelson E (1984): Neuroleptic affinities for human brain receptors and their use in predicting adverse effects. J Clin Psychiatry 45:331-336

Riederer P, Lange KW, Kornhuber J, Danielczyk W (1991): Pharmacotoxic psychosis after memantine in Parkinson's disease. Lancet 338:1,022-1,023

Roberts E (1972): Prospects for research on schizophrenia: An hypothesis suggesting that there is a defect in the GABA system in schizophrenia. Neurosci Res Program Bull $10: 468-482$

Roberts PJ, Anderson SD (1979): Stimulatory effect of L-glutamate and related amino acids on ${ }^{3} \mathrm{H}$-dopamine release from rat striatum: An in vitro model for glutamate actions. J Neurochem 32:1,539-1,545

Roberts PJ, McBean GJ, Sharif NA, Thomas EM (1982): Striatal glutamatergic function: Modifications following specific lesions. Brain Res 235:83-91

Robertson GS, Robertson HA (1986): Synergistic effects of $\mathrm{D}_{1}$ and $\mathrm{D}_{2}$ dopamine agonists on turning behaviour in rats. Brain Res 384:387-390

Rosengarten H, Schweitzer JW, Friedhoff AJ (1983): Induction of oral dyskinesias in naive rats by $D_{1}$ stimulation. Life Sci 33:2,479-2,482

Rosenthaler J, Nimmerfall F, Munzer H (1977): Nonequilibrium method for the radioimmunoassay of cloza- pine in the presence of metabolites. Eur J Biochem 80:603-609

Roth B, Ciaranello RD, Meltzer HY (1992): Binding of typical and atypical antipsychotic agents to transiently expressed 5-HT1C receptors. J Pharmacol Exp Ther 260:1,361-1,365

Roth BL, Craigo SC, Choudhary MS, Uluer A, Monsma FJ Jr, Shen Y, Meltzer HY, Sibley DR (1994): Binding of typical and atypical antipsychotic agents to 5-hydroxytryptamine- 6 and 5-hydroxytryptamine-7 receptors. J Pharmacol Exp Ther 268:1,403-1,410

Roth RH, Wolf ME, Deutch AY (1987): Neurochemistry of midbrain dopamine systems. In Meltzer HY (ed), Psychopharmacology: The Third Generation of Progress. New York, Raven Press, pp 81-95

Rothman S (1988): Non-competitive N-methyl-D-aspartate antagonists affect multiple ionic currents. J Pharmacol Exp Ther 246:137-142

Rowlands GJ, Roberts PJ (1980): Activation of dopamine receptors inhibits calcium-dependent glutamate release corticostriatal terminals in vitro. Eur J Pharmacol 62:239-242

Ruat M, Traiffort E, Arrang JM, Tardivel-lacombe J, Diaz J, Leurs R, Schwartz JC (1993a): A novel rat serotonin (5-HT6) receptor-molecular cloning, localization, and stimulation of cAMP accumulation. Biochem Biophys Res Commun 193:268-276

Ruat M, Traiffort E, Leurs R, Tardivel-Iacombe J, Diaz J, Arrang JM, Schwartz JC (1993b): Molecular cloning, characterization and localization of a high affinity serotonin receptor (5-HT7) activating cAMP formation. Proc Natl Acad Sci 90:8,547-8,551

Rubin P, Holm S, Friberg L, Videbech P, Andersen HS, Bendsen BB, Stromso N, Larsen JK, Lassen NA, Hemmingsen R (1991): Altered modulation of prefrontal and subcortical brain activity in novel diagnosed schizophrenia and schizophreniform disorder: A regional cerebral blood flow study. Arch Gen Psychiatry 48:987-995

Rubin P, Karle A, Moller-Madsen S, Hertel C, Povlsen UJ, Noring U, Hemmingsen R (1993): Computerized tomography in newly diagnosed schizophrenia and schizophreniform disorder. A controlled double blind study. Br J Psychiatry 163:604-612

Rubinstein JE, Hitzemann RJ, Ashby CR Jr, Wang RY (1989): Long-term treatment with antipsychotics does not alter the phosphoinositide response to muscarinic or $\mathrm{D}_{2}$ dopaminergic agonists in rat striatum. Brain Res 496: 385-388

Rupniak NMJ, Hall M, Mann S, Fleminger S, Kilpatrick G, Jenner P, Marsden D (1985): Chronic treatment with clozapine, unlike haloperidol, does not induce changes in striatal $\mathrm{D}_{2}$ receptor function in the rat. Biochem Pharmacol $34: 2,755-2,763$

Salin P, Mecugliano M, Cheselet MF (1990): Differential effects of chronic treatment with haloperidol and clozapine on the level of pre-pro-somatostatin mRNA in the striatum, nucleus accumbens, and frontal cortex of the rat. Cell Mol Neurobiol 10:127-143

Saller CF, Czupryna MJ, Salama AI (1990): 5-HT2 receptor blockade by ICl 169369 and other 5-HT2 antagonists modulates the effects of $\mathrm{D}_{2}$ dopamine receptor blockade. J Pharmacol Exp Ther 253:1,162-1,170 
Sanger DJ (1985): The effects of clozapine on shuttle-box avoidance responding in rats: Comparisons with haloperidol and chlordiazepoxide. Pharmacol Biochem Behav 23: 231-236

Sayers AC, Amsler HA (1977): Clozapine. In Goldberg ME (ed), Pharmacological and Biochemical Properties of Drug Substances. Am Pharmaceut Assn Acad Pharmaceut Sci, vol 1, pp 1-31

Scheibel AB, Kovelman JA (1981): Disorientation of the hippocampal pyramidal cell and its processes in the schizophrenic patient. Biol Psychiatry 16:101-102

Schmidt WJ, Krahling H, Ruhland M (1991): Antagonism of AP-5-induced sniffing stereotypy links Umespirone to atypical antipsychotics. Life Sci 48:499-505

Schmutz J (1975): Neuroleptic piperazinyl-dibenzo-azepines Drug Res 25:712-720

Schmutz J, Eichenberger E (1992): In Pindra JS, Lednicer D (eds), Chronicles of Drug Discovery. New York, John Wiley and Sons, vol 1, pp 39-59

Schulsinger F, Parnas J, Petersen ET, Schulsinger H, Teasdale TW, Mednick SA, Moller L, Silverton L (1984): Cerebral ventricular size in the offspring of schizophrenic mothers. A preliminary study. Arch Gen Psychiatry 41:602-606

Schulz SC, Koller MM, Kishore PR, Hamer RM, Gehl JJ, Friedel RO (1983): Ventricular enlargement in teenage patients with schizophrenia spectrum disorder. Am J Psychiatry 140:1,592-1,595

Schwarcz R, Creese I, Coyle JT, Snyder SH (1978): Dopamine receptors localized on cerebral cortical afferents to rat corpus striatum. Nature 271:766-768

Schwartz WJ, Krahling H, Ruhland M (1987): Antagonism of AP-5- and amphetamine-induced behaviour by timelotem as compared with clozapine and haloperidol. Life Sci 41:1,909-1,914

Scottish Schizophrenia Research Group, MacDonald HL, Best JJK (1989): The Scottish first episode schizophrenia study: Computed brain scan in patients and controls. Br J Psychiatry 154:492-498

Seabrook GR, Patel S, Marwood R, Emms F, Knowles MR, Freedman SB, McAllister G (1992): Stable expression of human $\mathrm{D}_{3}$ dopamine receptors in $\mathrm{GH} 4 \mathrm{C} 1$ pituitary cells. FEBS Lett 312:123-126

Sedvall G (1992): The current status of PET scanning with respect to schizophrenia. Neuropsychopharmacology 7:41-54

Sedvall G (1993): Brain imaging and the treatment of mental disorders. In Mendlewicz J, Brunello N, Langer SZ, Racagni G (eds), New Pharmacological Approaches to the Therapy of Depressive Disorders. Int Acad Biomed Drug Res, vol. 5, Basel, Karger, pp 176-183

Seeman $P$ (1992): Dopamine receptor sequences. Therapeutic levels of neuroleptics occupy $\mathrm{D}_{2}$-receptors, clozapine occupies $\mathrm{D}_{4}$. Neuropsychopharmacology 7:261-284

Seeman P, Bzowej NH, Guan HC, Bergeron C, Reynolds GP, Bird ED, Riederer $P$, Jellinger K, Watanabe $S$, Tourtellotte WW (1987): Human brain $D_{1}$ and $D_{2}$ receptors in schizophrenia, Alzheimer's, Parkinson's, and Huntington's diseases. Neuropsychopharmacology 1:5-15

Seeman P, Guan HG, Van Tol HHM (1993): Dopamine D4 receptors elevated in schizophrenia. Nature 365:441-445
Seeman P, Lee T, Chau-Wong M, Wong K (1976): Antipsychotic drug doses and neuroleptic/dopamine receptors. Nature 261:717-719

Seeman P, Niznik HB, Guan HG, Booth G, Ulpian C (1989): Link between $D_{1}$ and $D_{2}$ dopamine receptors is reduced in schizophrenia and Huntington diseased brain. Proc Natl Acad Sci 86:10,156-10,160

Seeman P, Van Tol HHM (1994): Dopamine receptor pharmacology. Trends Pharmacol Sci 15:264-270

Selbie LA, Hayes G, Shine J (1989): The major dopamine $D_{2}$ receptor. Molecular analysis of human D2A-subtype. DNA 8:683-689

Sesack SR, Deutch AY, Roth RH, Bunney BS (1989): Topographical organization of the efferent projections of the medial prefrontal cortex in the rat: An anterograde tracttracing study with Phaseolus vulgaris leucoagglutinin. J Comp Neurol 290:213-242

Sesack SR, Pickel VM (1990): In the rat medial nucleus accumbens, hippocampal and catecholaminergic terminals converge on spiny neurons and are in apposition to each other. Brain Res 527:266-279

Shaikh S, Collier D, Kerwin RW, Pilowsky LS, Gill M, Zu WM, Thornton A (1993): Dopamine $\mathrm{D}_{4}$ receptor subtypes and response to clozapine. Lancet 341:116

Shelton RC, Weinberger DR (1986): X-ray computerized tomography studies in schizophrenia: A review and synthesis. Nasrallah HA, Weinberger DR (eds), The Neurology of Schizophrenia. Handbook of Schizophrenia. Amsterdam, Elsevier, vol 1, pp. 207-250

Shen Y, Monsma FJ Jr, Metcalf MA, Jose PA, Hamblin MW, Sibley DR (1993): Molecular cloning and expression of a 5-hydroxytryptamine-7 serotonin receptor subtype. J Biol Chem 268:18,200-18,204

Sherman AD, Hegwood TS, Baruah S, Waziri R (1991): Deficient NMDA-mediated glutamate release from synaptosomes of schizophrenics. Biol Psychiatry 30:1,1911,198

Simon H, Taghzouti K, Gozlan H, Studler JM, Louilot A, Herve D, Glowinski J, Tassin JP, LeMoal M (1988): Lesion of dopaminergic terminals in the amygdala produces enhanced locomotor response to $\mathrm{D}$-amphetamine and opposite changes in dopaminergic activity in prefrontal cortex and nucleus accumbens. Brain Res 447:335-340

Simpson MDC, Slater P, Deakin JFW, Royston MC, Skan WJ (1990): Reduced GABA uptake sites in the temporal lobe in schizophrenia. Neurosci Lett 107:211-215

Simpson MDC, Slater P, Royston MC, Deakin JFW (1992): Alterations in phencyclidine and sigma binding sites in schizophrenic brains: Effects of disease process and neuroleptic medication. Schizophr Res 6:41-48

Singh MM, Kay SR (1979): Therapeutic antagonism between anticholinegic anti-Parkinsonian agents and neuroleptics in schizophrenia: Implications for a neuropharmacological model. Neuropsychobiology 5:74-86

Sokoloff P, Andrieux M, Besancon R, Pilon C, Martres MP, Giros B, Schwartz JC (1992a): Pharmacology of human dopamine $\mathrm{D}_{3}$ receptor expressed in a mammalian cell line: Comparison with $\mathrm{D}_{2}$ receptor. Eur J Pharmacol 225:331-337

Sokoloff P, Giros B, Martres MP, Bouthenet ML, Schwartz JC (1990): Molecular cloning and characterization of a 
novel dopamine receptor $\left(\mathrm{D}_{3}\right)$ as a target for neuroleptics. Nature 347:146-151

Sokoloff P, Martres MP, Giros B, Bouthenet ML, Schwartz JC (1992b): The third dopamine receptor $\left(D_{3}\right)$ as a novel target for antipsychotics. Biochem Pharmacol 43:659-666

Sommermeyer H, Dompert WU, Glaser T (1993): Signalling via rat dopamine $D_{2}$ receptors expressed in mouse fibroblast is not influenced by compounds binding to the sigma sites of these cells. Cell Signalling 5:747-752

Spokes EGS, Garret NJ, Rossor MN, Iversen LL (1980): Distribution of GABA in post-mortem brain tissue from control, psychotic, and Huntington's chorea subjects. J Neurol Science 48:303-313

Squires RF, Lajtha A, Saederup E, Palkovits M (1993): Reduced $\left({ }^{3} \mathrm{H}\right)$ flunitrazepam binding in cingulate cortex and hippocampus of postmortem schizophrenic brains: Is selective loss of glutamatergic neurons associated with major psychoses? Neurochem Res 18:219-223

Starle L, Collin AK, Ungerstedt U (1990): Effect of halothane anaesthesia on extracellular levels of dopamine, dihydroxyphenylacetic acid, homovanillic acid in rat striatum: A microdialysis study. Naunyn-Schmiedeberg's Arch Pharmacol 342:136-140

Stille G, Lauener H, Eichenberger E (1971): The pharmacology of 8-chloro-11-(4-methyl-1-piperazinyl)-5H-dibenzo $[\mathrm{b}, \mathrm{e}][1,4]$ diazepine (Clozapine). II Farmaco 26:603-625

Stockmeier CA, DiCarlo JJ, Zhang Y, Thompson P, Meltzer HY (1993): Characterization of typical and atypical antipsychotic drugs based on in vivo occupancy of serotonin 2 and dopamine ${ }_{2}$ receptors. J Pharmacol Exp Ther 266: $1,374-1,384$

Stoof JC, Kebabian JW (1981): Opposing roles for $\mathrm{D}_{1}$ and $\mathrm{D}_{2}$ dopamine receptors in efflux of cyclic AMP from neostriatum. Nature 294:366-368

Stormann TM, Gdula DC, Weiner DM, Brann MR (1990): Molecular cloning and expression of a dopamine $\mathrm{D}_{2}$ receptor from human retina. Mol Pharmacol 37:1-6

Stowe ZN, Nemeroff CB (1993): Non-dopaminergic mechanisms relevant to antipsychotic activity. In Brunello $\mathrm{N}$, Mendlewicz J, Racagni G (eds), New Generation of Antipsychotic Drugs: Novel Mechanisms of Action. Int Acad Biomed Res, vol 4, Basel, Karger, pp 15-26

Strader C, Sigal IS, Dixon RAF (1989): Structural basis of betaadrenergic receptor function. FASEB J 3:1,825-1,832

Strange PG (1994): Dopamine $D_{4}$ receptors: Curiouser and curiouser. Trends Pharmacol Sci 15:317-319

Suddath RL, Casanova MF, Goldberg TE, Daniel DG, Kelsoe JR, Weinberger DR (1989): Temporal-lobe pathology in schizophrenia: A quantitative magnetic-resonance imaging study. Am J Psychiatry 146:464-472

Suddath RL, Christison GW, Torrey EF, Casanova MF, Weinberger DR (1990): Anatomical abnormalities in the brains of monozygotic twins discordant for schizophrenia. $\mathrm{N}$ Engl J Med 322:789-794

Sunahara RK, Guan HC, O'Dowd BF, Seeman P, Laurier LG, Ng G, George SR, Torchia J, Van Tol HHM, Niznik HB (1991): Cloning of the gene for a human dopamine $D_{5}$ receptor with a higher affinity for dopamine than $D_{1}$. Nature 350:614-619

Sunahara RK, Niznik HB, Weiner DM, Stormann TM, Brann MR, Kennedy JL, Gelemter JE, Rozmahel R, Yang Y, Is- rael Y, Seeman P, O'Dowd BF (1990): Human dopamine $\mathrm{D}_{1}$ receptor encoded by an intronless gene on chromosome 5. Nature 347:80-83

Surmeier DJ, Reiner A, Levine MS, Ariiano MA (1993): Are neostriatal dopamine receptors co-localized? Trends Neurosci 8:299-305

Swahn C-G (1990): Determination of N-acetyl-L-aspartic acid in human cerebrospinal fluid by gas chromatographymass spectrometry. J Neurochem 54:1,584-1,588

Tamminga CA, Gerlach J (1987): New neuroleptics and experimental antipsychotics in schizophrenia. In Meltzer HY (ed), Psychopharmacology: The Third Generation of Progress. New York, Raven Press, pp. 1,129-1,140

Tatetsu S (1964): A contribution to the morphological background of schizophrenia: With special reference to the findings in the telencephalon. Acta Neuropathol (Berl) 3:558

Tiberi M, Jarvie KR, Silvia C, Falardeau P, Gingrich JA, Godinot N, Bertrand L, Yang-Feng TL, Fremeau RT, Caron MG (1991): Cloning, molecular characterization and chromosomal assignment of a gene encoding a novel $D_{1}$ dopamine receptor subtype: Differential expression pattern in rat brain compared to $\mathrm{D}_{1 \mathrm{~A}}$ receptor. Proc Natl Acad Sci USA 88:7,491-7,495

Tork I (1991): Anatomy of the serotonergic system. Ann NY Acad Sci 600:9-34

Toru M, Watanabe S, Shibuya H, Nishikawa T, Noda K, Mitsushio $\mathrm{H}$, Ichikawa $\mathrm{H}$, Kurumaji A, Takashima M, Mataga N, Ogawa A (1988): Neurotransmitter receptors and neuropeptides in post-mortem brains of chronic schizophrenic patients. Acta Psychiatr Scand 78:121-137

Uhl GR, Kuhar MJ (1984): Chronic neuroleptic treatment enhances neurotensin receptor binding in human and rat substantia nigra. Nature 309:350-352

Uhl GR, Snyder SH (1977): Regional and subcellular distribution of brain neurotensin. Life Sci 19:1,827-1,832

Uphouse L, Andrade M, Caldarola-Pastusza M, Maswood $\mathrm{S}$ (1994): Hypothalamic infusion of the $5-\mathrm{HT}_{2} / 1 \mathrm{C}$ agonist, DOI, prevents the inhibitory action of the $5-\mathrm{HT}_{1 \mathrm{~A}}$ agonist, 8-OH-DPAT, on lordosis behavior. Pharmacol Biochem Behav 47:467-470

Van Groen T, Wyss JM (1990): Extrinsic projections from area CA1 of the rat hippocampus: Olfactory, cortical, subcortical, and bilateral hippocampal formation projections. J Comp Neurol 302:515-528

Van Kammen DP (1977): Gamma aminobutyric acid (GABA) and the dopamine hypothesis of schizophrenia. Am J Psychiatry 134:138-143

Van Kammen DP, Antelman S (1984): Impaired noradrenergic transmission in schizophrenia? A mini review. Life Sci $34: 1,403-1,413$

Van Kammen DP, Peters J, van Kammen WB, Nugent A, Goetz KL, Yao J, Linnoila M (1989): CSF norepinephrine in schizophrenia is elevated prior the relapse after haloperidol withdrawal. Biol Psychiatry 26:176-188

Van Putten T, Marder SR, Wirshing WC, Aravagiri M, Chabert $N$ (1991): Neuroleptic plasma levels. Schizophrenia Bull 17:197-215

Van Tol HHM, Bunzow JR, Guan HC, Sunahara RK, Seeman P, Niznik HB, Civelli O (1991): Cloning of the gene 
for a human dopamine $\mathrm{D}_{4}$ receptor with high affinity for the antipsychotic clozapine. Nature 350:610-614

Van Tol HHM, Wu CM, Guan HC, Ohara K, Bunzow JR, Civelli O, Kennedy J, Seeman P, Niznik HB, Jovanovic $\mathrm{V}$ (1992): Multiple dopamine $\mathrm{D}_{4}$ receptor variants in the human population. Nature 358:149-152

Vartiainen H, Leinonen E, Putkonen A, Lang S, Hagert U, Tolvanen U (1993): A long-term study of remoxipride in chronic schizophrenic patients. Acta Psychiatr Scand 87:114-117

Vasse M, Protais P (1988): Increased grooming behavior is induced by apomorphine in mice treated with discriminant benzamide derivatives. Eur J Pharmacol 156: 1-11

Wadenberg ML, Ahlenius S, Svensson TH (1993): Potency mismatch for behavioral and biochemical effects by dopamine receptor antagonists: Implications for the mechanism of action of clozapine. Psychopharmacology 110: 273-279

Walaas L (1981): Biochemical evidence for overlapping neocortical and allocortical glutamate projections to the nucleus accumbens and rostral caudatoputamen in the rat brain. Neuroscience 6:399-405

Walker JM, Bowen WD, Walker FO, Matsumoto RR, De Costa B, Rice KC (1990): Sigma receptors: Biology and function. Pharmacol Rev 42:355-402

Walker JM, Matsumoto RR, Bowen WD, Gans DL, Jones KD, Walker FO (1988): Evidence for a role of haloperidolsensitive sigma-opiate receptors in the motor effects of antipsychotic drugs. Neurology 38:961-965

Wallas I, Fonnum F (1980): Biochemical evidence for glutamate as a transmitter in hippocampal efferents to the basal forebrain and hypothalamus in the rat brain. Neuroscience $5: 1,691-1,698$

Walters JR, Bergstrom DA, Carlson JH, Chase TN, Braun AR (1987): $D_{1}$ dopamine receptor activation required for postsynaptic expression of $\mathrm{D}_{2}$ agonist effects. Science 236:719-722

Wanibuchi F, Usuda S (1990): Synergistic effects between $D_{1}$ and $D_{2}$ dopamine antagonists on catalepsy in rats. Psychopharmacology 102:339-342

Watling KJ, Beer MS, Stanton JA, Newberry NR (1990): Interaction of the atypical neuroleptic clozapine with 5-HT3 receptors in the cerebral cortex and superior cervical ganglion of the rat. Eur J Pharmacol 182:465-472

Weick BG, Walters JR (1987): Effects of $D_{1}$ and $D_{2}$ dopamine receptor stimulation on the activity of substantia nigra pars reticulata neurons in 6-hydroxydopamine lesioned rats. $D_{1} / D_{2}$ coactivation induces potentiated responses. Brain Res 405:234-246

Weinberger DR (1987): Implications of normal brain development for the pathogenesis of schizophrenia. Arch Gen Psychiatry 44:660-669

Weinberger DR, Berman KF, Illowsky B (1988): Physiological dysfunction of dorsolateral prefrontal cortex in schizophrenia, III: A new cohort and evidence for a monoaminergic mechanism. Arch Gen Psychiatry 45:609-615

Weinberger DR, Berman KF, Zec RF (1986): Physiological dysfunction of dorsolateral prefrontal cortex in schizophre- nia, I: Regional cerebral blood flow (rCBF) evidence. Arch Gen Psychiatry 43:114-125

Weinberger DR, DeLisi LE, Perman GP, Targum S, Wyatt RJ (1982): Computed tomography in schizophreniform disorder and other acute psychiatric disorders. Arch Gen Psychiatry 39:778-783

Weinberger DR, Torrey EF, Neophytides AN, Wyatt RJ (1979): Lateral cerebral ventricular enlargement in chronic schizophrenia. Arch Gen Psychiatry 36:735-739

Weiner DM, Brann MR (1989): The distribution of a dopamine $D_{2}$ receptor messenger-RNA in rat brain. FEBS Lett 253:207-213

Weiner DM, Levey AI, Brann MR (1990): Expression of muscarinic acetylcholine and dopamine receptor mRNA in rat basal ganglia. Proc Natl Acad Sci USA 87:7,050-7,054

Weiner DM, Levey AI, Sunahara RK, Niznik HB, O’Dowd BF, Seeman P, Brann MR (1991): $D_{1}$ and $D_{2}$ dopamine receptor mRNA in rat brain. Proc Natl Acad Sci USA $88: 1,859-1,863$

Weinshank RL, Adham N, Macchi M, Olsen MA, Brachek TA, Hartig PR (1991): Molecular cloning and characterization of a high affinity dopamine receptor ( $\mathrm{D}_{1}$ beta) and its pseudogene. J Biol Chem 266:22,427-22,435

Widerlov E, Lindström LH, Bresev G, Manberg PJ, Nemeroff CB, Breese GR, Kizer JS, Prange AJ Jr (1982): Subnormal CSF levels of neurotensin in a subgroup of schizophrenic patients: Normalization after neuroleptic treatment. Am J Psychiatry 139:1,122-1,126

Wiley JL, Porter JH (1992): Serotonergic drugs do not substitute for clozapine in clozapine-trained rats in a two-lever drug discrimination procedure. Pharmacol Biochem Behav 43:961-965

Williams AO, Reveley MA, Kolakowska T, Ardern M, Madelbrote BM (1985): Schizophrenia with good and poor outcome. II. Cerebral ventricular size and its clinical significance. Br J Psychiatry 146:239-246

Williams TG, Murtaugh MP, Beitz AJ (1990): The effects of acute haloperidol treatment on brain proneurotensin mRNA: In situ hybridization analysis using a novel fluorescence detection procedure. Mol Brain Res 7:347 358

Wilmot CA, Szczepanik AM (1989): Effects of acute and chronic treatments with clozapine and haloperidol on serotonin (5-HT2) and dopamine $\left(\mathrm{D}_{2}\right)$ receptors in the rat brain. Brain Res 487:288-298

Winblad B, Bucht G, Gottfries CG, Roos BE (1979): Monoamines and monoamine metabolites in brain from demented schizophrenics. Acta Psychiatr Scand 60:17-28

Wolf S, Hyde TM, Weinberger DR (1993): Neurobiology of schizophrenia. Curr Opinion Neurol Neurosurg 6:86-92

Zhang J, Chiodo LA, Freeman AS (1992a): Electrophysiological effects of MK-801 on rat nigrostriatal and mesoaccumbal dopaminergic neurons. Brain Res 590:153-163

Zhang J, Chiodo LA, Freeman AS (1993): Further characterization of the effects of BMY 14802 on dopamine neuronal activity. Synapse 15:276-284

Zhang J, Chiodo LA, Wettstein JG, Junien J-L, Freeman AS (1992b): Acute effects of sigma ligands on the elec- 
trophysiological activity of rat nigrostriatal and mesoaccumbal dopaminergic neurons. Synapse 11:267-278
Cone R, Pribnow D, Salon J, Bunzow JR, Civelli O (1990): Cloning and expression of human and rat $\mathrm{D}_{1}$ dopamine receptors. Nature 347:76-80 